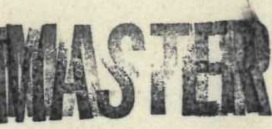

\title{
Sensitization, Intergranular Attack, Stress Corrosion Cracking, and Irradiation Effects on the Corrosion of Iron-Chromium-Nickel Alloys
}

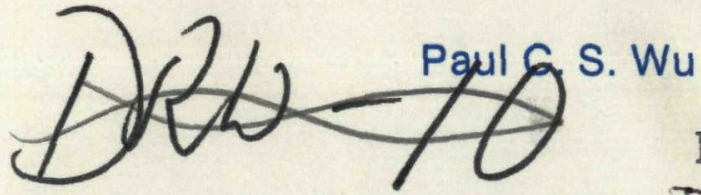

This document is PUBLICLY RELEASABLE David Hamrin, ORNL Date 2-5-2013

Any further distribution by any holder on document or of the data *herein to third parties representing foretise interests, foreign governments, foreign companies and foreign substsiaries or foreign divisions of d. companies should be coerdinated with ve Director, Division of Reactor thesearch and Development Department drEnergy. 


\section{Printed in the United States of America. Available from}

the Department of Energy,

Technical Information Center

P.O. Box 62, Oak Ridge, Tennessee 37830

Price: Printed Copy $\$ 6.50 ;$ Microfiche $\$ 3.00$

This report was prepared as an account of work sponsored by an agency of the United States Government. Neither the United States Government nor any agency thereof, nor any of their employees, contractors, subcontractors, or their employees, makes any warranty, express or implied, nor assumes any legal liability or responsibility for any third party's use or the results of such use of any information, apparatus, product or process disclosed in this report, nor represents that its use by such third party would not infringe privately owned rights. 


\section{DISCLAIMER}

This report was prepared as an account of work sponsored by an agency of the United States Government. Neither the United States Government nor any agency Thereof, nor any of their employees, makes any warranty, express or implied, or assumes any legal liability or responsibility for the accuracy, completeness, or usefulness of any information, apparatus, product, or process disclosed, or represents that its use would not infringe privately owned rights. Reference herein to any specific commercial product, process, or service by trade name, trademark, manufacturer, or otherwise does not necessarily constitute or imply its endorsement, recommendation, or favoring by the United States Government or any agency thereof. The views and opinions of authors expressed herein do not necessarily state or reflect those of the United States Government or any agency thereof. 


\section{DISCLAIMER}

Portions of this document may be illegible in electronic image products. Images are produced from the best available original document. 
ORNL/TM-6311

Dist. Category UC-79C

Contract No. W-7405-eng-26

ADVANCED FUEL RECYCLE PROGRAM

SENS ITIZATION, INTERGRANULAR ATTACK, STRESS CORROSION

CRACKING, AND IRRADIATION EFFECTS ON THE

CORROSION OF IRON-CHROMIUM-NICKEL ALLOYS

Paul C. S. Wu

Westinghouse Electric Corporation

Advanced Reactors Division

This document is

PUBLICLY RELEASABLE

David Hamrin, ORNL

Authorizing Official

Date 2-5-2013

Date Published: April 1978

This report was prepared as an account of work sponsored by the United States Govemment Netther the United States nor the United States Department of Energy, nor any of their employees, nor any of their contractors, subcontractors, or therr employees, makes any warranty, express or umplied, or assumes any legal lability or responsibulty for the accuracy, completeness or usefulness of any unformation, appasatus, product or process disclosed, or represents that its use would nor infrunge privately owned nghts

NOTICE This document contaıns information of a prelıminary nature. It is subject to revision or correction and therefore does not represent a final report.
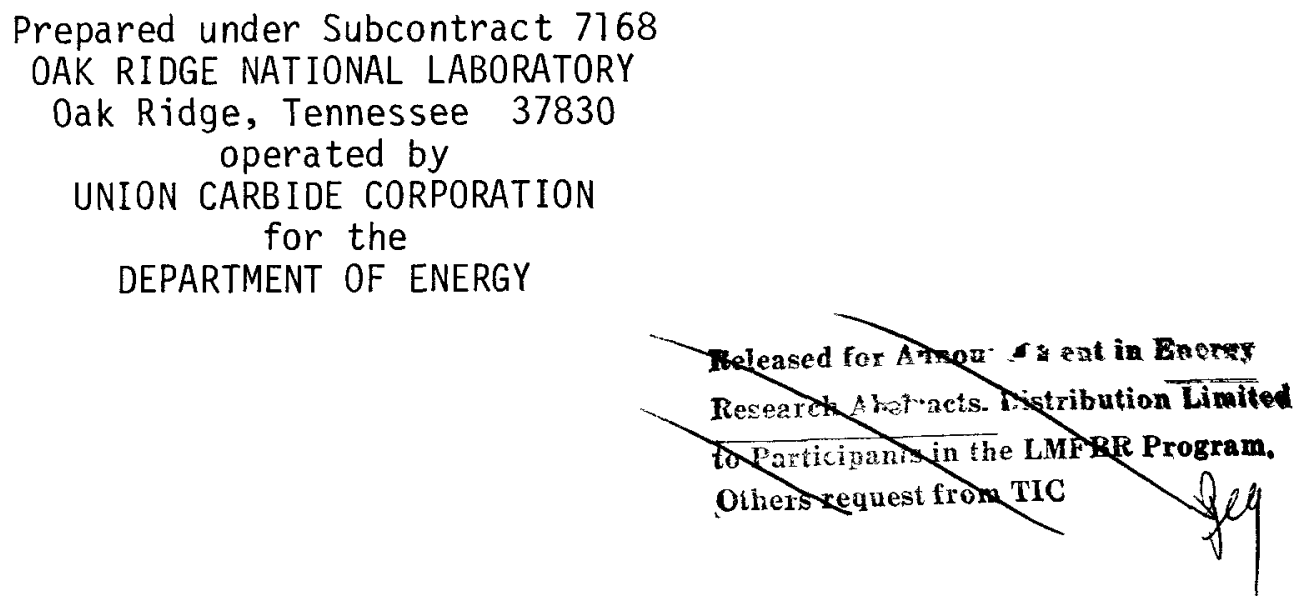


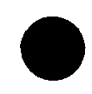

,

$-$

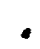

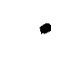

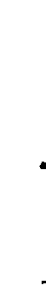

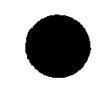




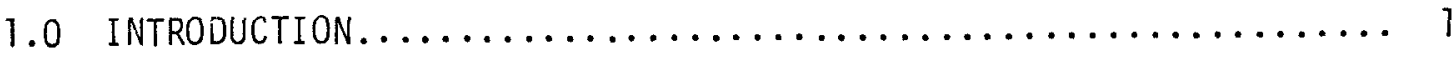

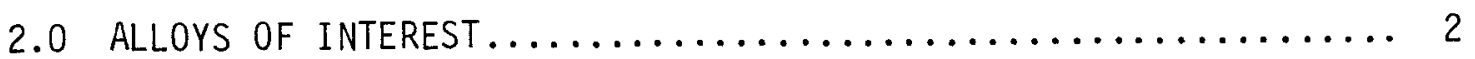

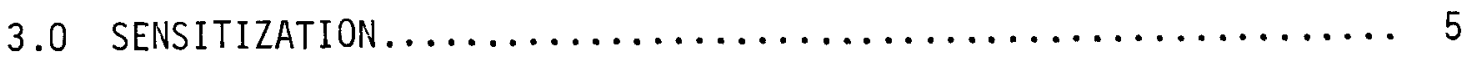

3.1 Time-Temperature-Sensitization Diagrams............ 5

3.2 Effects of Alloy Chemistry..................... 11

3.3 Effect of Cold Work......................... 14

3.4 Failure of Sensitized Nuclear Components............ 14

3.5 How to Avoid Intergranular Attack................. 15

4.0 STRESS CORROSION CRACKING $\ldots \ldots \ldots \ldots \ldots \ldots \ldots \ldots \ldots \ldots \ldots \ldots \ldots \ldots \ldots \ldots \ldots \ldots$

4.1 Stress Corrosion Cracking of $\mathrm{Fe}-\mathrm{Cr}-\mathrm{Ni}$ Alloys.......... 19

4.2 Cracking of Fe-Cr-Ni Alloys in Chloride Environments.... 20

4.2.1 Pitting of Fe-Cr-Ni Alloys in Chloride

Environment.......................... 21

4.2.2 Stress Corrosion Cracking Mechanisms for

Fe-Cr-Ni Alloys........................ 23

4.2.2.1 The Electrochemical Theory...........23

4.2.2.2 The Theory of Stress Sorption Cracking... 24

4.2.2.3 Conclusion.................... 26

4.2.3 The Effect of Stress..................... 27

4.2.4 The Effect of ChToride Ion Concentration......... 29

4.2.5 The Effect of Oxygen.................... 33

4.2.6 The Effect of $\mathrm{pH} . \ldots \ldots \ldots \ldots \ldots \ldots \ldots \ldots \ldots \ldots \ldots \ldots$ 
Page No.

4.2.7 The Effect of Temperature.............. 34

4.2.8 The Effect of Metallic Cations............ 36

4.2.9 The Effect of Alloy Composition............. 39

4.2 .10 Conclusion $\ldots \ldots \ldots \ldots \ldots \ldots \ldots \ldots \ldots \ldots \ldots \ldots$

4.3 Cracking of Fe-Cr-Ni Alloys in Fluoride Environment...... 49

4.3.1 Corrosion of $\mathrm{Fe}-\mathrm{Cr}-\mathrm{Ni}$ Alloys in $\mathrm{HNO}_{3}-\mathrm{HF}$ Solutions. 51

4.3 .2 Conclusion......................... 52

4.4 Cracking of $\mathrm{Fe}-\mathrm{Cr}$-Ni Alloys in Caustic Environment...... 52

4.4 .1 The Effect of Stress.................. 53

4.4.2 The Effect of Caustic Concentration and

Temperature......................... 53

4.4.3 The Effect of Alloy Content.............. 61

4.4.4 The Effect of Alloy Structure............. 67

4.4.5 Caustic Stress Corrosion Cracking Associated

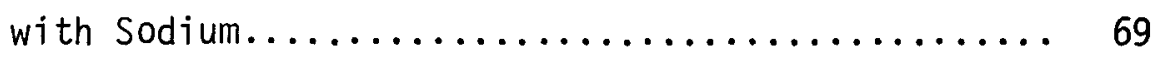

4.4 .6 Conclusion......................... 71

4.5 Overall Conclusion...................... 73

5.0 EFFECT OF RADIATION ON THE CORROSION OF STAINLESS STEEL IN AQUEOUS SOLUTION............................ 74

5.1 Radiation Effects and their Influence on Corrosion..... 75

5.1 .1 In the Metal...................... 75

5.1 .1 .1 Activity Changes.............. 76

5.1 .1 .2 Dimensional Changes............. 76

5.1.1.3 Embrittlement................. 77

5.1 .1 .4 Phase Changes................ 77 
Page No.

5.1 .2 In the Protective Layer............... 78

5.1.2.1 Effect on the Electric Field........ 78

5.1.2.2 Effect on Diffusion............ 79

5.1.2.3 Activity Changes.............. 79

5.1.2.4 Phase Changes................ 79

5.1 .3 In the Corrodant.................... 80

5.2 Effect of Radiation on the Corrosion of Stainless

Steel in Aqueous Solution................... 81

5.2.1 Effect of $\gamma$-Radiation................ 81

5.2 .2 Crevice Corrosion.................... 82

5.2 .3 Phase Changes...................... 82

5.2 .4 Nitrogen Fixation.................... 83

5.2.5 Decomposition of Carbon Dioxide........... 83

5.2 .6 Radiolysis Products................. 83

5.2.7 The Integrity of the EBR-II Fuel Pin Cladding in water............................ 84

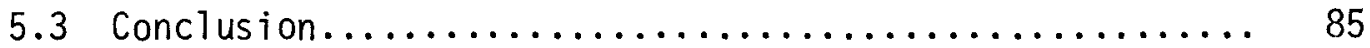

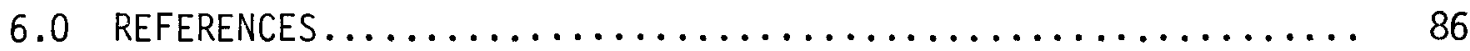




\subsection{INTRODUCTION}

A few decades ago, reported incidents of stress corrosion cracking of austenitic stainless steels were very rare. The increased use of stainless steels in the nuclear and other industries during the past twenty years has resulted in a great rise in such reports. In the current generation of water-cooled nuclear power reactor plants, the problems of stress-corrosion cracking have been mainly concerned with chloride environment. The possibilities of component failure due to chloride induced stress-corrosion cracking have stimulated considerable research activity.

Due to the use of liquid sodium as the coolant, most components of LMFBR's will not be susceptible to chloride induced stress-corrosion cracking during operation, but contamination of chloride-containing materials must be avoided during fabrication, shipping, and other stages of plant life. However, the use of liquid sodium as a heat transfer medium raises the possibility of the formation of sodium hydroxide and the subsequent danger of caustic stress-corrosion cracking of components. Unfortunately, relatively little effort has been spent in this area compared to the work conducted on chloride cracking.

In contrast to the water reactors, stress-corrosion cracking problems are concerned mainly during the storage period of the spent fuels from the sodium-cooled fast breeder reactors. To assure capability of completing the fuel cycle in a sodium-cooled fast breeder reactor economy, a comprehensive research and development program is being conducted by ERDA to address and solve the new problems introduced by LMFBR fuels. One of the major efforts involves limiting the fuel storage requirements of early commercial breeders by providing the industry with a sound and economic fuel reprocessing capability.

One immediate concern of the overal1 LMFBR fuel reprocessing technology is the problem of selecting a safe and efficient method to remove the sodium from the fuel assemblies as well as choosing a proper way of storage before the fuels are recycled. Although a sodium pool would be desirable for storing the LMFBR spent fuels, economic considerations and the fact that the present concept of LMFBR fuel reprocessing is by the aqueous 
Purex Process so that sodium must be removed, dictate the need of evaluating the feasibility of water pit storage for the LMFBR spent fuels. The objective of the present study is to conduct a literature review on sensitization, intergranular attack, and stress corrosion cracking of austenitic stainless steels with emphasis on dilute solutions at temperatures below the boiling point of water. In addition, attempt will be made to list the possible sources of contaminants during manufacture, shipping, construction and all phases of operation of the sodium containing components. The susceptibility of the different materials to stress corrosion cracking in the various contaminants will be discussed and suggestions to prevent serious problems will be made. Finally, areas of further studies to provide pertinent information for performance prediction will be outlined. The general background on radiation corrosion and its effect on stainless steels in aqueous systems are briefly discussed.

\subsection{ALLOYS OF INTEREST}

Although a great many alloys are known to suffer from stress corrosion, the materials to be considered in the present study are limited to mainly the 300-series austenitic stainless steels which are the most important structural materials for sodium-cooled fast breeder reactors. The materials and their applications in LMFBR technology are briefly listed in Table 1. Some of the information was previously reported. (1) The nickel-base alloys particularly the Alloy 718 with its excellent high temperatures strength are attractive structural materials for many components, and thus they are included in this report. The addition of the stabilized grades of 300-series austenitic stainless steel, Type 321 SS and Type 348 SS are mainly for the purpose of comparison. The nominal chemical compositions of the materials are given in Table 2 .

Materials with various thermal-mechanical histories will be discussed in the present report. The mill annealed and coarse grained structures will be present in heavy sections of reactor components while cold-worked structures will exist in the thin walled fuel claddings and ducts. However, due to the high operating temperature of the fast breeder reactors all of the 300 Series austenitic stainless steels and some of the nickel-base alloys 
will be sensitized during service. Therefore, it is important to define "sensitization" and its effect on the susceptibility of the materials to stress corrosion.

TABLE 2-1

MATERIALS FOR LMFBR COMPONENTS

Material

AISI 304

Type 308 weld metal

Type 16-8-2 weld metal

AISI 316

Inconel Alloy 600

Inconel 718

SA 508, Class II

$20 \%$ cold-worked

Type 376 SS

$2-1 / 4 \mathrm{Cr}-7 \mathrm{Mo}$
Components or Parts

Pressure vessel, thermal and neutron shields, core support, primary and secondary cold-leg piping, IHX shell, tube sheet and tubing, pumps, valves, nozz?es.

Weld filler for Type 304 SS.

Weld filler for Type 316 SS.

Nozzles, primary and secondary hot-leg piping, and upper internals. Possible replacements for 304 and 316 as piping, etc.

Possible neutron shielding

Upper internal thermal shielding, nozzle liners.

Vessel head and flange.

Fuel cladding and ducts.

Steam generator she11, tube sheets, and tubes. 
TABLE 2-2

ALLOY COMPOSITIONS FOR THE AUSTENITIC STAINLESS STEELS

\begin{tabular}{|c|c|c|c|c|c|c|c|c|c|c|}
\hline Material & $\mathrm{Fe}$ & $\mathrm{NI}$ & $\mathrm{Cr}$ & C & $\mathrm{Mn}$ & $\mathrm{S1}$ & $\mathbf{S}$ & $P$ & Mo & Other \\
\hline AISI 304 & $\mathrm{Bal}$ & $8-12$ & $18-20$ & .08 & 2.0 & 1.0 & .03 & .045 & - & \\
\hline AISI 308 weld & $\mathrm{Bal}$ & $9-11$ & $18-21$ & .08 & 2.5 & 0.9 & .03 & .04 & - & \\
\hline AISI 316 & $\mathrm{Bal}$ & $10-14$ & $16-18$ & .08 & 2.0 & 1.0 & .03 & .045 & $2.0-3.0$ & \\
\hline $\begin{array}{l}\text { Inconel } \\
\text { Alloy } 600\end{array}$ & $6-10$ & $72 \mathrm{~min}$ & $14-17$ & .15 & 1.0 & 0.5 & 0.15 & & & $\mathrm{Cu}: .5 \max$ \\
\hline $\begin{array}{l}\text { Inconel } \\
\text { Alloy } 718\end{array}$ & $\mathrm{Ba} 1$ & $50-55$ & $17-21$ & .08 & .35 & .35 & .015 & .015 & $2.8-3.3$ & $\begin{array}{l}\mathrm{Nb}: 4.75-5.5 \\
\mathrm{~T} i: .65-1.15 \\
\mathrm{~A} 1: 0.2-0.8 \\
\mathrm{Co}: 1.0 \max \\
\mathrm{B}: .006 \max \\
\mathrm{Cu}: .3 \max \end{array}$ \\
\hline $\begin{array}{l}\text { SA 508, } \\
\text { Class II }\end{array}$ & Bal. & $.50-.90$ & $.25-.45$ & $.27 \max$ & $.5-.9$ & $.15-.35$ & 5.025 & .025 & $.55-70$ & \\
\hline $2-1 / 4 \mathrm{Cr}-1 \mathrm{Mo}$ & $\mathrm{Bal}$ & -- & 2.25 & 0.15 & 0.45 & 0.5 & -- & -- & 1.0 & \\
\hline
\end{tabular}




\subsection{SENSITIZATION}

Sensitization is a terminology used to describe the precipitation of carbides at grain boundaries of alloys during high-temperature exposure. The essence of sensitization is that the rate of attack of austenitic stainless steels under intergranular attack (IGA) or stress-corrosion cracking (SCC) conditions is extremely sensitive to the carbides precipitated in the 800 to $1500^{\circ} \mathrm{F}\left(427\right.$ to $\left.815^{\circ} \mathrm{C}\right)$ temperature range. Common practice is to map the time to failure of alloys in a standardized test ${ }^{(2)}$ as a function of exposure time and temperature in the sensitizing range.

Two different models have been proposed for the mechanisms involved in intergranular attack. Strauss et al. (3) proposed a mechanism of intergranular corrosion based on the impoverishment of chromium in the grain boundaries; in supplying the chromium for the carbide precipitate, the chromium content in the immediate vicinity of these carbides drops below a critical limit, and therefore the material becomes subject to severe localized attack by corrosive media. This "chromium improverishment theory" was claimed to be substantiated by Chevenard et al. (3) Payson ${ }^{(4)}$ proposed that the size and distribution of the precipitate were probably the most important factors in the phenomenon of intergranular corrosion. He suggested that the grain boundary attack merely depends on the presence of a continuous fine precipitate without special reference to the nature of the precipitated carbides.

A successful theory should not only explain the chemical and metallurgical changes but also predict the failure mode e.g. whether the failures are intergranular, transgranular, or a complex mixed mode during intergranular corrosion. However, due to the fact that in reality the fracture mode varies with material and environmental factors, the mechanism by which sensitization affects intergranular corrosion or IGA resistance is still not certain at the present time.

\subsection{Time-Temperature-Sensitization Diagrams}

The degree of sensitiation is often represented by plotting the sensitization temperature and annealing time as a function of some measured sensitization factor. The corrosion rate of the sensitized alloys, 
after exposing to a standard corrosive solution for a given time, has been commonly used in the past. Other techniques involving the metallographic measurement of grain boundary penetration or the determination of residual stresses after exposure to a standard corrosive solution. There are several standard corrosion solutions used to evaluate alloy sensitization, (2) and they are briefly described as follows:

\section{(1) Copper-Copper Sulfate-Sulfuric Acid Test \\ (ASTM A-262, Practice E)}

The first widely used test for detecting susceptibility to intergranular corrosion was an early version of the boiling acidified copper sulfate test commonly known as the Strauss Test and described in ASTM A-393. The assessment of damage is usually made by bending the exposed specimen through $180^{\circ}$ and examining the outside surface for cracks after 72 hours exposure. With the high carbon steels, differentiation between solution annealed-water quenched material and sensitized material was quite satisfactory. However, Scharfstein and Eisenbrown ${ }^{(5)}$ have shown that a Type 304 heat containing $0.068 \%$ carbon would pass the 72 hour Strauss Test even after a sensitizing treatment of up to 4 hours at $677^{\circ} \mathrm{C}$.

The Copper-Copper Sulfate-Sulfuric Acid Test is an improved modification of the Strauss Test, employing the same solution composition but with test sample in contact with metallic copper. It is of comparable sensitivity to the other methods in $A-262$ and requires only 24 hours of boiling. Like the Strauss Test, interpretation is based on visual examination of bent test specimens so that the specimens are classified only as acceptable or nonacceptable. The ASTM has taken a position in 1973 to discontinue A-393 in favor of Practice $E$ of $A-262$. The improved copper-copper sulfate-sulfuric acid test is also being incorporated into the new international ISO/TC-17/SC-7 Standards for International Corrosion Tests for Austenitic Stainless Steels instead of the older acidified copper sulfate test described in A-393.

\section{(2) Nitric Acid Test \\ (ASTM A-262, Practice C)}

The boiling $65 \%$ nitric acid test, often referred to as the Huey Test, was first described by $W$. R. Huey in 1930. (6) Over the years, it has been 
the most widely used method in evaluating susceptibility to intergranular corrosion in America. Interpretation is based on corrosion rate calculated from weight loss, supplemented in some instances by visual or microscopic examination for grain dropping. A quantitative measure of the degree of sensitization is thereby provided for comparative purposes. However, the nitric test requires 240 hours boiling, and it also has certain other limitations which must be recognized and guarded against for proper interpretation of results.

Due to the presence of hexavalent chromium ions formed through the oxidation of $\mathrm{Cr}^{+3}$ to $\mathrm{Cr}^{+6}$ by the boiling $65 \%$ nitric acid, the test solution volume to specimen surface area ratio should be at least $125 \mathrm{ml} / \mathrm{in}^{2}$ to avoid accelerated corrosion. The hexavalent chromium ion effect in nitric acid testing can be avoided by the use of multisample testing equipment such as that originally described by Delong. (7)

The nitric acid test was successfully used for many years to detect harmful carbide precipitation in normal grades of stainless steels. However, for the low carbon $(0.03 \%$ max.) grades alloys such as Types $304 \mathrm{~L}$, $316 \mathrm{~L}$, and $317 \mathrm{~L}$ stainless steels, the nitric test is also sensitive to some other phase or heat treatment, which experience shown does not cause intergranular attack in other environments. This phase has been generally assumed to be submicroscopic sigma. ${ }^{(2)}$ Since the other methods described in A-262 are not sensitive to the presence of submicroscopic sigma in the low carbon grades of stainless steels, the nitric test should not be used for evaluation of these grades unless the material represented is actually intended for nitric acid service.

\section{(3) Ferric Sulfate-Sulfuric Acid Test (ASTM A-262, Practice B)}

The ferritic sulfate-sulfuric acid test, of ten referred to as the Streicher test or the ferric sulfate test, was originally described by M. A. Streicher in $1958 .^{(8)}$ It is of comparable sensitivity to the nitric test but requires only half the boiling time, while retaining the advantage of a numerical corrosion rate for comparison of the relative performance of the specimens evaluated. It is not sensitive to the presence of submicroscopic sigma phase in Type $316 \mathrm{~L}$ and Type $317 \mathrm{~L}$ as produced by the 
usual sensitizing treatment ( 1 hour at $677^{\circ} \mathrm{C}$ ), and in Du Pont practice, the ferric sulfate test has long been used for the evaluation of these grades. However, there are a few precautions referred to in A-262 which can be rigidly observed.

\section{(4) Nitric-Hydrofluoric Acid Test (ASTM A-262, Practice D)}

The nitric-hydrofluoric acid test as adopted for evaluation purposes was first described by $D$. Warren in 1958. (9) It consists of two 2-hour periods in $10 \% \mathrm{HNO}_{3}-3 \%$ HF solution at $70^{\circ} \mathrm{C}\left(158^{\circ} \mathrm{F}\right)$ and thus requires 1 ess testing time than any of the other methods. This method was developed specifically to differentiate between precipitated carbides and submicroscopic sigma in the molybdenum bearing grades. As described in A-262, it applies only to the evaluation of Type $316,316 \mathrm{~L}, 317$, and $317 \mathrm{~L}$ stainless stee 1s.

(5) Oxalic Acid Etch Test

(ASTM A-262, Practice A)

The oxalic acid etch test is not actually an evaluation test but a formalized classification of etch structures which is used to screen out those specimens which would unquestionably pass the applicable evaluation test as 1isted in A-262. It was first described by Streicher in $1953(10)$ and the results of an ASTM Cooperative Testing Program were published in 1954. (11) Details of procedure and classification are given in A-262.

The typical time-temperature sensitization curves for several alloys exposed in the standard Huey solution are given in Figures 3.1-1 and 3.1-2. The degree of sensitization is measured in terms of corrosion rate. The precipitation of carbides, mainly $(\mathrm{Cr}, \mathrm{Fe}){ }_{23} \mathrm{C}_{6}$ type, along grain boundaries and twin boundaries causes the alloys to become sensitized and extremely susceptible to grain boundary attacks. The time-temperature-susceptibility to intergranular attack relationship for the unstabilized 300 series austenitic stainless steels is given in Figure 3.1-3. (12) The nature of these curves along with the influences of alloying additions are discussed in the following section. 


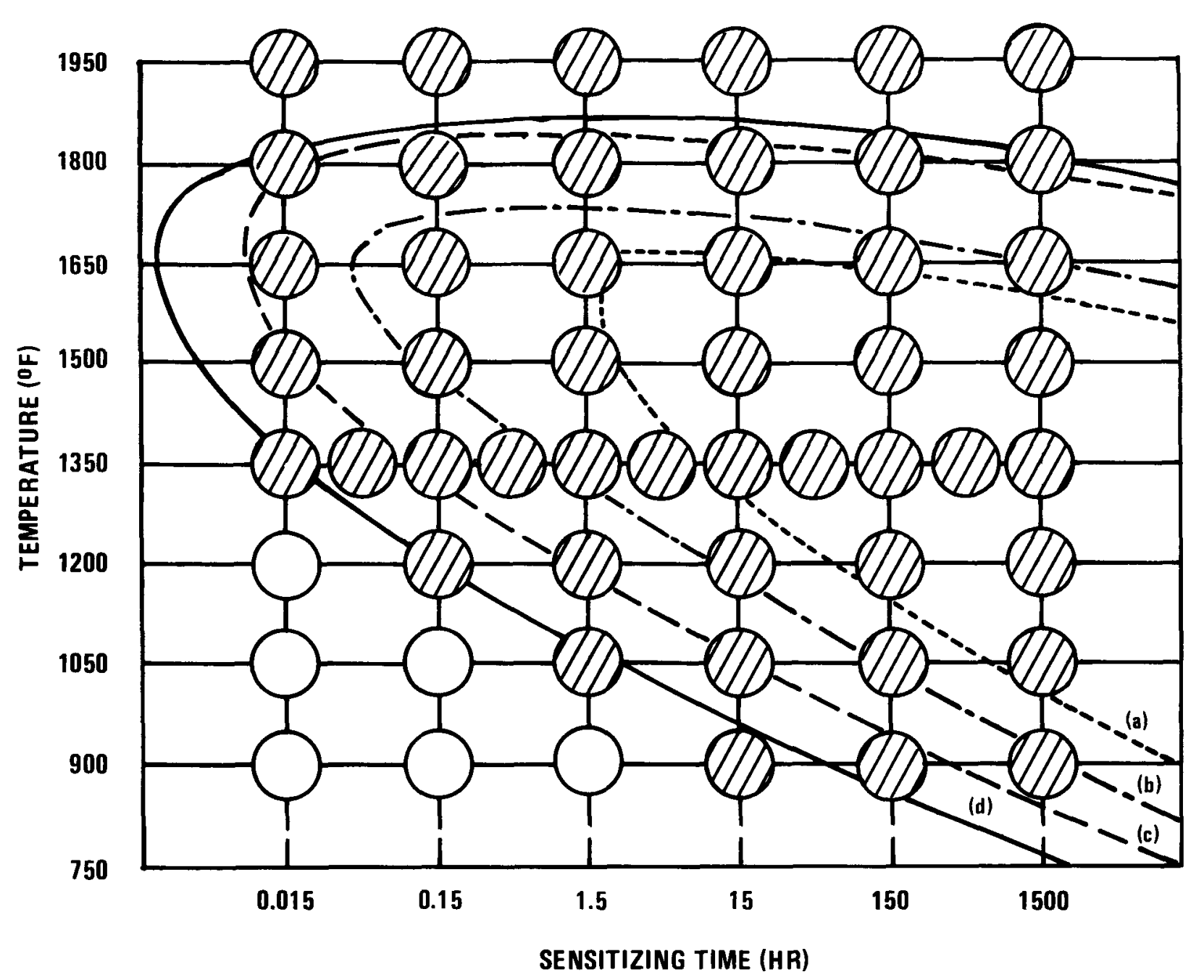
(a) COHERENT TWIN BOUND ARIES
(b) INCOHERENT TWIN BOUNDARIES
(c) INSIDE AUSTENITE GRAINS
(d) AUSTENITE-FERRITE GRAIN BOUNDARIES

Figure 3.1-1. Time-Temperature Dependence of Carbide Precipitation in Type 304 Stainless Steel (Reference 11 ). 


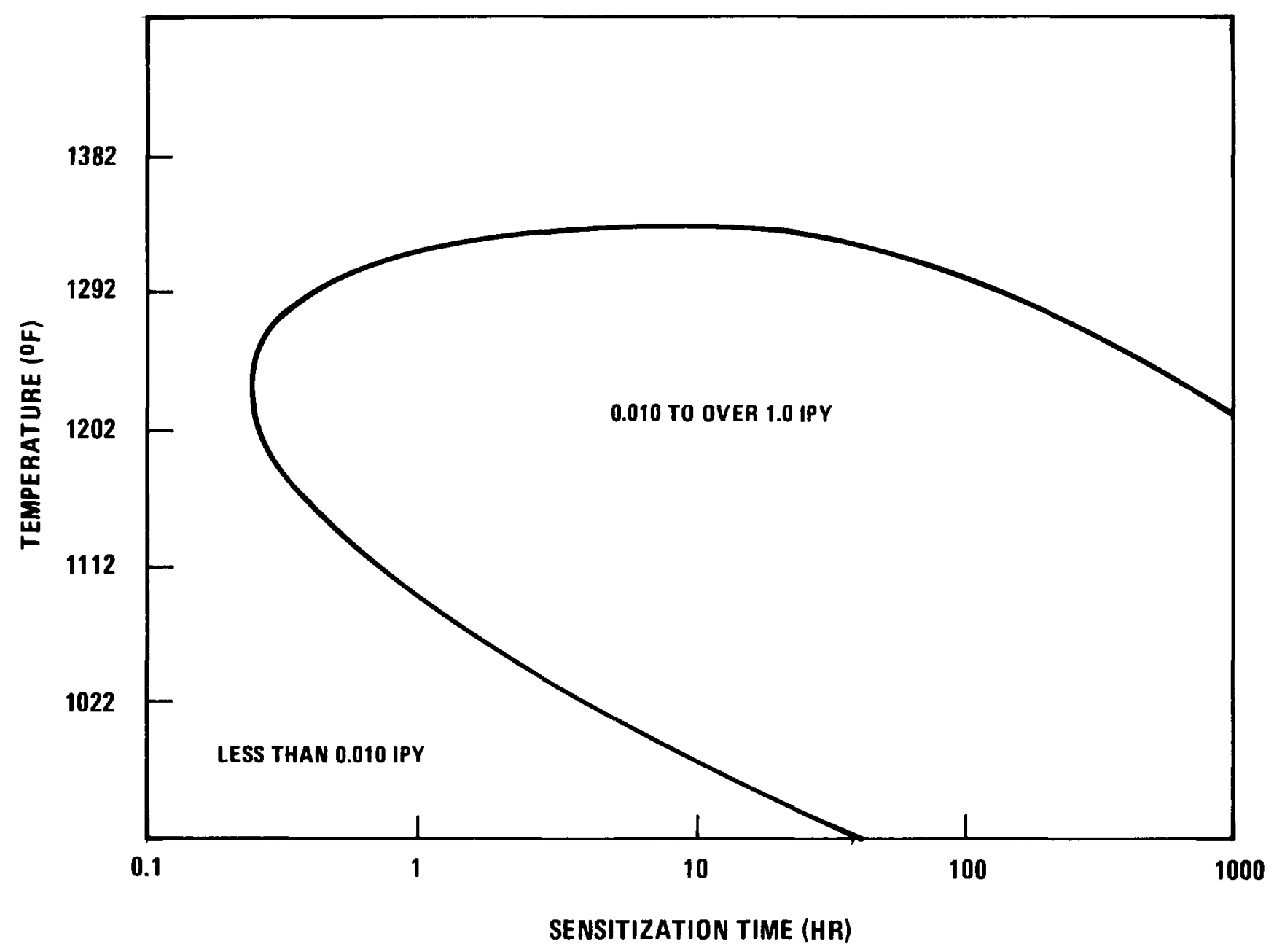

Figure 3.1-2. Time-Temperature-Sensitization Diagram of Type 304 (0.054\% C) Stainless Steel (Huey Test) (Reference 11.) 


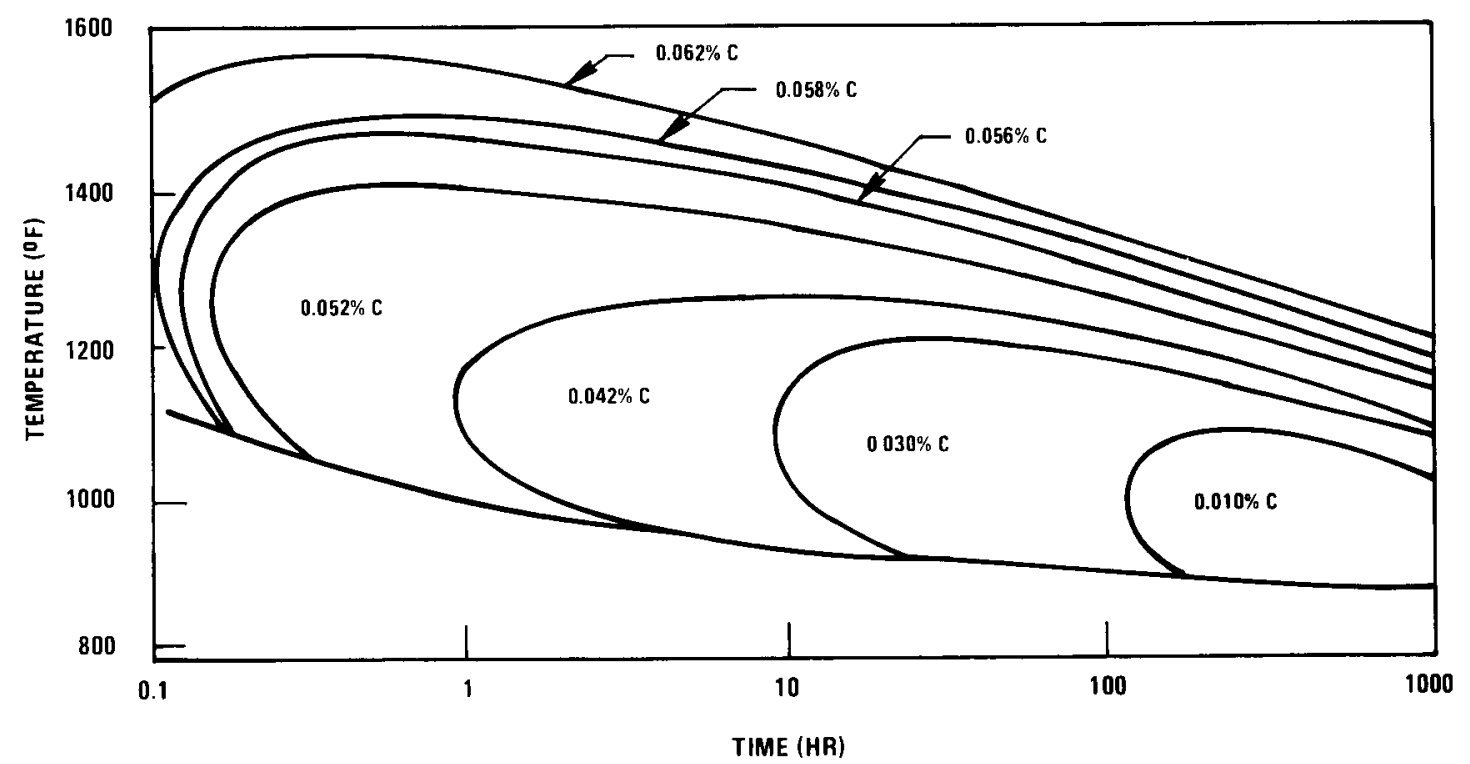

Figure 3.1-3. Onset of Susceptibility to Intergranular Attack in 18-8 Stainlew Steel as a Function of Carbon Level (Reterence 12 )

\subsection{Effects of Alloy Chemistry}

The normal grades of austenitic stainless steels, such as Types 301 , $302,304,308,309,316$, and 317 , are normal1y used in the solution annealed condition in which the carbides and nitrides are re-dissolved in the alloy matrix. Alloys in this condition have maximum corrosion resistance. Since they are free of intergranular carbides, they should not be susceptible to intergranular corrosion. However, if this class of stainless steel is held in a temperature range of from 800 to $1500^{\circ} \mathrm{F}$ (427 to $815^{\circ} \mathrm{C}$ ), carbide precipitation will occur particularly along grain boundaries. Consequently, the alloys are sensitized and thus susceptible to intergranular attack. 
There are many ways to reduce or eliminate sensitization problems. However, from chemistry point of view there are two ways in which the composition of the austenitic stainiess steels may be modified to reduce the susceptibility to sensitization. The most direct and simple way is to reduce the carbon content in these alloys thus reducing intergranular carbide precipitation. To differentiate from the normal grades of stainless steels, the low carbon austenitic stainless steels are identified as the "L" grade of stainless stee1. In Figures 3.2-1 and 3.2-2, (1) it is noted that the time to reach a given degree of sensitization, at a given temperature, may be increased by approximately an order of magnitude with respect to the normal grade alloys shown in Figures 3.1-1 and 3.1-2. It should be recognized however, that reducing the carbon content of the alloys will only reduce and delay the intergranular carbide precipitation and will not eliminate the sensitization problem.

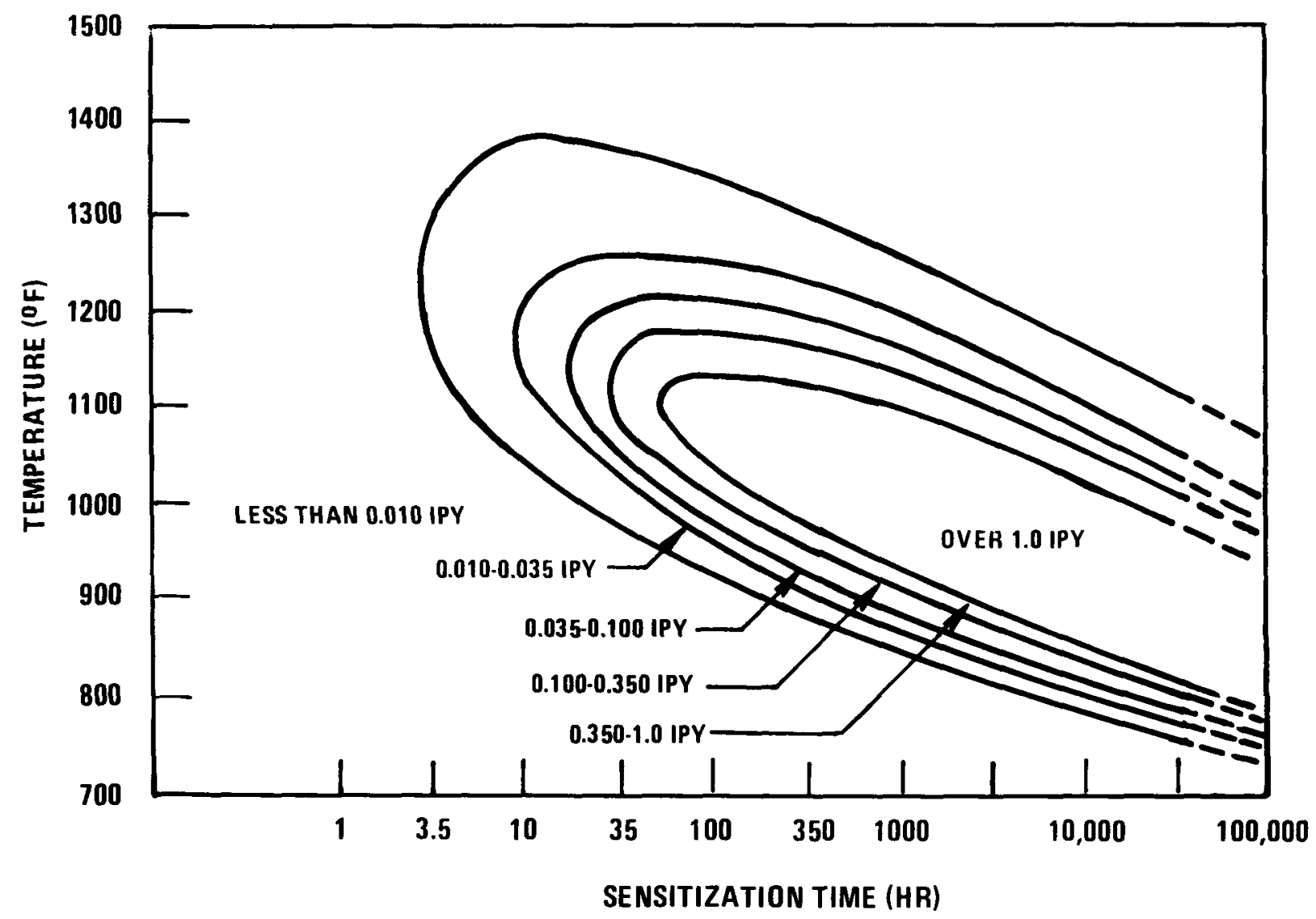

Figure 3.2-1. Time-Temperature-Sensitization Diagram of Type 304L Stainless Steel (Huey Test) (Reference 1 ). 


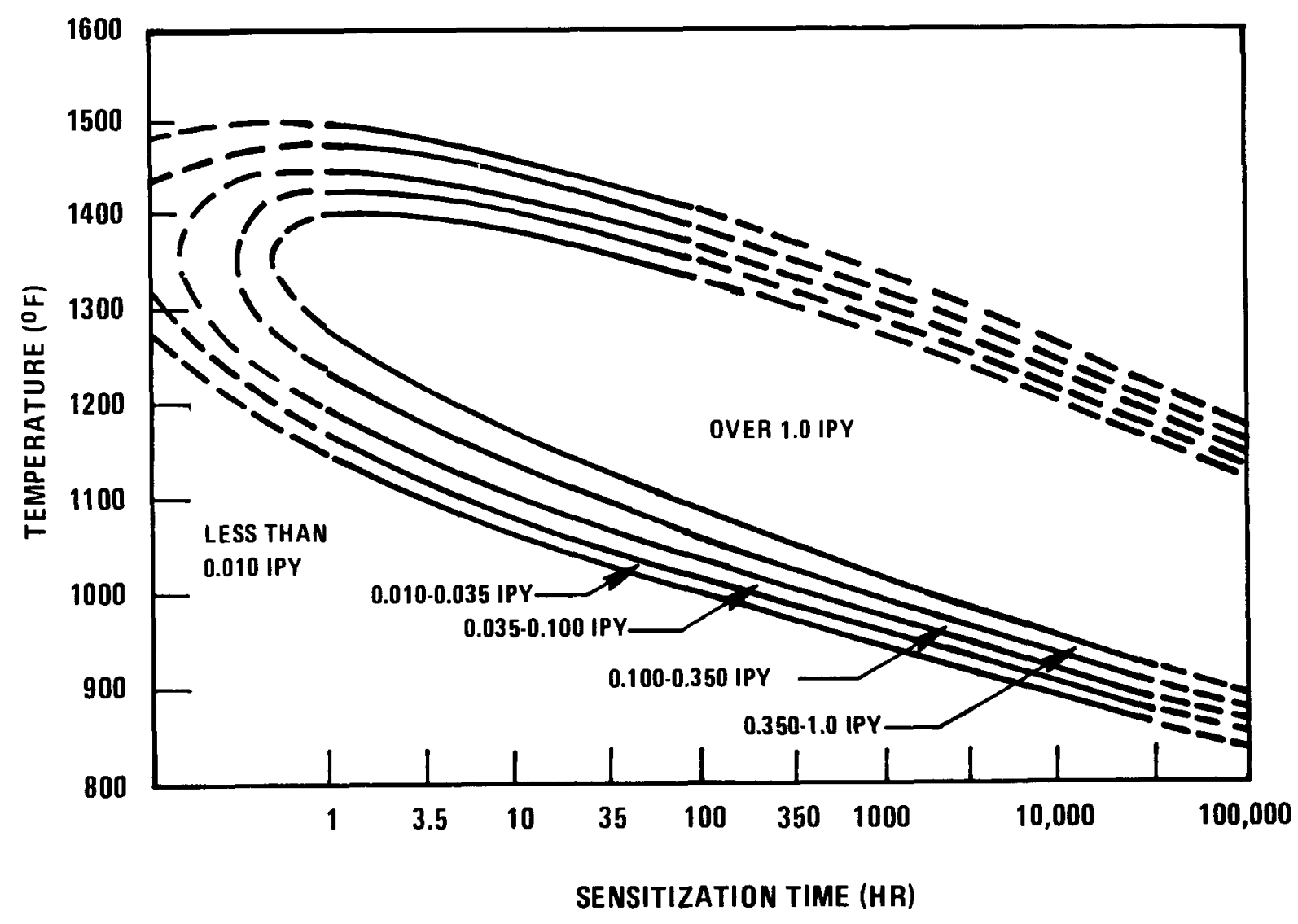

Figure 3.2-2. Time-Temperature-Sensitization Diagram of Type 316L Stainless Steel (Huey Test) (Reference 1).

The second method in reducing sensitization effects involves modifying the alloy composition by adding elements which form more stable carbides than chromium $(\mathrm{Cr})$. Consequently, the modified alloys are designated as the "stabilized" grade austenitic stainless steels and include Type 321 SS in which titanium ( $T i$ ) is added, and Types 347 and 348 containing both niobium (Nb) and tantalum ( $\mathrm{Ta}$ ). Since $\mathrm{Ti}, \mathrm{Nb}$, and $\mathrm{Ta}$ have higher affinity for carbon than $\mathrm{Cr}$ and they also form the MC type monocarbides, they form carbides throughout the grains in contrast to $\mathrm{M}_{23} \mathrm{C}_{6}$ type carbides which formed preferentially along the grain boundaries where diffusion of $\mathrm{Cr}$ is more readily. Therefore, susceptibility to intergranular attack is significantly reduced for the stabilized austenitic stainless steels. In 
Figure 3.2-3 the time-temperature-sensitization diagram of Type 347 SS is shown. It is noted that the stabilizing additions are more effective in delaying sensitization than the simple method of reducing the carbon content.

\subsection{Effect of Cold Work}

Cold working is generally believed to enhance the resistance of austenitic stainless steels to IGA. Weiss and Stickler ${ }^{(13)}$ reported that cold work of solution treated Type 316 stainless steel for less than 20 pct. results in the formation of stacking fault clusters, at deformation exceeding 20 pct. increasing numbers of bands of deformation microtwins were observed. Aging heat treatments of the cold-wroked steels resulted in accelerated precipitation of carbides and intermetallic compounds within the grains, thus, reduce the amount of grain-boundary carbide precipitation. In the study of corrosion behavior of sodium-exposed stainless steels in chloride-containing aqueous solutions, $\mathrm{Wu}^{(14)}$ also reported that cold working had enhanced the resistance of Type 316 stainless steel to IGA.

\subsection{Failure of Sensitized Nuclear Components}

Failures of sensitized austenitic stainless steel components in watercooled reactors were reported by Cheng. (15) In general, failure occurred during the period immediately prior to, or during, early reactor operation. Intergranular attack (IGA) in the containment tanks and shield plug/support cylinder (SP/SC) assemblies of the Fast Flux Test Facility (FFTF) primary pumps was also reported by Cwynar et a1. (16) The sensitization-induced cracking were confined to Type 304 stainless steel plate and forging material which had been subjected to a long-term anneal at $1150^{\circ} \mathrm{F}$ to assure the in-service dimensional stability of critical pump components. The exact cause of the reported IGA of FFTF primary pump componnets was not established. However, it is strongly indicated that the problem arose because of the fluoride-rich welding flux debris present on sensitized Type 304 stainless steel surfaces as a result of cleanup grinding. Interactions of this residue with a moist air environment subject to wide diurnal temperature changes, and very high residual stresses in the material would be sufficient to produce the observed cracks. 


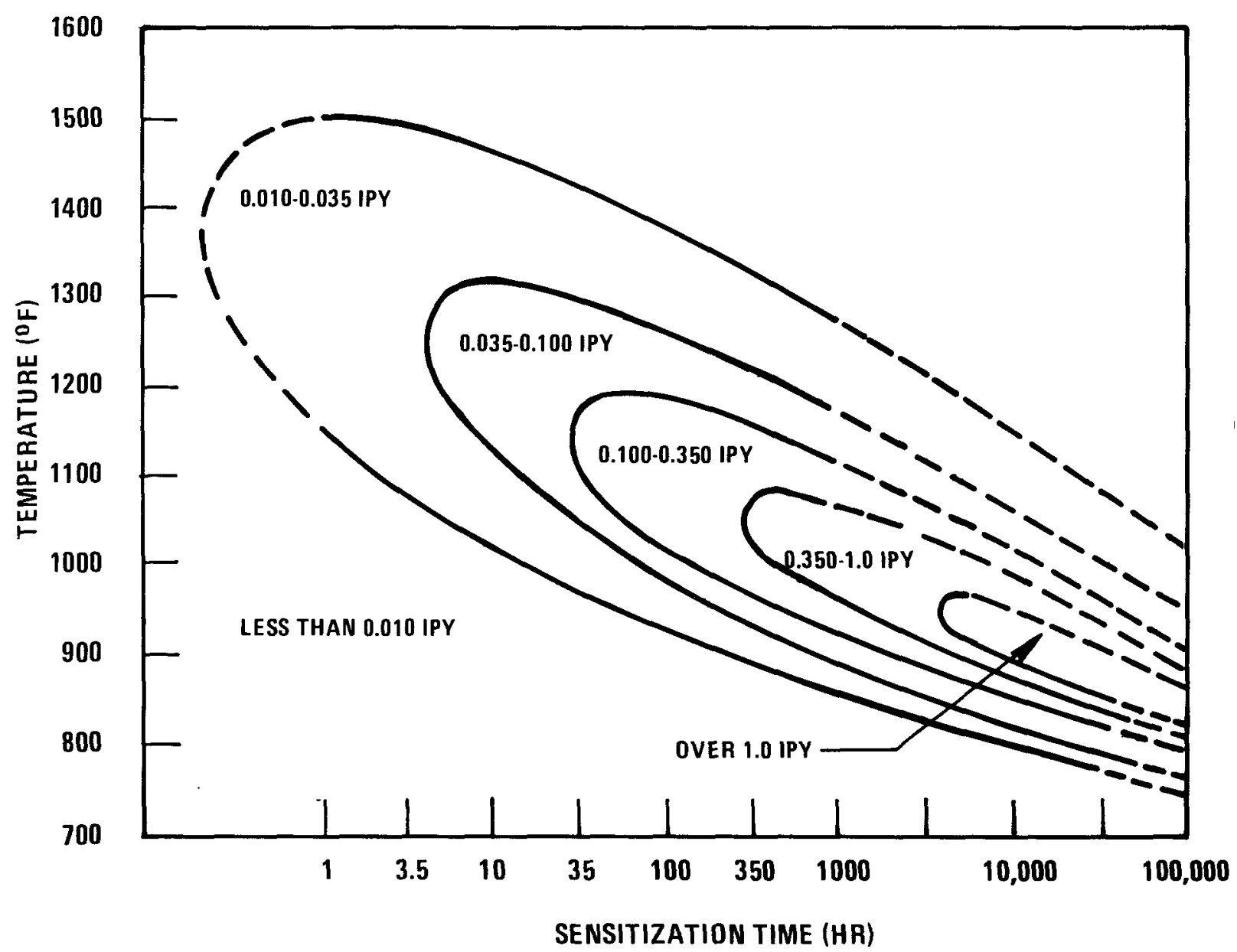

Figure 3.2-3. Time-Temperature-Sensitization Diagram of Type 347 Stainless Steel (Huey Test) (Reference 1).

\subsection{How To Avoid Intergranular Attack}

Since intergranular attack (IGA) occurs mainly to the sensitized austenitic stainless steels, the most obvious way to avoid IGA would be not to permit any fabrication or annealing operations which involve exposure of unstabilized grades of stainless steel to the temperature range of from 800 to $1600^{\circ} \mathrm{F}$. Unfortunate $1 \mathrm{y}$, when stability is required, stress relieving heat treatments of stainless steel components are generally carried out in this temperature range. In addition, certain fabrication operations such as welding cannot be performed without subjecting some areas of the component to the above temperature range. Consequently, total el imination of sensitized microstructure would be impossible without solution annealing after fabrication. 
However, techniques are available (see References 1 and 12) in practice to reduce and control this problem. If stress relieving heat treatments in the sensitization range are necessary, the use of a "L" grade stainless steel such as type 304L SS or Type 316L SS (if feasible from strength standpoint) or a stabilized grade of stainless steel such as Type 321 or Type 347 SS, will delay the onset of grain-boundary carbides precipitation and thus reduce the problem of sensitization.

In the case of welds, it is pussible to minimize the heat affected zone (HAZ) by limiting the arc heat input and through the use of a maximum interpass temperature such as $350^{\circ} \mathrm{F}\left(177^{\circ} \mathrm{C}\right)$ as suggested in Reference 12 . Due to the short time duration in the range of from 800 to $1500^{\circ} \mathrm{F}$ (427 to $816^{\circ} \mathrm{C}$ ) weld heat-affected zones are not sensitized to the degree that material given an isothermal anneal in the same temperature range would be. Caution must be exercised, however, in assuming that weld HAZ are not sensitized, since "weld decay" i.e., corrosion at welds, is observed under severe corrosive conditions even when precautions are taken to minimize heat input during welding.

Other approaches to avoid intergranular attack generally involve rigid control of contamination of components during the fabrication, shipping, and pre-service period of the reactor. Contamination which has occurred should immediately be removed according to accepted procedures for the given material and contaminant. It was also reported ${ }^{(12)}$ that the most effective control measure in avoiding IGA is the maintenance of the sensitized part or component in a dry environment. The atmosphere surrounding the sensitized material should not exceed a relative humidity of $40 \%$. When fluids must be utilized for nondestructive examination or fabrication, they should remain in contact with the sensitized material for the shortest time possible and then be removed so as to restore the surface to a clean dry condition. Those fruids which are allowed to come into contact with the surface should be as low in halides as is feasible. It is impossible to specify all corrosive contaminants and their concentrations which can result in intergranular attack. In Table 3.4-1 a partial listing of corrosives which have been reported to induce attack is given. 
TABLE 3.4-1

CORROSIVES REPORTED TO INDUCE INTERGRANULAR CORROSION IN SENSITIZED AUSTENITIC STAINLESS STEEL

Acetic acid

Acetic acid + salicylic acid

Ammonium nitrate

Ammonium sulfate

Anmonium sulfate $+\mathrm{H}_{2} \mathrm{SO}_{4}$

Beet juice

Calcium nitrate

Chromic acid

Chromium chloride

Copper sulfate

Crude oil

Fatty acids

Ferric chloride

Ferric sulfate

Formic acid

Hydrocyanic acid

Hydrocyanic acid + sulfur dioxide

Hydrofluoric acid + ferric sulfate

Lactic acid

Lactic acid + nitric acid

Maleic acid

Nitric acid

Nitric acid + hydrochloric acid

Nitric acid + hydrofluoric acid
Oxalic acid

Phenol + napl thenic acid

Phosphoric acid

Phthalic acid

Salt spray

Sea water

Silver nitrate + acetic acid

Sodium bisulfate

Sodium hydroxide + sodium sulfide

Sodium hypochlorite

Sulfite cooling liquor

Sulfite solution

Sulfite digester acid

(calcium bisulfite + sulfur dioxide)

Sulfamic acid

Sulfur dioxide (wet)

Sulfuric acid

Sulfuric acid + acetic acid

Sulfuric acid + copper sulfate

Sulfuric acid + ferrous sulfate

Sulfuric acid + methanol

Sulfuric acid + nitric acid

Sulfurous acid

Water + starch + sulfur dioxide

Water + aluminum sulfate

Water + fluoride containments (such

as weld flux or smoke) 


\subsection{STRESS CORROSION CRACKING}

The general significance and ramifications of the problem of stress corrosion cracking of austenitic chromium-nickel steels and its industrial limitations were discussed by Hodge and Miller. (17) Previously, most of the cracking problems in stainless steels were attributed to fatigue or weld cracking. As stated by Staehle ${ }^{(18)}$ it was inconceivable, for example, that a few ppm of chloride would be sufficient to produce such debilitating consequences as observed.

In recent years, due to the development of nuclear industry as well as the advancement in aerospace technology, recognition of the problem of stress corrosion cracking has become widespread not only with respect to environments which cause cracking but also with respect to alloy systems which crack. Even the often stated general truth that pure metals do not crack is in doubt. (18) For some time the titanium alloys were thought to be immune to stress corrosion cracking, however, they are now found to be susceptible to intergranular and transgranular cracking in such diverse environments as liquid nitrogen tetroxide $\left(\mathrm{N}_{2} \mathrm{O}_{4}\right)$, methanol, and salt water. Similarly, Inconel 600 , an often used alternative for stainless steels in chloride environments, has been shown to be susceptible to both modes of cracking in such unpretentious environments as high purity water in the $300^{\circ} \mathrm{C}$ range with a few ppm of oxygen or lead contamination. (18)

Sensitization in austenitic iron-nickel-chromium alloys is associated with the precipitation of carbides in the grain boundaries. Interest in this phenomenon stems from reported significance in the intergranular corrosion cracking for some stainless steel/environment combinations. (1) The prerequisite for stress corrosion cracking are a combination of the presence of either an applied or residual stress, exposure to some minimum temperature, the presence of a corrosive agent with a concentration above certain minimum level and most frequently in aqueous solutions, and an adequate incubation time. The basic differences between intergranular attack and stress corrosion cracking is that the latter requires the presence of a threshold stress, while sensitization of the material is not a prerequisite for cracking to take place. 


\subsection{Stress Corrosion Cracking of Fe-Cr-Ni Alloys}

Although stress corrosion cracking is a problem encountered in the application of ferrous as well as nonferrous alloys, the main emphasis of the present review has been 1 imited to the $\mathrm{Fe}-\mathrm{Cr}-\mathrm{Ni}$ alloys such as the austenitic stainless steels, Inconels, and some ferritic stainless steels. The austenitic stainless steels are the major materials of construction in most water cooled thermal reactors as well as the LMFBRs. In the water cooled nuclear reactors, these alloys are used extensively in contact with the primary coolant as piping, valves, pumps, and heat exchangers. Previousiy, the niobium stabilized (Type 347) stainless steels were used in the early water cooled nuclear reactors because of their known resistance to intergranular attack by strong chemicals that might be encountered during fabrication. Due to economic as well as practical (welding) considerations, Type 304 and 316 stainless steels were used in later commercial nuclear electricity generating plants.

Both Type 304 and Type 316 stainless steels become sensitized when thermally treated in the temperature range of about 800 to $1500^{\circ} \mathrm{F}$ (427 to $815^{\circ} \mathrm{C}$ ) and, thus, this practice is, in general, avoided. However, certain fabrication processes such as attaching various components to the pressure vessel requires that the vessels be heated to 1150 to $1200^{\circ} \mathrm{F}\left(620\right.$ to $\left.650^{\circ} \mathrm{F}\right)$ to stress relieve the carbon steel members of these components and, thus, sensitize the structure. Welding also produces a band of sensitization in the wrought metal adjacent to the weld (heat affected zones). Therefore, large components and piping which are not solution treated after welding, contain sensitized heat affected zones.

Early in the development of nuclear reactors, cursory studies showed that sensitized stainless steel performed well in high temperature water. However, in 1967, stress corrosion cracking (SCC) was reported adjacent to a weld in small diameter piping in a boiling water reactor that had been in operation for some 5 to 7 years. (19) More recently, stress corrosion cracking has occurred in stainless steel components that had been heavily sensitized during the carbon steel stress relieving treatments and had been subjected to high oxygen content water during reactor 
operation. (19) The common features of these failures appeared to be intergranular stress corrosion cracking in a sensitized microstructure of material that had been highly stressed (plastically strained) and exposed to high temperature water containing $\geq 0.2 \mathrm{ppm}$ dissolved oxygen.

In genera1, most LMFBR components will not be susceptible to stress corrosion cracking during operation, however, care must be taken to avoid chloride contamination during other stages of plant life and from the outer surfaces during operation. The use of liquid sodium as a heat transfer medium raises the possibility of the formation of sodium hydroxide and the resultant danger of caustic stress corrosion cracking of components. In addition, the problems of caustic stress corrosion cracking have to be addressed adequately in the development of LMFBR fuel reprocessing technology in order to assure the capability of completing the fuel cycle in a sodium cooled fast breeder reactor economy.

\subsection{Cracking of Fe-Cr-Ni Alloys in Chloride Environments}

The stress corrosion cracking (SCC) of austenitic stainless steels in aqueous chloride environments is a well documented but inadequately understood phenomena. Characteristic features of this SCC process are that cracking follows mainly transgranular paths, and it is induced by chloride pitting of the passivated alloys. The cracking occurs in conjunction with electrochemical corrosion reactions. The minimum chloride concentration for SCC differs among the various alloy systems because of the effects of other ions, $\mathrm{pH}$, surface condition and such processes as alternate wetting and drying.

The environmental and metallurgical factors influencing alloy susceptibility to chloride SCC have been reviewed by many authors, $(1,20-22)$ and the detailed mechanistic postulates were also presented to account for the occurrence of chloride induced stress corrosion cracking. The data shown in Table 4.2-1 are an example of the varied nature of the cracking attributed to chloride ion stress corrosion cracking. The table shows that cracking of austenitic stainless steel components can occur at a chloride concentration as low as 4-5 ppm, and the temperature can be as low as $70^{\circ} \mathrm{F}\left(22^{\circ} \mathrm{C}\right)$. The organic chlorides and the chlorides in insulation and 
from soldering fluxes can also induce failure. Additional cases of chloride induced SCC of austenitic stainless steel components during service were discussed by Warren, ${ }^{(23)}$ Staehle, ${ }^{(24)}$ and Cheng. (15)

\subsubsection{Pitting of Fe-Cr-Ni Alloys in Chloride Environment}

In the process of localized corrosion of stainless steel, typically pitting in chloride solutions, the nature of the anolyte within local anodes changes remarkably through rapid dissolution in the restricted area where mass transport is difficult. The change in neutral chloride solutions results in an increase of the chloride ion concentration and a decrease of the $\mathrm{pH}$, followed by the acceleration of the anodic dissolution. The dissolution process within a pit, therefore, has an autocatalytic nature. From electrochemistry standpoint, the rate of corrosion pitting is determined, ultimately, by the action of a concentration cell, the corrosion is generated by nonuniform aeration, i.e., by a deficiency of oxygen in the pit and a consequent damage to the passive state of the stainless steels.

In investigating localized corrosion such as pitting, it is important to have detailed knowledge of the solution and $i$ ts change within the local anode area. However, quantitative studies taking into account of a11 the anions and cations involved have not been carried out except those concerning only the $\mathrm{pH}$ or a few other ions. Suzuki et al., ${ }^{(25)}$ based on their chemical and electrochemical studies on the solution within artificial pit anodes of some stainless steels, concluded that a high anodic current density increases the concentration of metal ions in the anolyte, and their hydrolysis increases the concentration of $\mathrm{H}^{+}$to lower the $\mathrm{pH}$ of anolyte. In addition, the lower $\mathrm{pH}$ increases the solubility of oxide or hydroxide formed on the metal surface to increase the anodic current density.

In their study of the influence of hydrogen on pitting corrosion and stress corrosion of austenitic stainless steel in chloride environment, Seys et al., (26) concluded from their study on the mechanism of pitting corrosion that during the pitting corrosion process of austenitic stainless steel in chloride environment, hydrogen development occurs inside the pit, even under anodic polarization conditions in a basic environment. The hydrogen diffuses in the austenitic steel around the pit and causes: 
TABLE 4.2-1

INDUSTRIAL $\mathrm{Cl}^{-}$ION STRESS CORROSION FAILURES (?)

\begin{tabular}{|c|c|c|c|c|c|c|c|c|}
\hline Equipsent & $\begin{array}{l}\text { Boiler feedwater } \\
\text { deaerating. heater }\end{array}$ & Fan & $\begin{array}{l}\text { Textile } \\
\text { Machine }\end{array}$ & Condensor & Water Tank & Kettle & $\begin{array}{l}\text { Expansion } \\
\text { bellows }\end{array}$ & $\begin{array}{l}\text { Adsorption } \\
\text { unit }\end{array}$ \\
\hline The to cracking & & - & 15 months & 2.5 yrs & & 6 months & 7 months & $600 \mathrm{hrs}$ \\
\hline Material & 304 S.S. & 304 s.s. & 304 s.s. & 304 s.s. & 304 s.s. & 304 s.s. & 316 s.s. & $\begin{array}{l}304,316, \\
317,347\end{array}$ \\
\hline $\begin{array}{l}\text { Service } \\
\text { Environtent }\end{array}$ & Steam/water & LiC1 fumas & $\begin{array}{l}\text { Dyes containing } \\
\text { aniline } \\
\text { hydrochloride }\end{array}$ & Water & Atm \& insulation & Soup & Flue gas & $\begin{array}{l}\text { Methylene } \\
\text { Chioride }\end{array}$ \\
\hline Cnlorides & 4-5 ppm avg. & - & $0.025 \%$ & $6 \mathrm{ppm} \mathrm{AaCl}$ & $\mathrm{Cl}^{-}$in insulation & $\begin{array}{l}\mathrm{Cl}^{-} \text {from } \\
\text { soldering fluxes }\end{array}$ & $\mathrm{CI}^{-}$in gas & $\begin{array}{l}\text { Wethylene } \\
\text { Chloride }\end{array}$ \\
\hline $\mathrm{pH}^{\mathrm{H}}$ & - & - & 7.0 & 4.5 & - & - & - & $.005 \% \mathrm{HCl}$ \\
\hline Temp. & - & $70^{\circ} \mathrm{F}$ & $212^{\circ} \mathrm{F}$ & $75-170^{\circ} \mathrm{F}$ & - & - & $250-300^{\circ} \mathrm{F}$ & $103+238^{\circ} \mathrm{F}$ \\
\hline seracton & - & - & Exposed to atr & D1ssclvad $\mathrm{O}_{2}$ & - & - & - & Acrufed \\
\hline $\begin{array}{c}\text { Source of } \\
\text { Stress }\end{array}$ & $\begin{array}{c}\text { From bend1ng } \\
\text { \& welding }\end{array}$ & $\begin{array}{c}\text { Cold } \\
\text { stamping }\end{array}$ & Welding & Thermal & Forming & $\begin{array}{l}\text { Vibration } \\
\& \text { welds }\end{array}$ & $\begin{array}{l}\text { Fabrication } \\
\text { \& service }\end{array}$ & $\begin{array}{c}\text { Fabrication } \\
\text { s service }\end{array}$ \\
\hline
\end{tabular}


(1) an increased anodic reactivity, (2) transformations of the austenite into martensite and ferrite, (3) an embrittlement of the meta? around the pit, and (4) a buildup of internal stresses in the metal. They reported that hydrogen can pin mobile dislocations which apparently initiate the secondary pits. The growing gas bubbles at the bottom of the pit cause an additional potential drop. Although the hydrogen development inside the pit is not of primary importance in the pitting corrosion process, it has significant importance in the mechanism of stress corrosion cracking. Finally, the factors which control the pitting corrosion are the concentrations of $\mathrm{H}^{+}$and $\mathrm{Cl}^{-}$ions in the pit electrolyte.

\subsubsection{Stress Corrosion Cracking Mechanisms for Fe-Cr-Ni Alloys}

The term stress corrosion cracking usually relates to failure which requires conjointly a tensional stress and a specific environment. Consequently, any workable failure mechanism must include these two factors. The large number of variables and specific conditions entering the phenomena of stress corrosion cracking support the conclusion that the mechanism of SCC is very complicated and not easily derived. The chemistry, metallurgy, and mechanics of metals and alloys undergoing fracture in a damaging environments are all essentials in deriving a successful theory to account for the phenomena of stress corrosion cracking.

There are several theories proposed to explain and account for SCC and an excellent review on the subject was given by Uhlig. (27) The present approaches can be categorized into the following mechanisms.

\subsubsection{The Electrochemical Theory}

The electrochemical theory of stress corrosion cracking was first proposed by Dix. (28) He suggested that galvanic cells are set up between continuous intermetallic precipitates and the adjacent metal at grain boundaries or through paths within the grains, the ensuing corrosion acting under stress to open up a crack. The applied stress was considered helpful in rupturing surface films, thereby exposing fresh metal at the top of the crack, allowing the reaction to continue. Subsequent potential measurements on intergranular crack sensitive paths in various aluminum alloys substantiate the proposed mechanism. Furthermore, cathodic polarization prevented crack 
initiation, or the growth of cracks already started. The electrochemical theory, with certain modifications depending on the metal, was elaborated by Evans, (29) Parkins, (30) and many other investigators。(27)

Following Dix, it was observed that alloys such as the 300-series austenitic stainless steels, carbon steels, Ag-Au alloys or brass, are also susceptible to stress corrosion cracking even though intermetallic compounds are not predominant in these alloys and hence cannot be a supposed source of potential difference along crack-sensitive paths. Edeleanu(31) proposed that for austenitic stainless steels, ferrite produced by cold work ahead of the yielding crack might constitute the anodic path. But as was shown later, high nickel steels, e.g., $25 \% \mathrm{Cr}, 20 \% \mathrm{Ni}$, which do not undergo a phase transformation when plastically deformed, are subject to failure nevertheless. (27) Although cold work itself may sometimes markedly accelerate the corrosion rate of metals, e.g., of low carbon steels in $\mathrm{HCl}$ or $\mathrm{H}_{2} \mathrm{SO}_{4}$, stress corrosion cracking of such steels has not been reported in these media. Instead, cold work produces immunity of carbon steels in media causing stress corrosion cracking such as hot aqueous solutions containing $\mathrm{NO}_{3}^{-}$.

The weakness of electrochemical theory was revealed by observations that some metals crack only in specific electrolytes, whereas electrochemical action would in fact be expected in a variety of related chemical media of comparable electrical conductivity. Furthermore, there appears to be no reasonable electrochemical explanation why additions of extraneous anions to damaging environments should act as inhibitors for SCC, e.g., chlorides and acetates for carbon steels in boiling nitrate solutions. Consequently, simple galvanic effects between tip and walls of the crack are not alone sufficient to explain the cause of fracture.

\subsubsection{The Theory of Stress Sorption Cracking}

The mechanism of cracking by this name proceeds not by chemical or electrochemical dissolution of metal at the tip of a crack, but instead by weakening of already strained metal atom bonds through adsorption of the environment or its constituents. (27) The surface energy is said to be reduced, encouraging the metal to part under tensile stress. This mechanism is related to the simplified Griffith criterion of crack 
formation which equates strain energy in the metal to the surface energy of the incipient crack area. It is essentially the mechanism which Petch and Stables ${ }^{(31)}$ first suggested for hydrogen cracking of steels and which was later emphasized by Uhlig ${ }^{(32)}$ as being applicable to stress corrosion cracking of other metals and alloys.

Uhlig et al., (27) showed that only a monolayer of adsorbate (e.g. oxygen atoms) is necessary to decrease affinitive of surface atoms of themselves or for their environment, specifically adsorbed species chemically bonded (chemisorbed) to the surface being especially effective in this regard. Crack initiation is thought to involve a similar decrease in surface affinities with the distinction that only those specific adsorbates are effective which reduce the attractive forces for adjoining metal atoms located at the extreme root of a notch, subject to high tensile stress, and experiencing some plastic deformation. Certain adsorbed ions, and in some instances adsorbed water, do this more effectively for many metals and alloys than does oxygen. The latter adsorbs strongly but presumably retains, unlike adsorbed damaging species, a high affinity for adjacent adsorbed oxygen atoms, thereby preventing release of neighboring bonds necessary to crack initiation.

Uhlig (27) presented some additional arguments to support the view that stress sorption cracking is the prevailing mechanism in stress corrosion cracking of metals and alloys:

(1) Stress corrosion cracking occurs in a specific environment for a given alloy. Chemisorption is also specific.

(2) Anions in sufficient concentration tend by mass action to displace adsorbed damaging species. Or they may shift the corrosion potential into regions where the damaging species do not adsorb. For similar reasons, cathodic polarization is generally effective because the potential is shifted into regions where damaging species cannot adsorb. This explains the effect of inhibiting effect of extraneous anions and of cathodic protection in stress corrosion cracking. 
(3) The cracking of metals (embrittlement) by liquid metals especially parallels the characteristics of stress corrosion cracking in that onty specific solid metalliquid metal couples are damaging, and also a tensile stress is essential.

\subsubsection{Conclusion}

In summary, the main support of the electrochemical mechanism is contributed by potential measurements and the inhibiting effect of cathodic polarization. Unexplained is the required specificity of environments for cracking and the inhibiting effect of extraneous ions. In addition, the electrochemical mechanism can not explain the required above-room temperatures for cracking of austenitic stainless steels in chlorides and of carbon steels in alkalis; the transgranular cracking of sensitized 18-8 stainless steels in $\mathrm{MgCl}_{2}$ solution despite well developed corrosion sensitive path along grain boundaries; the sensitivity of molybdenumbearing 18-8 stainless steels (Type 316 SS) to stress corrosion cracking in chloride solutions despite their improved resistance over 18-8 (Type $304 \mathrm{SS}$ ) to pitting and to general corrosion attack by chlorides; and finally the susceptibility of $\mathrm{Ti}$ alloys to stress corrosion cracking in environments such as $\mathrm{CH}_{3} \mathrm{OH}$ or $\mathrm{CCl}_{4}$ which are not electrolytes.

The mechanism of stress sorption cracking plausibly accounts for many features of stress corrosion cracking. It also satisfactorily relates stress corrosion cracking in aqueous media to the mechanism of similar fracture in metals and non-metals from environmental causes not involving electrochemical reactions. However, this approach is a necessary-but-notsufficient type of argument in terms of the mechanism of stress corrosion cracking. Certainly, lowering the surface free energy of a crack surface by adsorption from the environment may make it thermodynamically possible for a crack to propogate, but thermodynamic possibility is not enough to insure that a reaction will in fact proceed, since kinetic barriers have to be overcome. 


\subsubsection{The Effect of Stress}

In addition to environment, the effect of alloying and the magnitude of tensile strength are all necessary considerations in defining stress corrosion cracking. In general, the effect of stress level in chloride solutions is for higher stresses to accelerate the rate of cracking. However, there has been disagreement on the existence of the so called "threshold stress" below which cracking will not occur. The determination of such a stress would be system dependent because factors such as material properties, temperature, $\mathrm{pH}$, etc. are all having significant effect. Denhard ${ }^{(33)}$ has conducted extensive tests on commercial stainless steels in $\mathrm{MgCl}_{2}$ solutions and has reported the composite curves shown in Figure 4.2-1 illustrating the relative stress corrosion cracking resistance for commercial stainless steels in boiling 42 percent magnesium chloride. The curves are similar to fatigue S-N curves but it would be incorrect to consider that there is a stress limit as in fatigue. Denhard points out that his results can be represented by two straight lines, similar to the work of Hoar and Hines ${ }^{(34)}$ which would have equations of the type:

$$
\log t_{f}=A+B \sigma
$$

where

$$
\begin{aligned}
t_{f} & =\text { time to failure } \\
A, B & =\text { constants } \\
\sigma & =\text { applied stress }
\end{aligned}
$$


$t_{f}=$ TIME TO FAILURE

$A, B=$ CONSTANTS

$\sigma=$ APPLIED STRESS

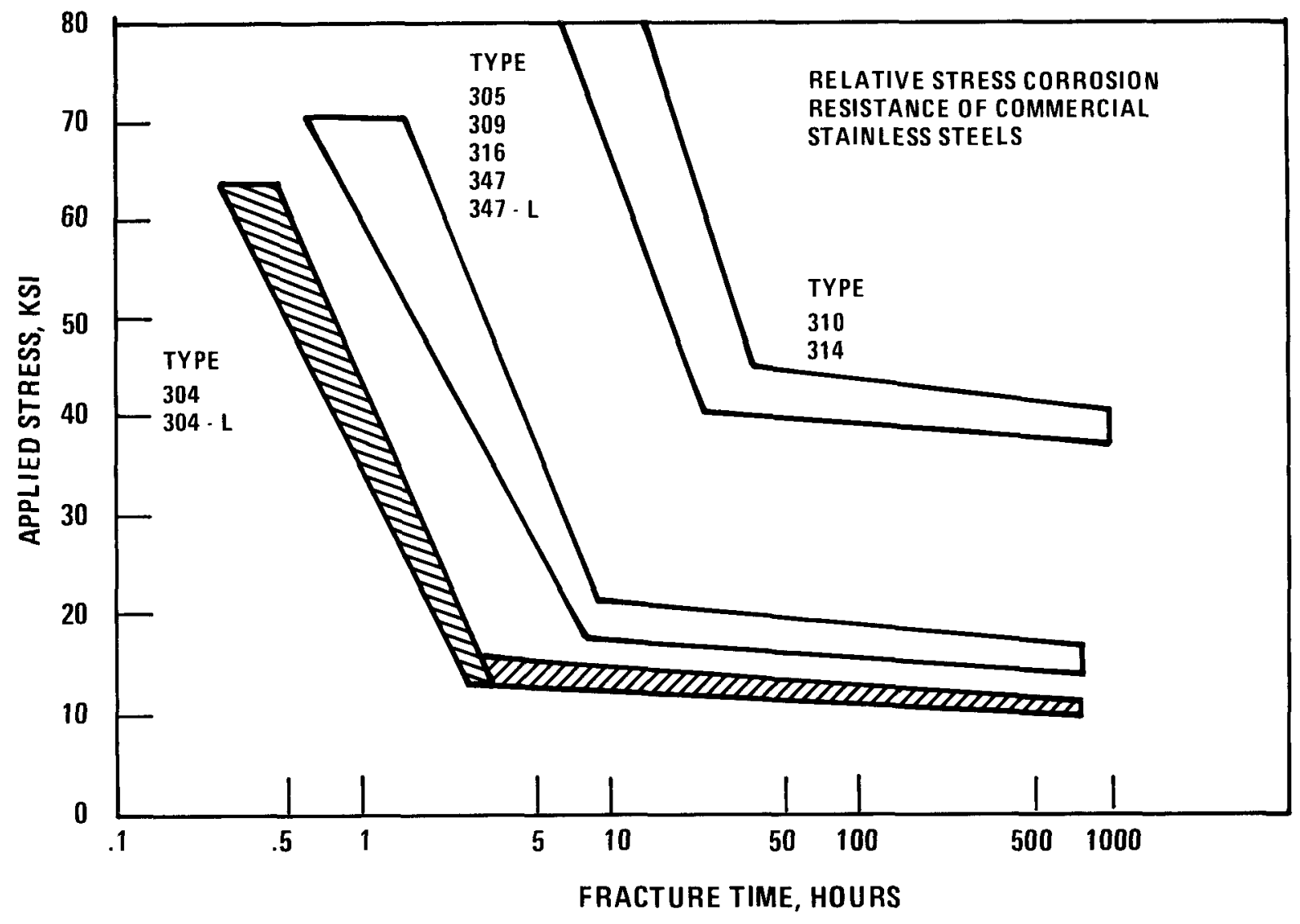

Figure 4.2-1. Composite Cunes Illustrating the Relative Stres Corrosion Cracking Resistance for Commercial Stainless Steels in Boiling 42 Percent Magnesium Chloride (Reference 33 ). 
It is probably best not to define a threshold stress for cracking but to specify a stress at which failure will not occur in a given time. cracking of austenitic materials has been observed at stresses as low as $3000 \mathrm{psi}$ in aqueous environments and $1000 \mathrm{psi}$ in steam environments. (35) However, Staehle ${ }^{(36)}$ reported that stress level in the range of $60 \%$ to $120 \%$ of the yield strength has little effect on the cracking of Type 304 stainless steel in $\mathrm{MgCl}_{2}$ solutions. Birchon and Booth ${ }^{(37)}$ found that an apparent threshold strain existed for Type 304, 316, and 321 stainless steels in the steam phase above an aerated $5 \mathrm{ppm} \mathrm{Cl}^{-}$solution, and the results are shown in Figure 4.2-2. The fact that cracking has occurred at such low stresses indicates that an attempt to lower residual and operating stresses to stop stress corrosion cracking would be unrealistic. However, tensile stresses should be kept as low as possible to minimize the potential for SCC occurrence.

\subsubsection{The Effect of Chloride Ion Concentration}

The effect of increasing the chloride concentration is to accelerate the cracking. Edeleanu's data ${ }^{(35)}$ also include a temperature effect of $\mathrm{MgCl}_{2}$ concentration on the cracking Type 304 and 321 type stainless steels as shown in Figure 4.2-3. In solutions of $\mathrm{NaCl}$, Warren ${ }^{(38)}$ investigated the effect of chloride concentration on the cracking of Type 304 stainless steel at $100^{\circ} \mathrm{C}$, and the results are shown in Figure 4.2-4. The results show a marked effect over three orders of magnitude of chloride concentration from 1500 to $10 \mathrm{ppm}$. Birchon and Booth ${ }^{(37)}$ reported that a concentration mechanism is required to crack austenitic stainless steels in $10 \mathrm{ppm} \mathrm{C}^{-}$(which was air saturated at room temperature) at $200-300^{\circ} \mathrm{C}$. The specimens used in these experiments were four point bent beam specimens with half of the specimen immersed and half above the liquid, cracking always occurred just above the water line. It was also found that increasing the chloride content of the water decreased the apparent "threshold stress" for Type 304 stainless steel but had no effect on Type 316 stainless steel. On similar steels Shimose, et al ${ }^{(39)}$ found that increasing the chloride drastically reduced the stress at which cracking was observed for both Type 304 and Type 316 stainless steels at 180 and $250^{\circ} \mathrm{C}$. 


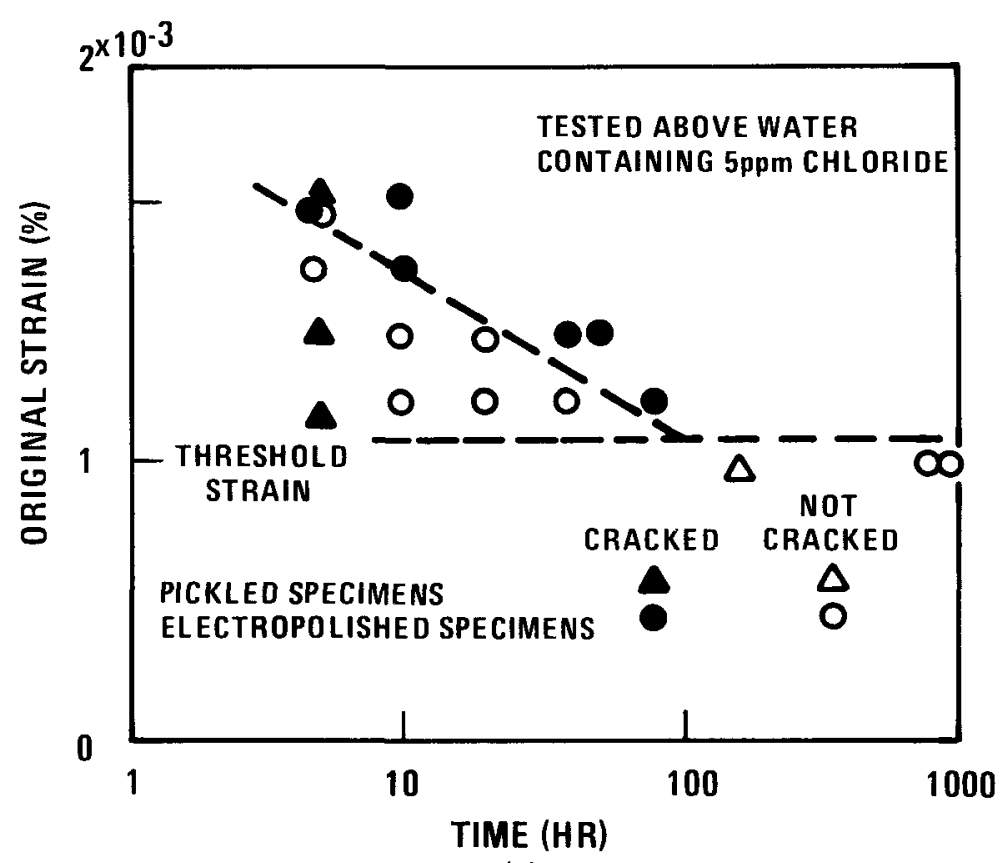

(a)

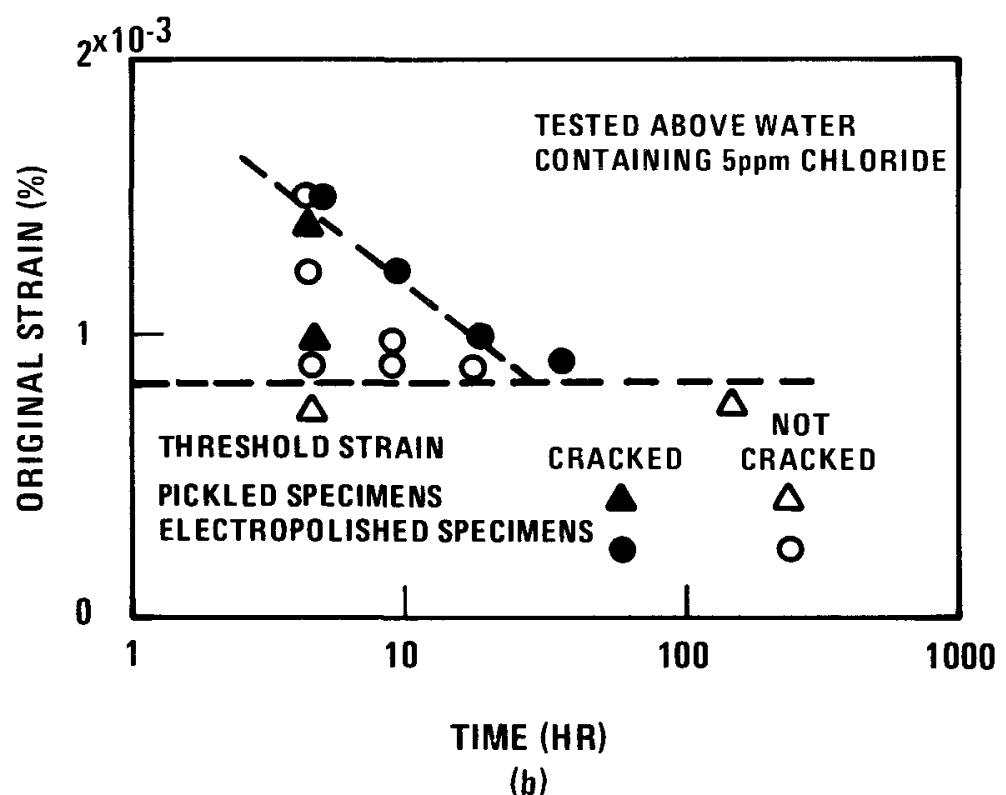

Figure 4.2-2. The Relationship Between Original Strain in Bent Beam Specimen and Time to Crack for (a) Type 321 Stainless Steel at $300^{\circ} \mathrm{C}$ and (b) Type 304 Stainless Steel at $200^{\circ} \mathrm{C}$ (Reference 37 ). 


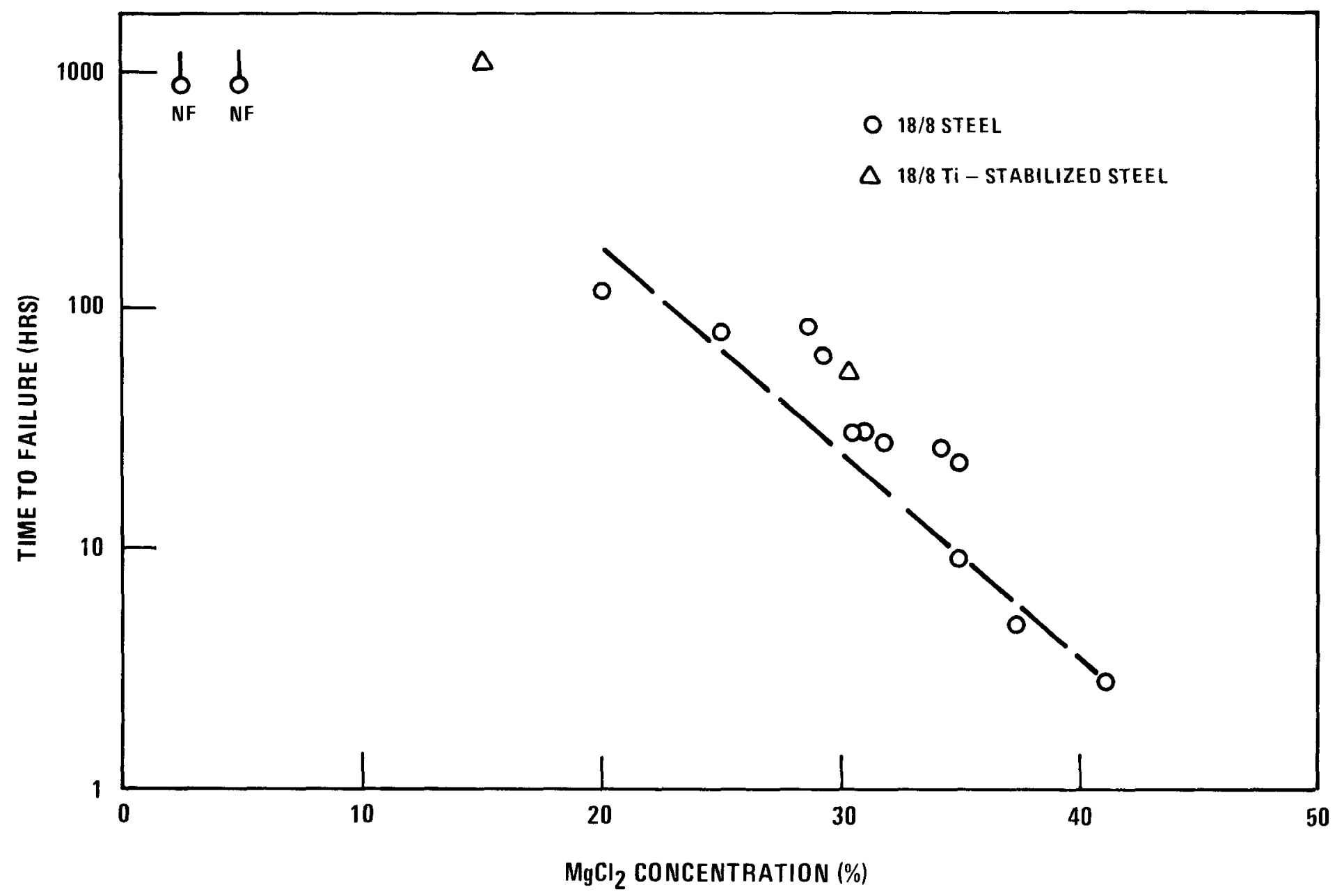

Figure 4.2-3. Effect of $\mathrm{MgCl}_{2}$ Concentration on Time to Failure (Reference 35 ). 


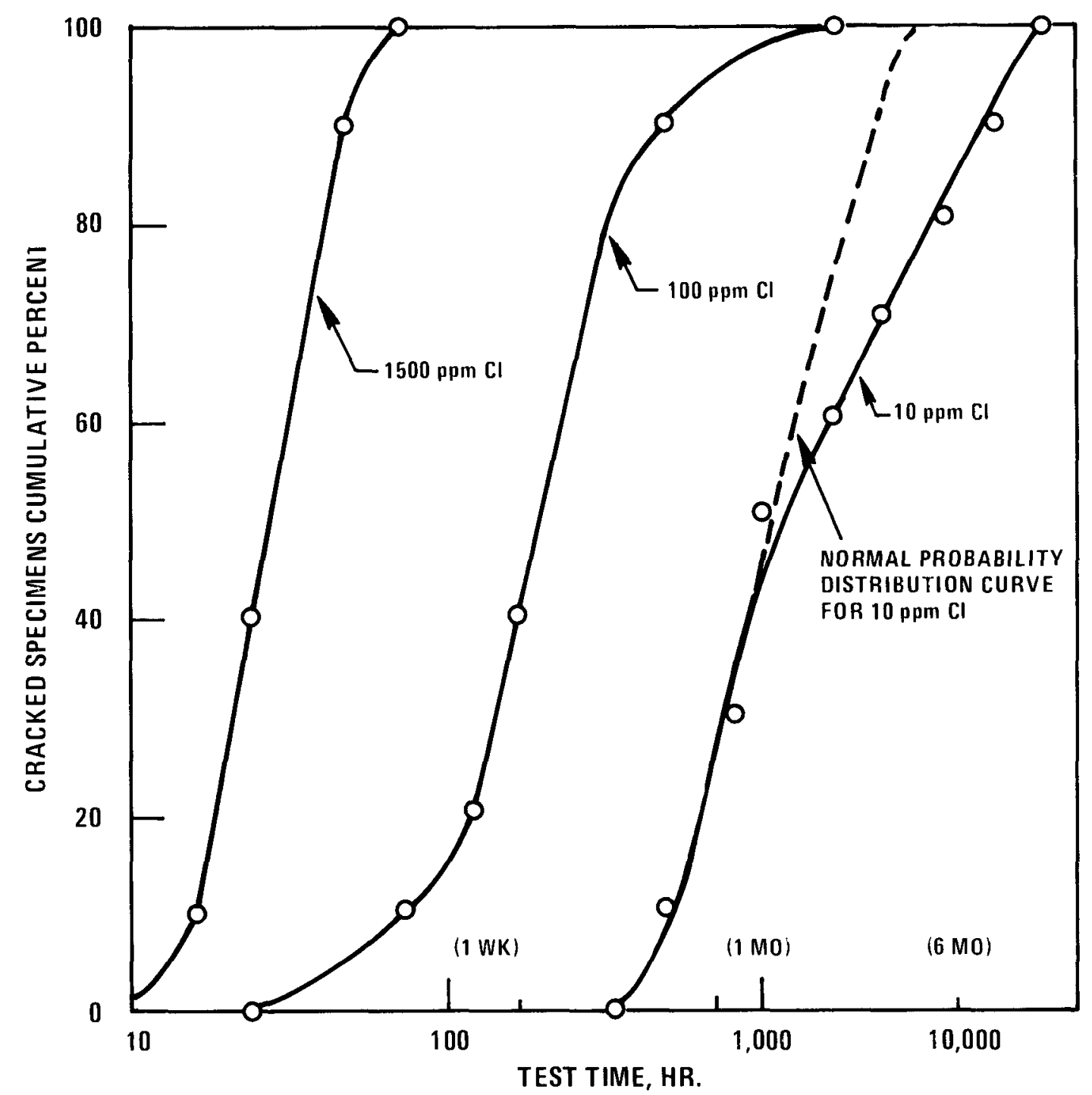

$\stackrel{w}{\sim}$

Figure 4.2-4. Effect of Chloride Concentration on the Time-for-Craching of Type 304 Stainlen Steel Specimens Exposed at $100^{\circ} \mathrm{C}$ 10 Chloride-Bearing Water (Reference 38). 
These authors also reported that the vapor phase was more aggressive than the liquid and that oxygen accelerated cracking. Neuman and Griess $(40)$ reported that little difference existed in the cracking susceptibility of the Type 347 stainless steel in solution containing between 25 and $100 \mathrm{ppm}$ chloride at $300^{\circ} \mathrm{C}$. However, with solutions containing $10 \mathrm{ppm}$ chloride the tendency of the steel to crack was much less. In fact, no cracks were visible after 2500-hour exposures.

\subsubsection{The Effect of Oxygen}

Shimose, et al ${ }^{(39)}$ reported that the presence of oxygen accelerated the cracking of Type 304 stainless steel in chloride solutions at 180 and $250^{\circ} \mathrm{C}$. However, Neuman and Griess ${ }^{(40)}$ found that for Type 347 stainless steel U-bend specimens, its susceptibility to cracking was not changed when the oxygen concentration was varied from $1200 \mathrm{ppm}$ to less than $1 \mathrm{ppm}$ in chloride solutions containing $100 \mathrm{ppm} \mathrm{Cl}^{-}$with $\mathrm{pH}$ values of ei ther 2.8 or 10.5 at $300^{\circ} \mathrm{C}$. Since cracking occurred so readily at 1 ppm oxygen concentration, this emphasizes how little oxygen is needed to produce cracking. Examination of the specimens showed that the number and appearance of cracks on the specimens were nearly the same at all oxygen levels. The fact that no evidence of cracking was found when all the oxygen was removed from the system with sodium sulfite agrees with the data reported by Williams $(41)$ and emphasizes that cracking occurs only when the chloride is accompanied by oxygen or perhaps by some easily reducible species.

Staeh $1 e^{(24)}$ has shown that oxygen has significant effects on the cracking of stainless steels at low chloride levels and a smaller effect at higher (1000 ppm) chloride levels.

\subsubsection{The Effect of $\mathrm{pH}$}

The effect of $\mathrm{pH}$ on the stress corrosion cracking of Type 304 stainless steel in boiling $\mathrm{MgCl}_{2}$ solutions has been the subject of numerous 
investigations. $(26,34,41,42)$ The results are all similar to those of Thomas et a1, (40) shown in Figure 4.2-5, where increasing pH level increases the time to failure. In solutions containing 50 to $100 \mathrm{ppm}$ chloride and starting pH values of $2.8,6.5$ or 10.5 at a test temperature of $300^{\circ} \mathrm{C}$ no effect of $\mathrm{pH}$ was discernable $\mathrm{e}^{(40)}$ as shown in Table 4.2-2. In $40 \% \mathrm{CaCl}_{2}$ solutions at $100^{\circ} \mathrm{C}$, Anderson ${ }^{(43)}$ found a minimum in the time to failure at approximately $\mathrm{pH} 7$ as shown in Figure 4.2-6. At pH 4 and below, he observed general corrosion. However, the general trend appears to be for higher $\mathrm{pH}$ levels to reduce the susceptibility to cracking.

\subsubsection{The Effect of Temperature}

Temperature has significant effect on the time to failure for a given system. Thomas, et a ${ }^{(42)}$ have shown a marked decrease in time to cracking with smal1 increases in temperature in a $\mathrm{MgCl}_{2}\left(37 \% \mathrm{Cl}^{-}\right)$solution, see Figure 4.2-7. Decreasing the chloride content increased the time to failure and decreased the effect of temperature. Similar data have been presented by Hoar and Hines ${ }^{(34)}$ and Koh1 ${ }^{(44)}$. All of these results follow a relationship of the type:

$$
t_{f}=A \exp (B / T)
$$

where

$$
\begin{aligned}
t_{f} & =\text { time to failure } \\
T & =\text { absolute temeprature } \\
A, B & =\text { constants }
\end{aligned}
$$

The effect of temperature on the time to cracking of Type 304 stainless steel in water solutions containing $100 \mathrm{ppm}$ chloride was reported by warren (23) and is shown in Figure 4.2-8. The cracking of Type 347 stainless steel occurred more readily at 150 to $250^{\circ} \mathrm{C}$ has been reported by Neuman and Griess $(40)$ in the temperature range of 75 to $300^{\circ} \mathrm{C}$. Similar results were obtained by Frey and Staehle ${ }^{(24)}$ for Type 304 stainless steel. 


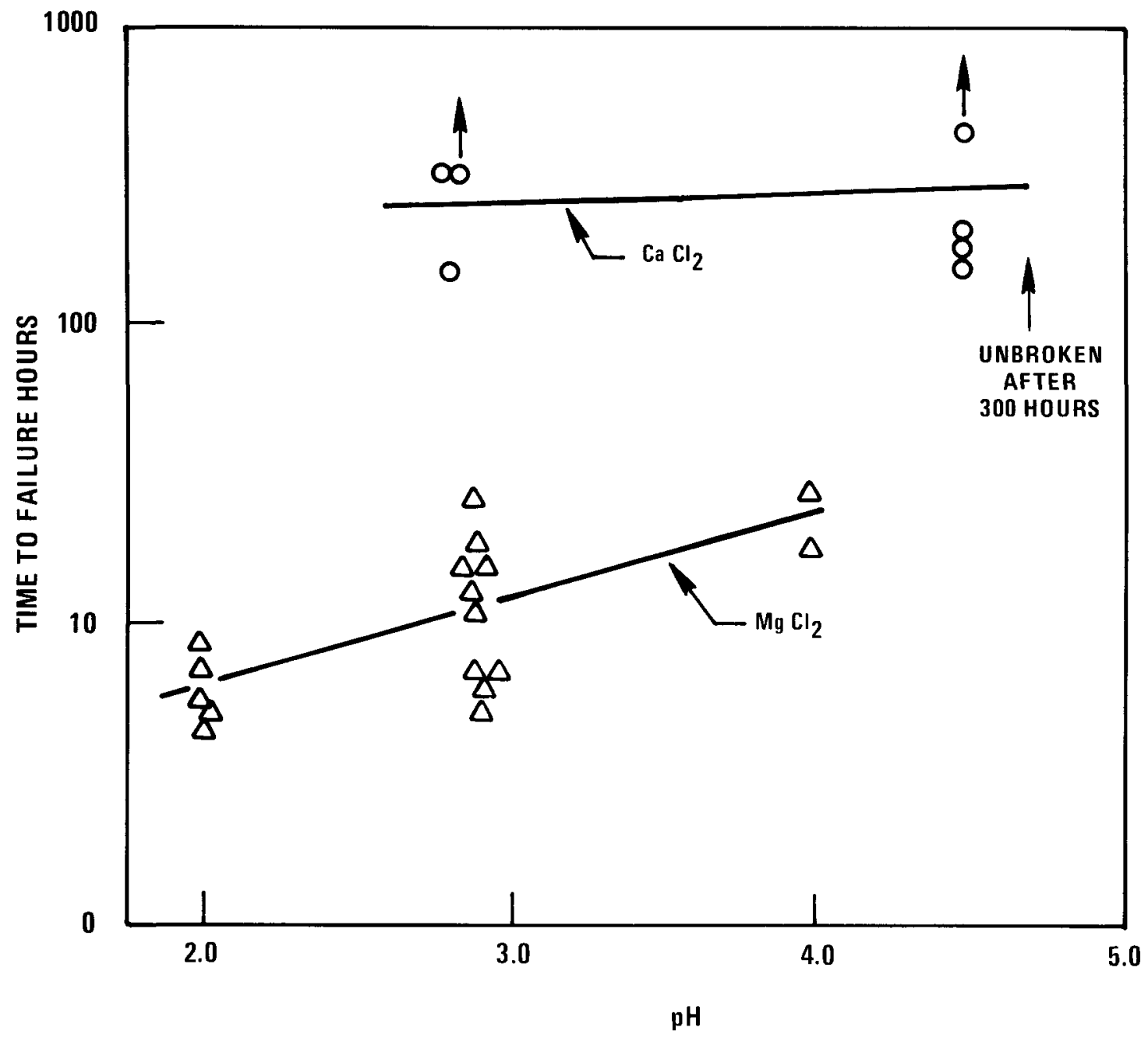

Figure 4.2-5. Effect of $\mathrm{pH}$ on the Time to Failure of Type 304 Stainless Steel at $50.000 \mathrm{psi}$ in $\mathrm{MgCl}_{2}$ and $\mathrm{CaCl}_{2}$ Solutions $\mathrm{Boiling}$ at $125^{\circ} \mathrm{C}$ (Reference 42 ). 
TABLE $4.2-2$

EFFECT OF PH ON STRESS CORROSION CRACKING OF TYPE 347

STAINLESS STEEL AT $300^{\circ} \mathrm{C}(40)$

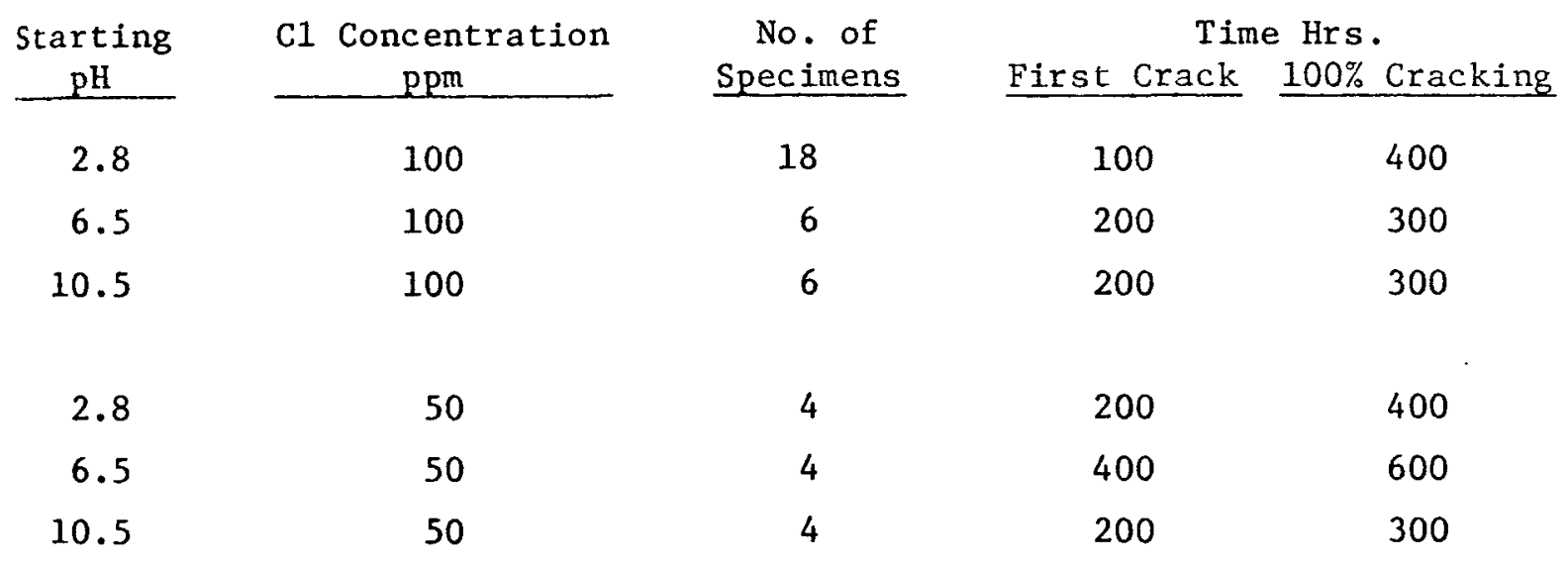

\subsubsection{The Effect of Metallic Cations}

Warren ${ }^{(38)}$ reported that the time to cracking increases in the order $\mathrm{MgCl}_{2}, \mathrm{FeCl}_{3}, \mathrm{CaCl}_{2}, \mathrm{NaCl}$, as shown in Figure 4.2-9. It has been suggested that the effect of different metallic cations on the time to cracking of austenitic stainless steels in chloride solutions is attributable to their effect on solution $\mathrm{pH}$. A similar trend, $\mathrm{MgCl}_{2}, \mathrm{CaCl}_{2}, \mathrm{LiCl}_{2}$ was observed by Thomas, et a ${ }^{(42)}$ which is also the order of increasing $\mathrm{pH}$. However, the latter workers conducted tests in $\mathrm{CaCl}_{2}$ and in $\mathrm{LiCl}$ at two differenct $\mathrm{pH}$ levels and found no effect of $\mathrm{pH}$ and thus attributed the different times to failure to cation rather than $\mathrm{pH}$ effects. Couper ${ }^{(45)}$ conducted tests on Type 304 stainless stee 1 in various chloride solutions and found that the major effect was due to chloride ion concentration with little effect due to metallic cation. Table 4.2-3 shows selected data from 


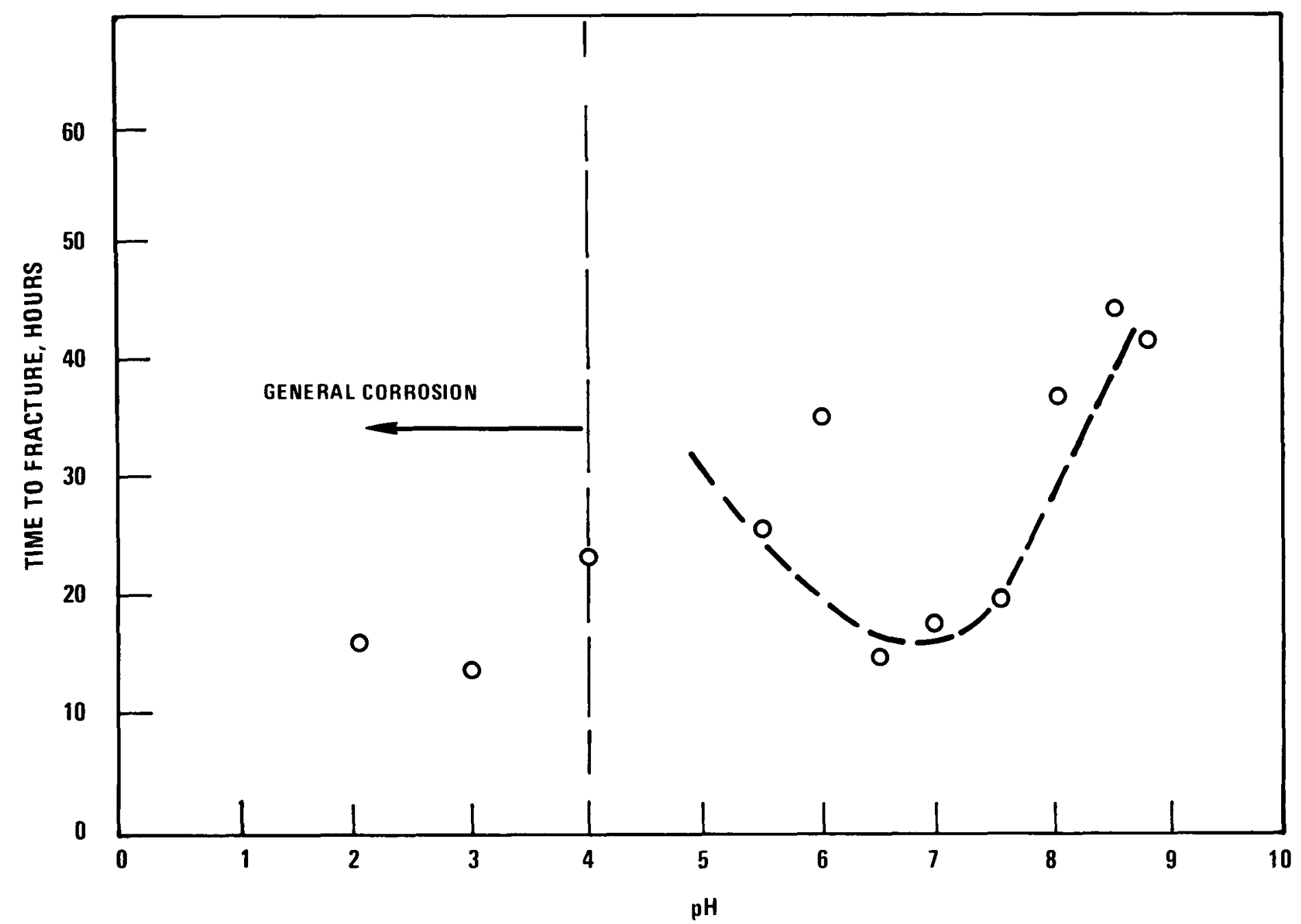

Figure 4.2-6. Effect of $\mathrm{pH}$ on Time to Failure of $18-8$ Stainless Steel in $40 \% \mathrm{CaCl}_{2}$ Solution at $100^{\circ} \mathrm{C}$ (Reference 43 ). 


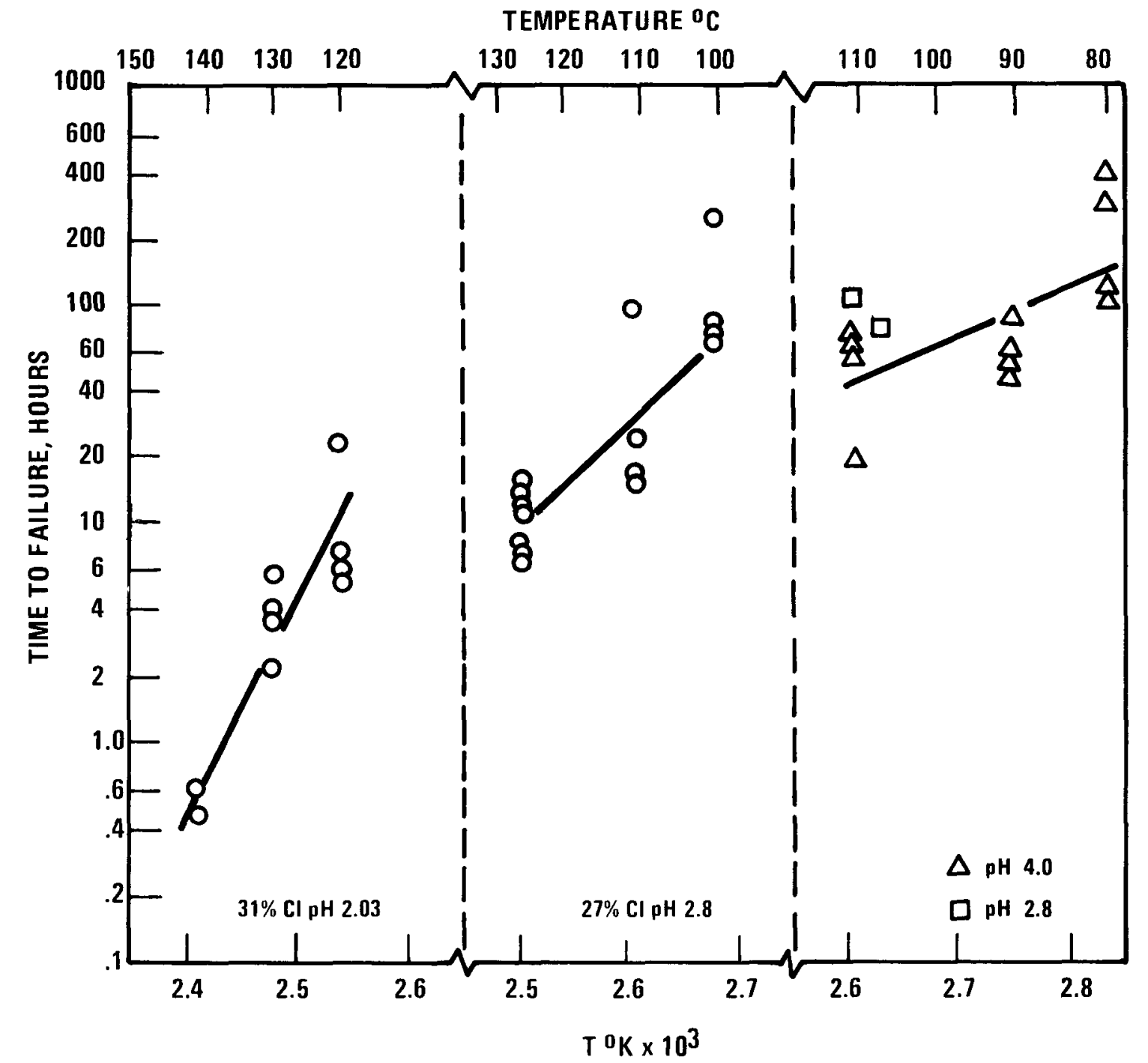

Figure 4.2-7. Effect of Temperature on Time to Failure of Type 304 Stainless Steel at $50.000 \mathrm{psi}$ in $\mathrm{MgCl}_{2}$ Solution of Various Chloride Ion Concentrations (Reference 42). 
Couper's work and summarized by Soo. (1) In addition to the cracking in the chlorides shown in this table, cracking has been observed in $\mathrm{C}_{2} \mathrm{H}_{5} \mathrm{Cl}+0.5 \% \mathrm{H}_{2} \mathrm{O},{ }^{(46)} \mathrm{CdCl}_{2},{ }^{(47)} \mathrm{CuCl}_{2}$, (48) $\mathrm{FeCl}_{3}$, (38) $\mathrm{HgCl}_{2}$, (46) $\mathrm{LiCl}$, and $\mathrm{ZnCl}_{2}$. ${ }^{(49)}$ The significant point about the cracking of sensitized Type 304 stainless stee 1 in $\mathrm{C}_{2} \mathrm{H}_{5} \mathrm{Cl}{ }^{(46)}$ is that water must be present. Couper $(45)$ also found that water was necessary to crack Type 304 stainless steel in $\mathrm{MgCl}_{2}$.

\subsubsection{The Effect of Alloy Composition}

The most well known curve summarizing the data for the effect of nickel on the chloride induced stress corrosion cracking of $\mathrm{Fe}-18 \% \mathrm{Cr}$ alloys is that shown in Figure 4.2-10 as reported by Copson. $(50)$ Based on the results shown in the figure, it is reasonable to conclude that the zero nickel ferritic and martensitic alloys and alloys with more than 45-50\% nickel should be resistant to chloride cracking. However, for $12 \% \mathrm{Cr}$ martensitic steels, its cracking resistance in a chloride environment is dependent on the final tempering temperature $(51)$ as shown in Figure 4.2-11. This figure shows that 410 stainless steel tempered at approximately $565^{\circ} \mathrm{C}$ and above is resistant to cracking in chlorides, and that when tempered in the region of $455^{\circ} \mathrm{C}$ it is very susceptible to cracking in chlorides. However, this could be due to the structural changes brought up by tempering. The second conclusion that higher nickel alloys are immune to cracking in chlorides should be modified, because high nickel alloys such as Inconel 600 has been reported to crack even in high purity water. ${ }^{(52)}$ Royuela and Staehle ${ }^{(36)}$ reported that Incone 718 which contains $50-55 \% \mathrm{Ni}$ is still susceptible to cracking in chlorides. This may be due to the precipitation of $\gamma$ phase, $\mathrm{Ni}_{3}(\mathrm{Al}, \mathrm{Ti})$, which leads to the reducing of nickel content of the alloy matrix. Table 4.2-4 shows the effect of increasing nickel content on the time to cracking. (52) The data shown in Figure 4.2-10 also reflect the effect of increasing nickel content. 


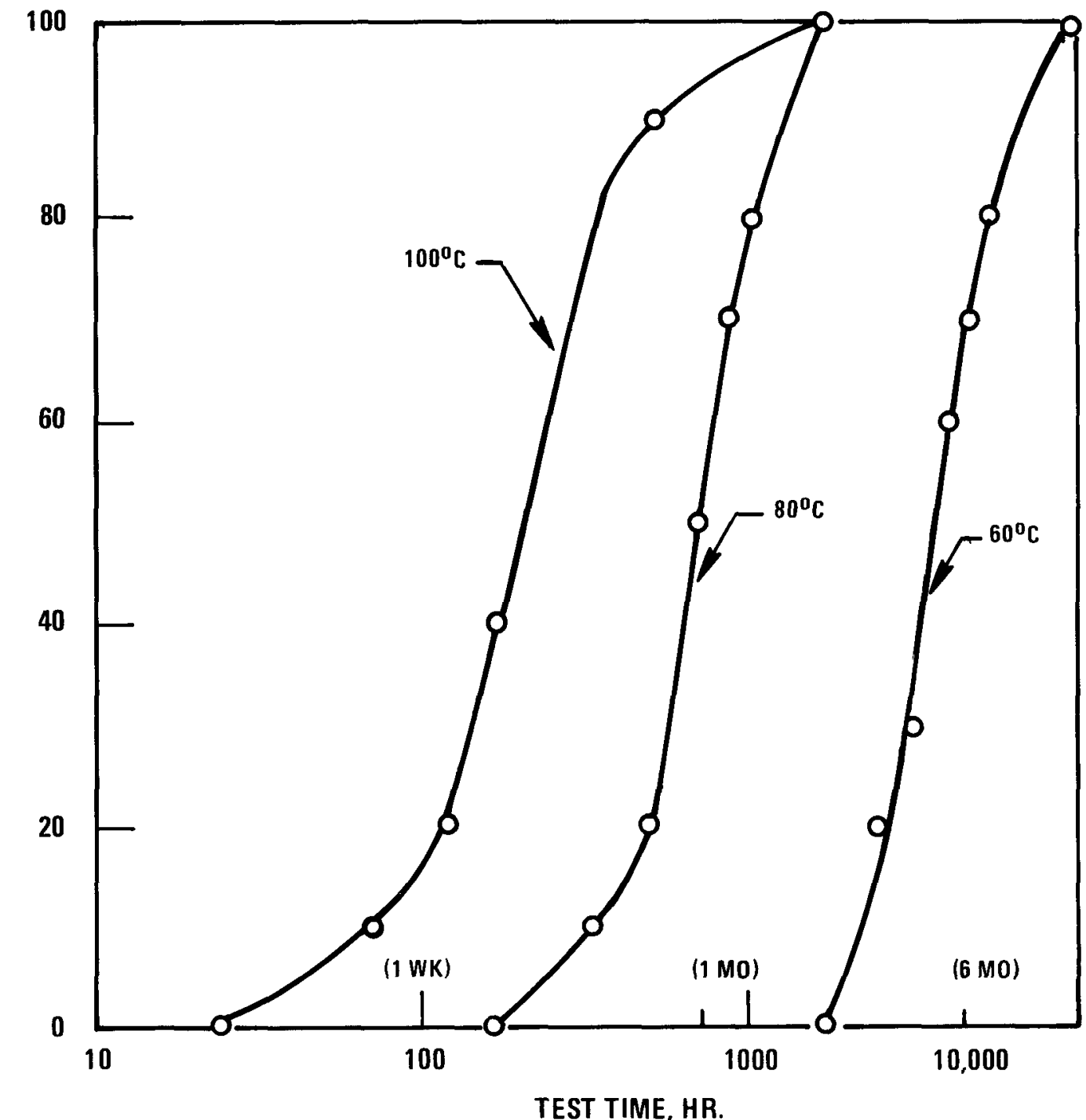

Figure 4.2-8. Effect of Temperature on the Time-for-Cracking of Type 304 Stainless Steel Specimens Exposed to Water Containing 100 ppm Chloride (Reference 23). 


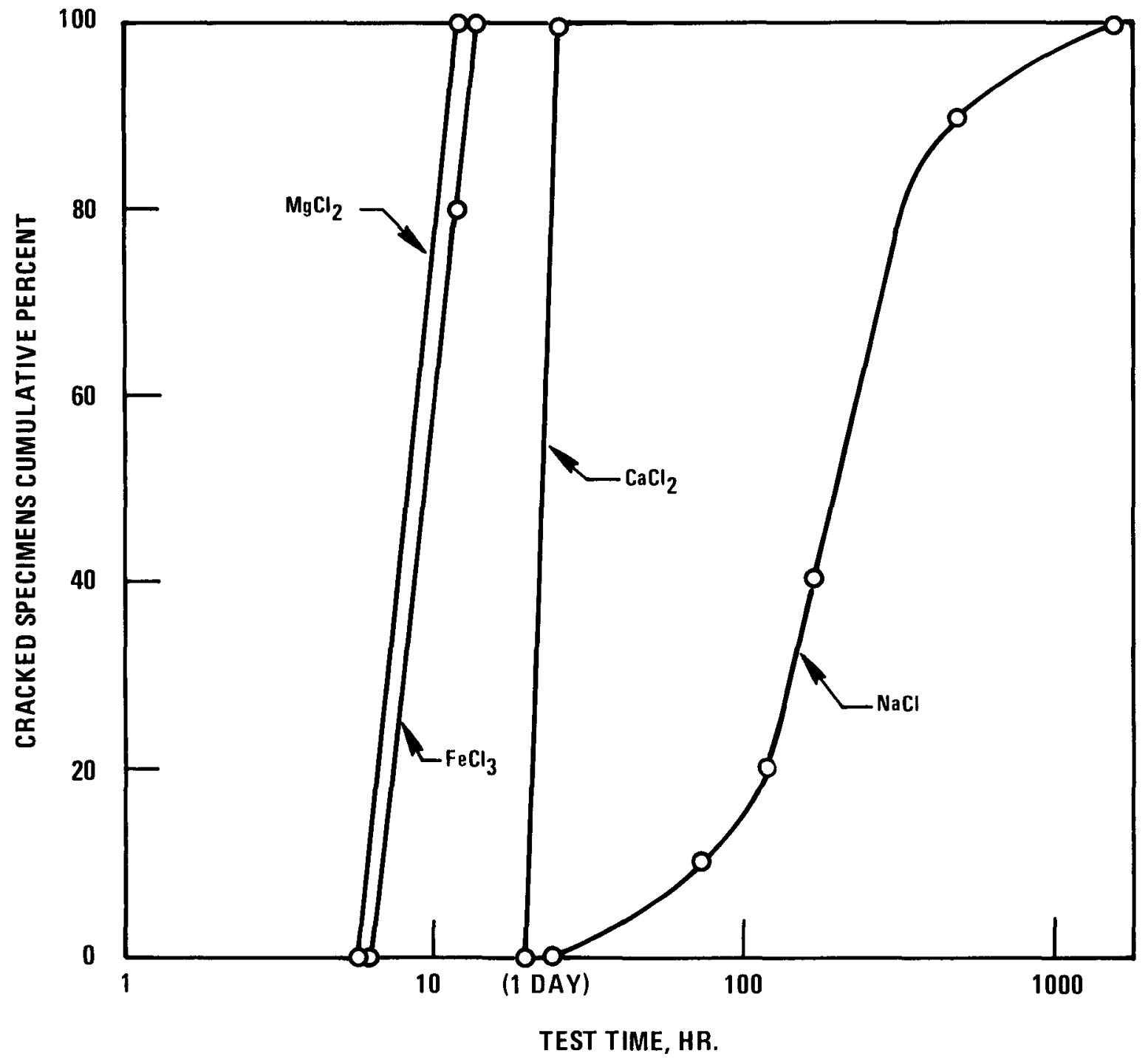

Figure 4.2-9. Effect of Metallic Cation on the Time-for-Cracking of Type 304 Stainless Steel Specimens Exposed at $100^{\circ} \mathrm{C}$ to Water Containing $100 \mathrm{ppm}$ Chloride (Reference 38 ). 
TABLE $4.2-3$

STRESS CORROSION CRACKING OF TYPE 304 IN DIFFERENT

CHLORIDE SOLUTIONS AT A CONCENTRATION OF

$18.7 \mathrm{~g} \mathrm{Cl}^{-} / 100 \mathrm{~g} \mathrm{H}_{2} \mathrm{O}^{(1)}$

\begin{tabular}{lccc}
$\begin{array}{c}\text { Type of } \\
\text { Chloride }\end{array}$ & $\begin{array}{c}\text { Temp } \\
{ }^{\circ} \mathrm{F}\end{array}$ & $\begin{array}{c}\text { Hours } \\
\text { to Crack }\end{array}$ & $\begin{array}{c}\text { No. of } \\
\text { tests }\end{array}$ \\
\cline { 2 - 2 }${ }_{2}$ & $280-290$ & $8 \cdot 2 \rightarrow 16 \cdot 0$ & 9 \\
$\mathrm{CeCl}_{2}$ & 220 & $46 \cdot 1$ & 1 \\
$\mathrm{NaCl}$ & 285 & 13 & 1 \\
$\mathrm{NH}_{4} \mathrm{Cl}$ & $260-290$ & $12 \cdot 3-23 \cdot 1$ & 4 \\
$\mathrm{CoCl}_{2}$ & $260-300$ & $13 \cdot 3-26 \cdot 8$ & 4 \\
$\mathrm{CaCl}_{2}$ & $270-300$ & $18 \cdot 2-20 \cdot 5$ & 2 \\
$\mathrm{SnCl}_{2}$ & 290 & $19 \cdot 1$ & 1 \\
& 310 & $18 \cdot 7$ & 1 \\
$\mathrm{KCl}$ & 280 & $30 \cdot 9$ & 1 \\
$\mathrm{NiCl}_{2}$ & $280-290$ & $30 \cdot 2-39 \cdot 3$ & 2 \\
$\mathrm{BaCl}_{2} \cdot 2 \mathrm{H}_{2} \mathrm{O}$ & 235 & .58 & 1 \\
& 283 & $66 \cdot 5$ & 1
\end{tabular}

The effect of chromium content is more complicated, because its effect is dependent on the nickel content of the alloy. Truman and Perry ${ }^{(53)}$ conducted tests on various $\mathrm{Fe}-\mathrm{Cr}-\mathrm{Ni}$ alloys in different chloride solutions; some of their results were summarized by Soo $(1)$ and shown in Figure 4.2-12. Similar results for $\mathrm{Fe}-10 \% \mathrm{Ni}+\mathrm{Cr}$ alloys were reported by Royue $7 \mathrm{a}$ and Staehle, ${ }^{(36)}$ in that the $\mathrm{Fe}-10 \% \mathrm{Ni}-20 \% \mathrm{Cr}$ alloy exhibited poor resistance to attack while alloys containing 5 to $12 \%$ cr did not crack. 


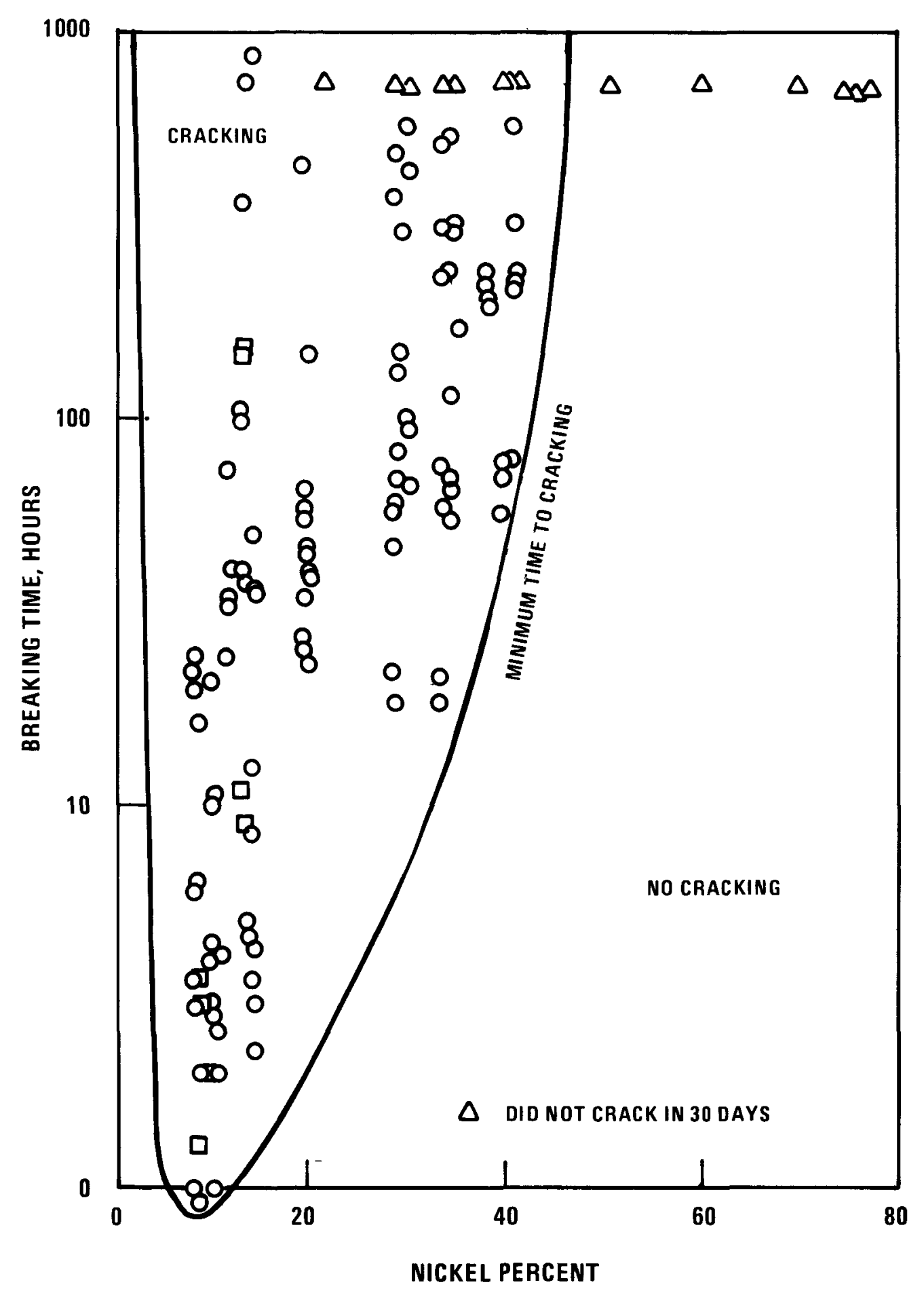

Figure 4.2-10. Effect of Increasing the Nickel Content on the Susceptibility of Fe-Cr-Ni Wires in Boiling $42 \% \mathrm{MgCl}_{2}$ (Reference 50 ). 


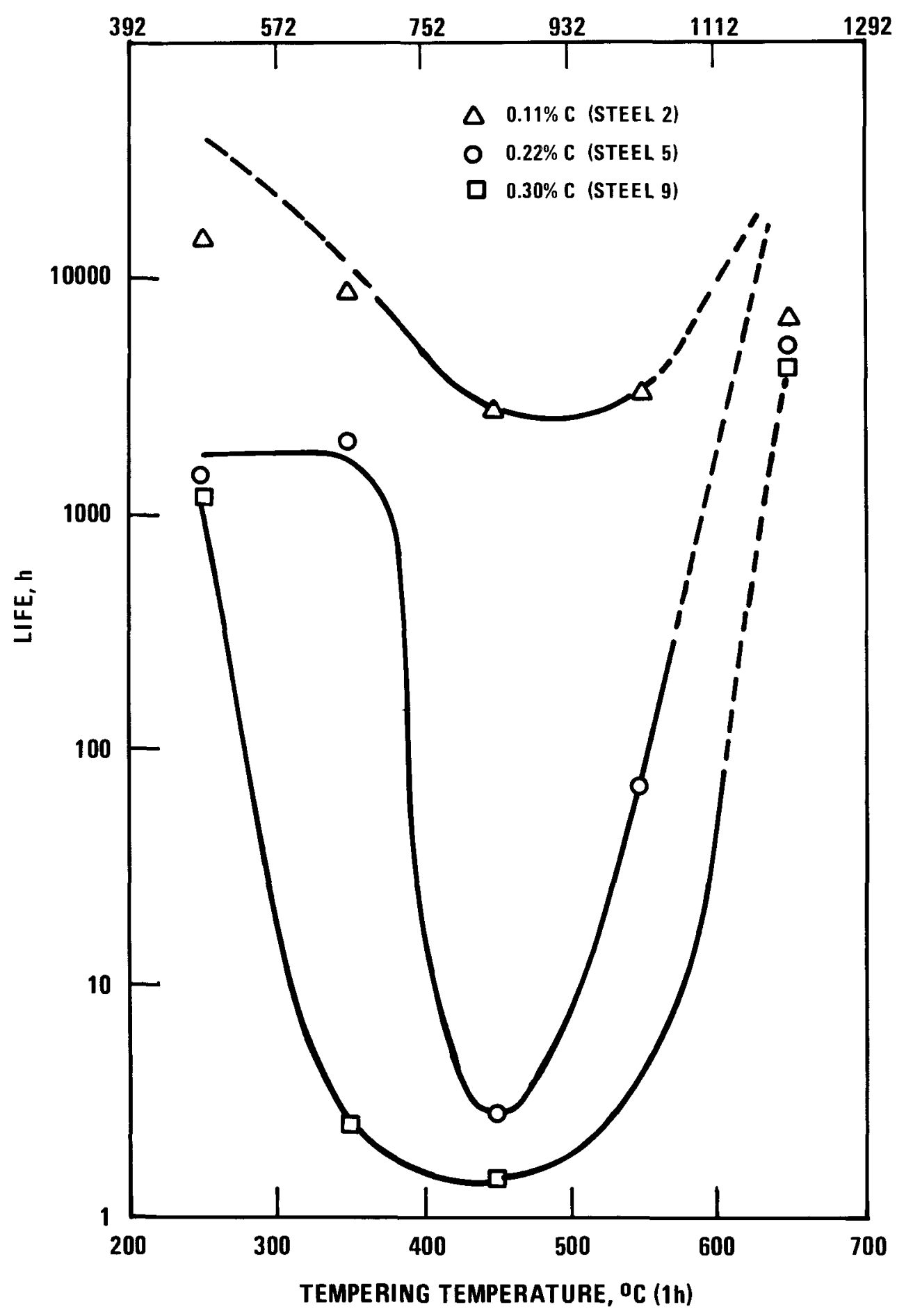

Figure 4.2-11. The Effect of Tempering Temperature on the Cracking of $13 \% \mathrm{Cr}$ Steels in $3 \%$ $\mathrm{NaCl}$ at Room Temperature (Reference 51 ). 

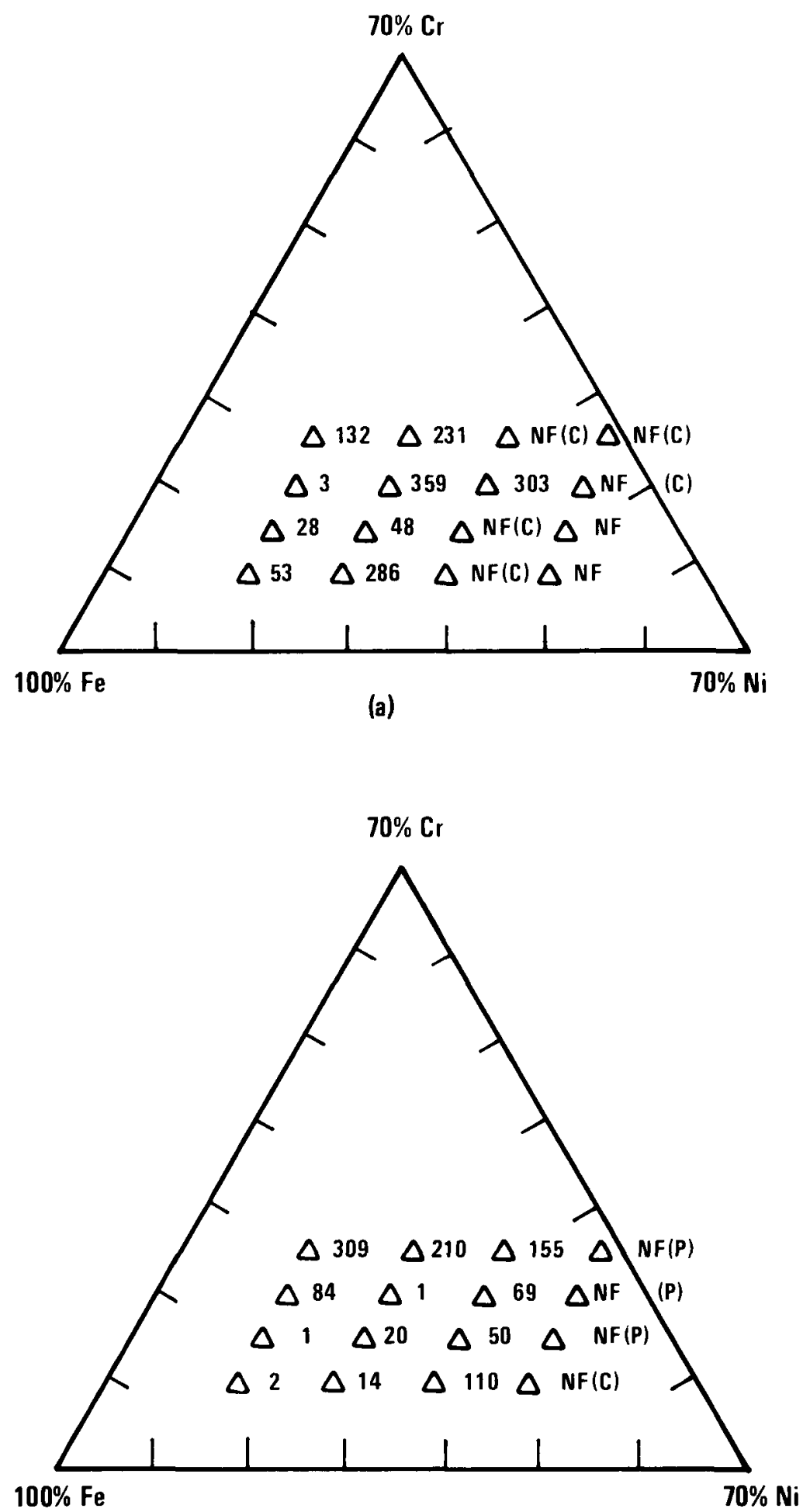

(b)

Figure 4.2-12 Time to Failure in Hours for Alloys as Shown Above in: (a). Boiling 42', $\mathrm{MgCl}_{2}$ at 40.000 psi. (b) $3^{\prime}, \mathrm{NaCl}$ at $250 \mathrm{C}^{\prime} 2000 \mathrm{psi}_{2}$ and $20.000 \mathrm{psi} \mathrm{NF}-n o t$ Failed in $500 \mathrm{Hr}$.: $N F(C)$-not Failed but Cracked. NF(P)-not Failed but Pitted (Ref. 1). 
Van Rooyen (55) showed that a $1.5 \%$ Mo addition to a $16 \mathrm{Cr}-20 \mathrm{Ni}$ alloy makes the alloy very susceptible to cracking as shown in Figure 4.2-13. Similar deleterious effects have been observed by Hoar and Hines. (56) Truman and Perry ${ }^{(53)}$ found no significant effect of Mo additions to $\mathrm{Fe}-15-45 \% \mathrm{Ni}-15 \% \mathrm{Cr}$ alloys. The superior performance of Type 316 compared to Type 304 stainless steel in Figure 4.2-3 may be attributed to the higher nickel content outweighing the deleterious effect of molybdenum.

The effect of stabilizing elements, titanium and niobium, appears to be to increase the susceptibility of stainless steels to chloride induced stress corrosion cracking. $(56-58)$ Barnartt, et al ${ }^{(58)}$ have shown that the addition of $0.54 \% \mathrm{Ti}$ to an immune $\mathrm{Fe}-20 \mathrm{Ni}-16 \mathrm{Cr}$ alloy produced susceptibility. Uhlig and White ${ }^{(59)}$ found that niobium additions were deleterious. Hoar and Hines ${ }^{(56)}$ found that at higher stresses, $18 \% \mathrm{Cr}-10 \% \mathrm{Ni}-1 \% \mathrm{Nb}$ alloy had longer times to failure than an 18-8 stainless steel but that this trend was reversed at lower stresses as shown in Figure 4.2-14. It is also noted that the $\mathrm{Nb}$ stabilized material is better than the Ti containing material.

The effects of nitrogen and carbon on the stress corrosion cracking of austenitic stainless steels in chloride environments were reported by Bade and Dodd. (54) They found that steels which intrinsically are either highly crack-susceptible or highly crack-resistant are little affected by higher interstitial contents. Steels of intrinsically moderate crack resistance are made more crack-prone by nitrogen additons and rather less crack prone by carbon addition. Transmission electron metallography indicates that these interstitials may exert significant influences on the defect structure, depending on the initial stacking fault energy, but the overall correlation between defect structure and stress cracking propensity is poor. Since carbon and nitrogen seem to exert their greatest effect in the region of the $\mathrm{Fe}-\mathrm{Cr}-\mathrm{Ni}$ phase diagram where austenitic is unstable, it is suggested that these elements play some important role in the structural stability of alloy atoms at crack tip. 


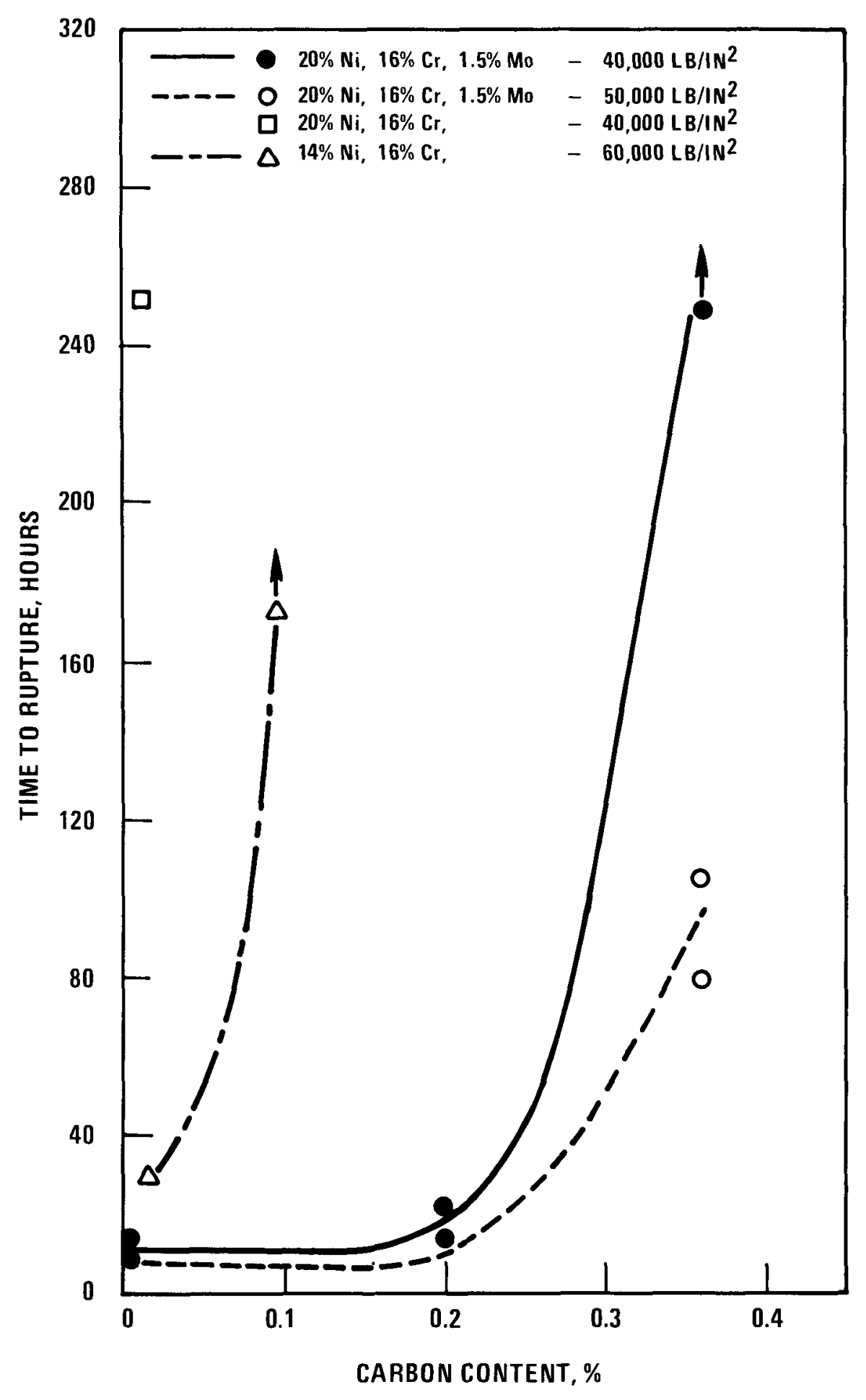

Figure 4 2-13. Effect of Carbon on Times to Failure of Stainless Steel in Boiling $\mathrm{MgCl}_{2}$ (Reference 55). 


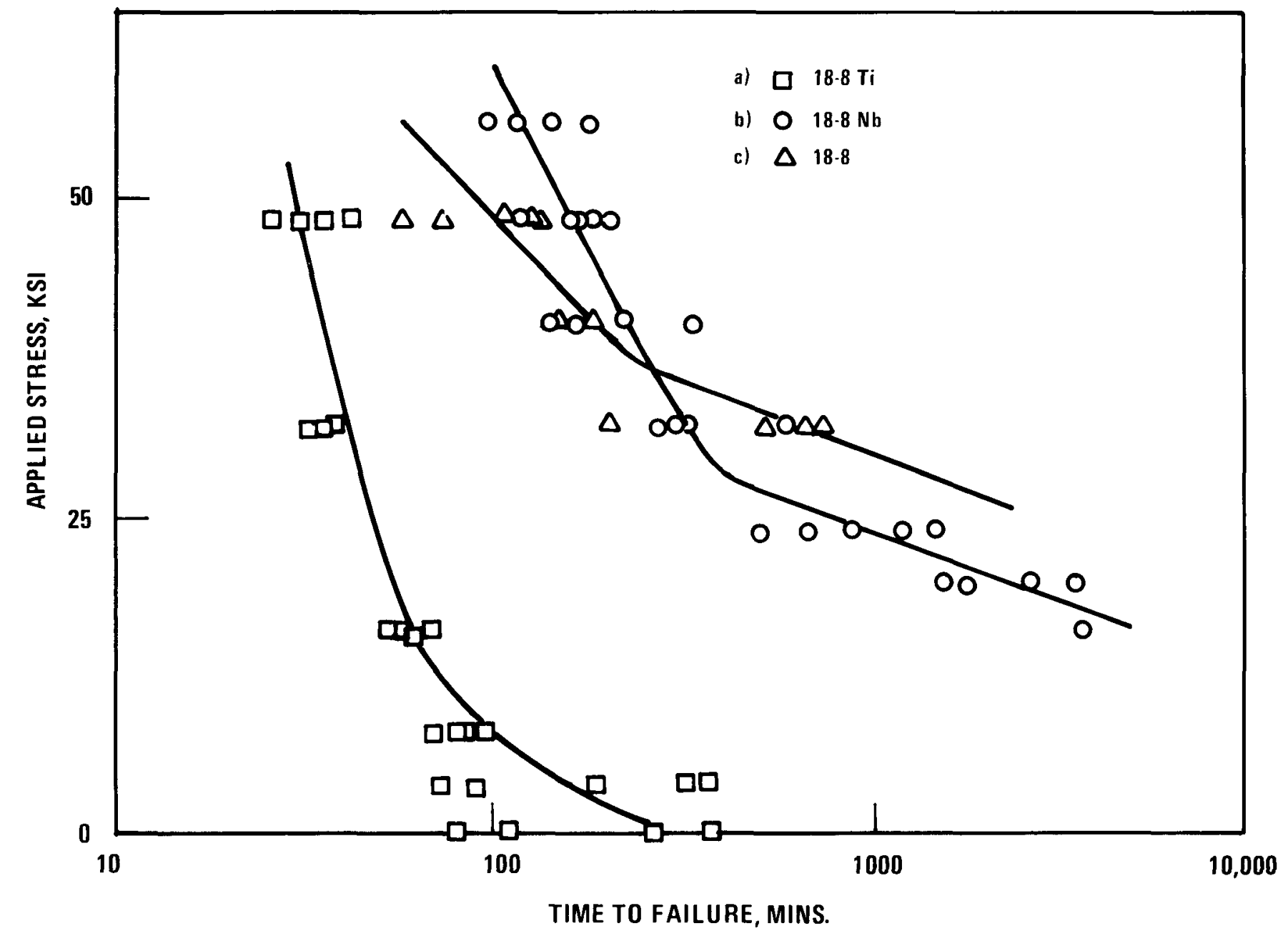

Figure 4.2-14. The Effect of Titanium and Niobium on the Stress Time to Failure Curve of $18-8$ Stainless Steels (Reference 56 ). 


\subsubsection{Conclusion}

The austenitic stainless steels are all susceptible to chloride induced stress corrosion cracking. Within the lillits of composition allowed for these alloys probably very little can be done to significantly improve their resistance to SCC. The use of high carbon grades will give a higher creep strength to these alloys and may slightly improve the SCC resistance. However, nitrogen and other impurities should be kept as low as possible while a higher silicon content may be uscful.

If stabilized stainless steels are to be used, it appears that $\mathrm{Nb}$ is better than $\mathrm{Ti}$ as a stabilizing addition. Inconel alloys are in general more resistant to chloride induced SCC. In the case of Inconel 600 it was observed that a fairly long incubation period is required for the initiation of SCC. In addition, cast structures, such as weldments, appear to be more resistant than wrought materials, but care must be taken in welding as the process can induce a greater susceptibility in the base metal.

Although the grain size has relatively little effect on cracking, but larger grain sizes are marginally better. Whether the sensitized structure causing SCC of the austenitic stainless steels is not clear at the present time, but it nevertheless accelerates cracking. Consequently, sensitization caused during fabrication, welding, heat treating, and service should be avoided if possible.

\subsection{Cracking of Fe-Cr-Ni Alloys in Fluoride Environment}

Intergranular attack of sensitized austenitic stainless steel by water containing fluoride ions was reported by Ward et al. (84) The attack limited to specimens of the Types 304 and 316 stainless steels with heavily sensitized microstructure, known to result from extensive grain boundary chromium depletion. As expected from earlier investigations, $(85,86)$ there was no trace of $\mathrm{F}^{-}$attack in annealed material. Nor 
did the testing conditions produce any significant "weld decay" in heated zones adjacent to the weld beads deposited on a number of heats of annealed Type 304 stainless steel base metal. Extensive metallographic study of corroded specimens demonstrated that $\mathrm{F}^{-}$attack was purely intergranular. There was no evidence of transgranular branching, mixed mode or pitting attack, which frequently occur during $\mathrm{Cl}^{-}$stress corrosion of sensitized Type 304 stainless steel.

They also observed that the attack was consistently less severe on materials of finer grain size and/or lower carbon content. Specimens of other materials, such as Inconel 600, Incoloy 800, fine grained Types $304 \mathrm{~L}$ and 347 stainless steels, and austenitic-ferritic weld deposits for castings, appeared to be completely resistant to $\mathrm{F}^{-}$attack after a sensitizing heat treatment at $621^{\circ} \mathrm{C}\left(1150^{\circ} \mathrm{F}\right)$ for 10 to 24 hours.

Unlike the attack of the Strauss and Huey Tests, the $\mathrm{F}^{-}$attack did not occur over the entire surface of the specimen; and the data indicate that at least one or more of the following conditions is a prerequisite for attack: (1) tensile stress, applied or residual; (2) cold work, with or without appreciable residual macro stress; (3) a crevice; (4) visible oxide film formed by elevated temperature exposure in air. Attack occurred at room temperature and was more rapid at $82^{\circ} \mathrm{C}\left(180^{\circ} \mathrm{F}\right)$. It was observed that at this temperature, concentrations less than $1 \mathrm{ppm}$ $\mathrm{F}^{-}$in the bulk solution caused attack in crevices. A very high concentration $(4 \mathrm{w} / \mathrm{o} \mathrm{NaF})$ was not corrosive. Rate and mode of $\mathrm{F}^{-}$attack was not affected by amount of $\mathrm{Cl}^{-}$in the corrosive solution over a range of about $15 \mathrm{ppm}$ to less than $30 \mathrm{ppb}$.

Among the many potential sources of $\mathrm{F}^{-}$contamination are the residue from slag shielded welding operations and the fluoride compound-containing fluxes. Both the weld fumes, deposited on the base metal, and the welding slag release $\mathrm{F}^{-}$at a slow rate over a lengthy time period when wetted, and may result in attack of sensitized material. When an electrode coating 
contains the normal fluoride content, corrosion occurs regardless of presence or absence of $\mathrm{Fe}, \mathrm{Cr}, \mathrm{Mn}$, or $\mathrm{Ni}$ in the corrosive fumes deposited on the alloys. Identical $\mathrm{F}^{-}$attack also occurred when absolutely clean, unwelded materiāl was exposed to deionized water solutions of high purity reagents such as $\mathrm{NH}_{4} \mathrm{~F}, \mathrm{NaF}$, and $\mathrm{KF}$ which contained less than $10 \mathrm{ppm} \mathrm{Cl}^{-}$. Similar corrosive effects of coated welding electrode flux and fumes on Type 304 stainless steel was also reported by Pickett and Walker.

\subsubsection{Corrosion of $\mathrm{Fe}-\mathrm{Cr}-\mathrm{Ni}$ Alloys In $\mathrm{HNO}_{3}$ - $\mathrm{HF}$ Solutions}

The aqueous processing of nuclear power reactor fuels that contain separate phases of $\mathrm{PuO}_{2}$ or $\mathrm{ThO}_{2}$ requires dissolvents other than simple nitric acid. In order for the resulting solutions to be processed by welldeveloped nitric acid solvent extraction techniques, the final solution should still be predominantly nitrate. The usual approach to the problem has been to add varying amounts of fluoride to the nitric acid dissolvent to increase dissolution rates and solubilities of the fuel components. However, the introduction of fluoride causes severe corrosion problems of conventional materials of construction.

A survey of the corrosion of selected alloys in $\mathrm{HNO}_{3}-\mathrm{HF}$ solutions was reported by $\mathrm{Clark}$ and $\mathrm{Blanco}{ }^{(88)}$ Based on the literature search, they concluded that Corronel 230 is the most resistant material studied in 7 to $10 \mathrm{M} \mathrm{HNO}_{3}$ solutions having an uncomplexed fluoride concentration of about $0.05 \mathrm{M}$. The corrosion rate of $1.6 \mathrm{mils} /$ month found in $7 \mathrm{M} \mathrm{HNO}{ }_{3}-0.05 \mathrm{M} \mathrm{HF}$ was expected to increase slowly as the $\mathrm{HNO}_{3}$ concentration increases, and more rapidly as the concentration of free fluoride increases. The presence of low concentrations of dissolution products will decrease the rate of attack. Consequently, a maximum corrosion rate of $1.6 \mathrm{mil} / \mathrm{month}$ should be expected only during the initial dissolution period. They also reported that if the free fluoride concentration can be reduced to less than about 0.02M, Type $309 \mathrm{~S} \mathrm{Cb}$ stainless steel may be usable, al though Corronel would still be preferable. Weldments was found to have suffered the maximum attack for both alloys. 
The same authors also reported that Titanium is a possible candidate for use in 12 to $15 \mathrm{M} \mathrm{HNO}_{3}$ solutions that have free fluoride concentrations up to about $0.003 \mathrm{M}$. Results of corrosion tests were found encouraging for an aluminum dissolver in a solution of 22 to $23 \mathrm{M} \mathrm{HNO}_{3}$ and 1 to $2 \mathrm{M} \mathrm{HF}$.

Recently, a comprehensive review on the dissolution of High Temperature Gas-Cooled Reactors (HTGR) fuel has been conducted by Hutton. (89) Extensive and in depth review on corrosion of structural alloys used in the reprocessing of thoria-based fuels established the feasibility and desirability of (1) utilizing a batch Type 304L stainless steel dissolver and (2) boiling Thorex acid $\left[13 \mathrm{M} \mathrm{HNO}_{3} / 0.05 \mathrm{M} \mathrm{HF} / 0.1 \mathrm{M} \mathrm{Al}\left(\mathrm{NO}_{3}\right)_{3}\right]$ to dissolve HTGR fuel. Cursory tests of various other metals conducted by the Germans in the above solution indicate that the Ti/Pd alloy or titanium is the best material. However, much more extensive testing of the corrosion behavior of titanium is needed before it could be recommended for application to a Thorex system.

\subsubsection{Conclusion}

Based on the current available information on the fluoride induced cracking of stainless steels, it is obvious that this ion should be considered at least as dangerous as the chloride ion and the cleaning procedures for it should be as thorough as possible. However, this is apparently the only environment known to date to be particularly damaging to sensitized materials.

\subsection{Cracking of $\mathrm{Fe}-\mathrm{Cr}-\mathrm{Ni}$ Alloys in Caustic Environment}

Despite the technical importance and widespread occurrence of caustic stress corrosion cracking (CSCC), there is apparently less definition of the phenomenon than other types of stress corrosion cases, such as austenitic stainless steels in chloride environment. In general, not even the relative resistances of important alloys are known. Caustic is not as specific in its attack in that the whole range of alloys from mild steel to high nickel alloys will crack in caustic environments. The factors such as metallurgical structure effects, stress dependence, and the effects of temperature, hydroxide ion concentration, cation species, etc., have not been characterized. Most of the existing work on ironbase and nickel-base alloys has been summarized by Logan. ${ }^{(60)}$ He reported 
that carbon steels fail intergranularly by processes subject to undefined environmental inhibition processes, the austenitic steels can exhibit transgranular cracking, and higher nickel $\mathrm{Fe}-\mathrm{Ni}-\mathrm{Cr}$ alloys show intergranular cracking.

\subsubsection{The Effect of Stress}

The effect of stress on caustic stress corrosion cracking appears to be similar to that for chloride cracking shown in Figure 4.2-1. For an 18-9 Nb stainless steel (similar to Type 347 ), Snowdon ${ }^{(61)}$ shows that for $20 \% \mathrm{NaOH}$ at $300^{\circ} \mathrm{C}$, there is a stress below which cracking does not occur for extended times as shown in Table 4.4-1. The data for $20 \%$ $\mathrm{KOH}$ are similar, but the stress at which cracking will occur is much lower. Picket, et al ${ }^{(62)}$ show that a similar behavior exhibits for Type 304 stainless steel in $1 \% \mathrm{NaOH}$ at $349^{\circ} \mathrm{C}\left(650^{\circ} \mathrm{F}\right)$ as shown in Table 4.4-2. Funk and Barton ${ }^{(63)}$ reported that for Types 304 and 316 stainless steels, and Inconel 600 and 718 in a caustic environment, a trend to reduce the depth of cracking penetration as the stress is reduced from 100 to 33 percent of the $0.2 \%$ offset yield strength appears to exist as shown in Figure 4.4-1. However, it is significant to note that reduction of the stress to one-third of yield still does not eliminate the penetration depth of CSCC, at least under the condition of 20-day exposure to $50 \mathrm{~W} / \mathrm{O} \mathrm{NaOH}$ at $121^{\circ} \mathrm{C}$. Yakagan and Mikhailova ${ }^{(64)}$ also found that increasing stresses decreased the time to failure for a number of austenitic stainless steels. Wheeler and Howells ${ }^{(65)}$ found that threshold stress if any, is well below the yield strength for Type 347 stainless steel in caustic environment.

The data indicate that, as with chlorides, the threshold stresses for caustic induced stress corrosion cracking are so low that achieving such low levels in practice is impossible, or at best, impractical. Wanklyn and Jones conclude from their work that variations of stress are unlikely to influence the rate of attack greatly, though failure will be more rapid at higher stresses.

\subsubsection{The Effect of Caustic Concentration and Temperature}

Based on the failures reported in the Titerature, Swandby $(66)$ has produced the curve for caustic cracking shown in Figure 4.4-2 for 
TABLE $4.4-1$

EFFECTS OF CONCENTRATION, STRESS AND TEMPERATURE

WITH KOH AND NaOH SOLUTIONS ON THE CRACKING

OF 18-10 Nb STAINLESS STEELS ${ }^{(61)}$

Effect of Concn. at, $300^{\circ} \mathrm{C}$ and 10 tons $/$ in $^{2}$

\begin{tabular}{|c|c|c|}
\hline \multirow[b]{2}{*}{ Wt\% } & \multicolumn{2}{|c|}{ Life Hrs. } \\
\hline & $\mathrm{KOH}$ & $\mathrm{NaOH}$ \\
\hline 50 & 7.8 & 2.1 \\
\hline 20 & $3.8,19.8$ & $1.1, \quad 1.8$ \\
\hline 5 & $51.2,17.6$ & $6.4,15.1$ \\
\hline 1 & $17.9,150 *$ & - \\
\hline 0.1 & $551 *$ & - \\
\hline
\end{tabular}

$\star$

Unbroken
Effect of Temp. with

Effect of Stress at $300^{\circ} \mathrm{C}$

Stress
tons/in

$3.8,19.8 \quad 1.1,1.8$

137

$16.9,30.3 \quad 112,118$

$28.5,88.5 \quad 400 *$
10 tons $/$ In $^{2}$ Stress

\begin{tabular}{|c|c|c|c|}
\hline \multirow{2}{*}{$\begin{array}{c}\text { Temp } \\
{ }^{\circ} \mathrm{C} \\
\end{array}$} & \multicolumn{3}{|c|}{ Life Hrs. } \\
\hline & $20 \%$ & $\mathrm{KOH}$ & $20 \% \mathrm{NaOH}$ \\
\hline 300 & 3.8 , & 19.8 & $1.1,1.8$ \\
\hline 250 & 12.2 , & 55.7 & $3.6,1.6$ \\
\hline
\end{tabular}

$\begin{array}{llll}200 & 40.8, & 82.6 & 177.8\end{array}$

$175 \quad 43.7,195.8$

$150 \quad 500 *$ 
TABLE $4.4-2$

EFFECT OF APPLIED STRESS AND DEGREE OF COLD WORK

ON TIME TO INTERGRANULAR FAILURE OF TYPE 304

STAINLESS STEEL CAPSULES EXPOSED TO $10 \mathrm{gNaOH}$ PER

LITER AT $650^{\circ} \mathrm{F}\left(343^{\circ} \mathrm{C}\right)^{(62)}$

\begin{tabular}{|c|c|c|c|}
\hline $\begin{array}{c}\text { 0.2\% Yield Strength } \\
\text { (Room Temp.) } \\
\text { psi }\end{array}$ & $\begin{array}{l}\text { Applied Hoop } \\
\text { Stress } \\
\text { psi }\end{array}$ & $\begin{array}{l}\text { Number of } \\
\text { Capsules }\end{array}$ & $\begin{array}{c}\text { Exposure Time } \\
\text { During Which } \\
\text { Failure Occurred } \\
\text { Hours }\end{array}$ \\
\hline \multirow[t]{2}{*}{86,000} & 60,000 & 2 & $53-141$ \\
\hline & 17,000 & 2 & 2932 (no failure) \\
\hline \multirow[t]{2}{*}{50,000} & $\{58,000$ & 2 & $53-141$ \\
\hline & 17,000 & 2 & 2932 (no failure) \\
\hline
\end{tabular}

austenitic stainless steels. It is noted that only $\mathrm{NaOH}$ concentrations of between approximately 35\% to $65 \%$ will cause cracking in non-pressurized solutions. However, Wheeler and Howel1s ${ }^{(65)}$ found that Type 347 stainless steel cracked in $95 \% \mathrm{NaOH}$ solution at $650^{\circ} \mathrm{F}$, however, no cracking was observed above $750^{\circ} \mathrm{F}$ for a period of 30 days. No cracking was observed in $100 \% \mathrm{NaOH}$ at $650^{\circ} \mathrm{F}$ with stresses ranging from 17 to $26 \mathrm{ksi}$. Similar results were reported by Funk and Barton (63) for Types 304 and 316 stainless steels. It has been reported ${ }^{(67)}$ that the lower limit for cracking of Type 304 in ambient pressure boiling solution is $30 \%$ $\mathrm{NaOH}$. In pressurized solutions cracking has been observed at lower concentrations. Picket ${ }^{(62)}$ has reported that cracking of Type 304 stainless steel in $\mathrm{NaOH}$ solutions of 1 gram per liter at $349^{\circ} \mathrm{C}\left(650^{\circ} \mathrm{F}\right)$, is greatly accelerated at higher strength solutions. Table 4.4-1 shows the results of Snowdon ${ }^{(61)}$ for a $\mathrm{Nb}$ stabilized steel showing the effect of concentration of $\mathrm{KOH}$ and $\mathrm{NaOH}$ at $300^{\circ} \mathrm{C}\left(572^{\circ} \mathrm{F}\right)$. The table shows 


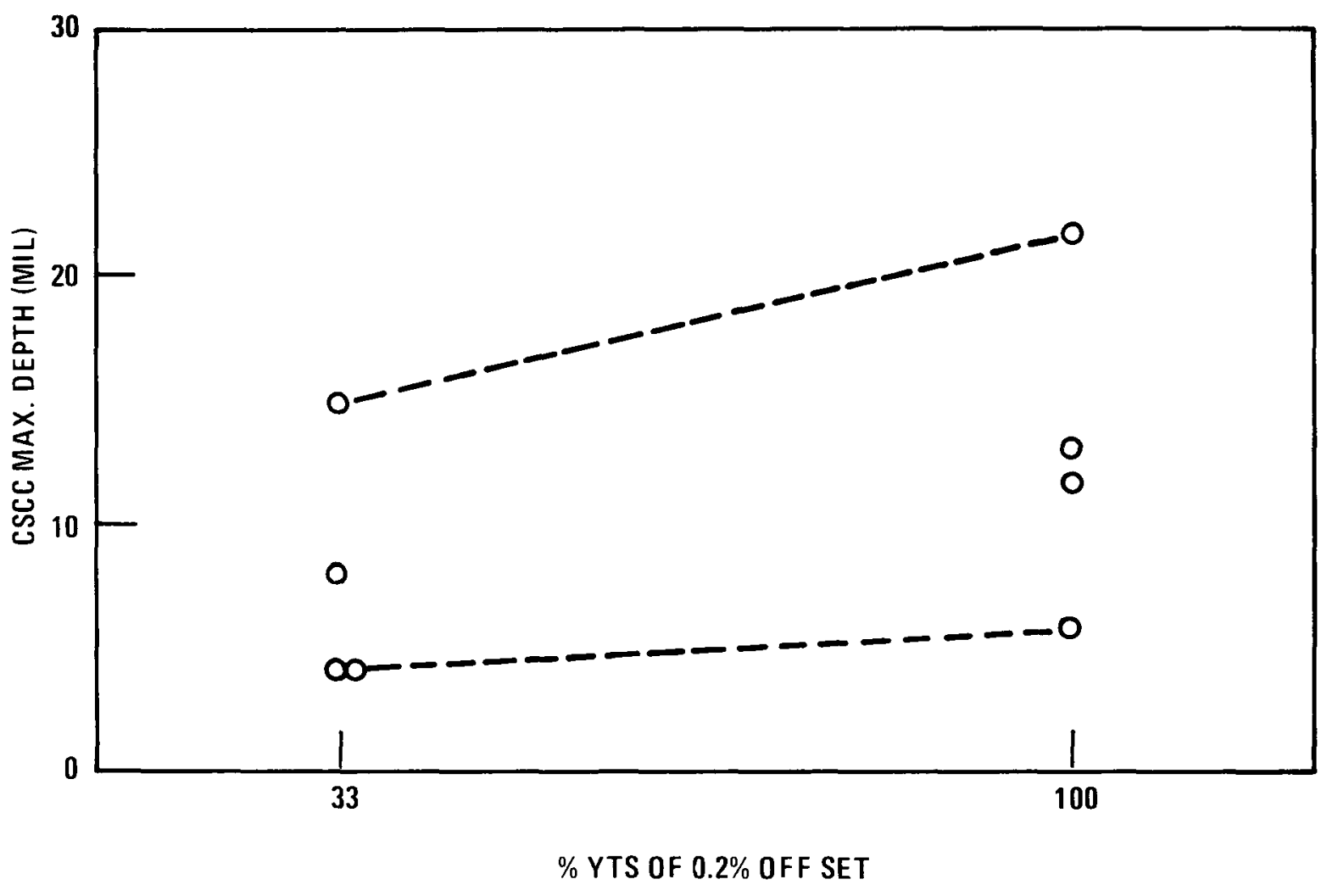

CONCLUSIONS:

1. RESULTS SHOW WIDE VARIANCES

2. DEPTH OF MAXIMUM CSCC DECREASES WITH STRESS

3. FIVE MIL MAXIMUM CRACK DEPTH WOULD REQUIRE YTS $<33 \%$

Figure 4.4-1. Effect of Stress State on Depth of Crack Penetration in $50 \mathrm{w}$ o $\mathrm{NaOH}$ at $250^{\circ} \mathrm{F}$ for 21 Days in 304 Type SS (Reference 64). 


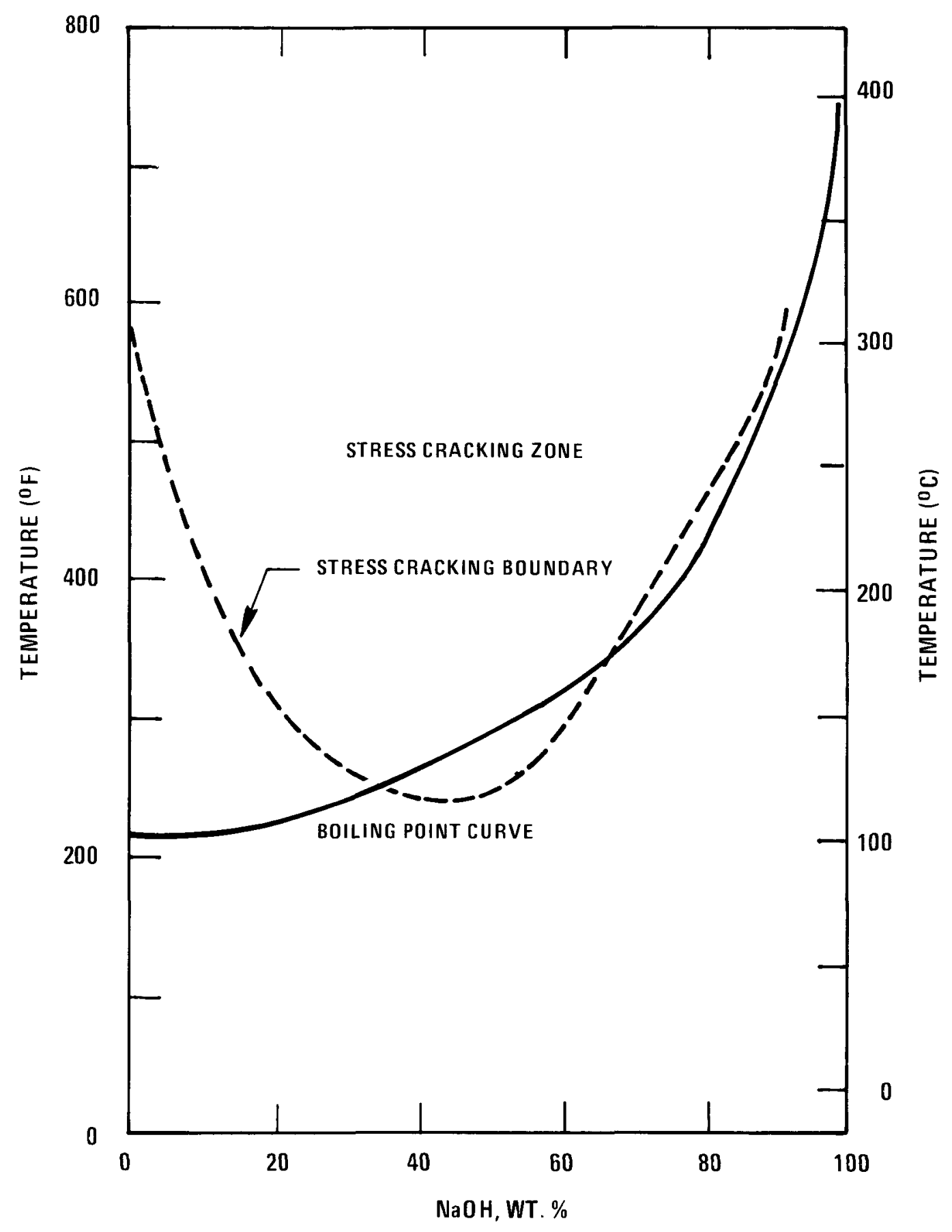

Figure 4.4-2. Temperature and Concentration of Sodium Hydroxide Necessary to Produce Stress Corrosion Craching in Types 304 and 316 Stainless Steels ( Reference 66). 
cracking in $1 \% \mathrm{KOH}$ but not by the low concentration reported by Picket, et al for $\mathrm{NaOH}$ solutions. This may be the result of the different cation but is more likely due to the lower temperature. Siderov and Ryabchenkov ${ }^{(68)}$ found that at about $43 \mathrm{ksi}$ load an 18-9 Ti stabilized steel failed in a $3 \% \mathrm{NaOH}$ solution at $210^{\circ} \mathrm{C}$ but at $330^{\circ} \mathrm{C}$ the same material failed in a $1 \% \mathrm{NaOH}$ solution. The same authors found that the time to failure versus absolute temperature followed an exponential relationship. Snowdon (59) observed cracking in $20 \% \mathrm{KOH}$ at $175^{\circ} \mathrm{C}$ but not at $150^{\circ} \mathrm{C}$ which is in good agreement with the curve of Figure 4.3-2. At high concentrations, Brush ${ }^{(69)}$ found that at $650^{\circ} \mathrm{F}$ Type 347 stainless steel cracked in 1 day in $80 \% \mathrm{NaOH}$ but did not crack within 30 days in $100 \% \mathrm{NaOH}$; their data are shown in Table 4.4-3. Wilson et al ${ }^{(70)}$ reported that increasing the caustic concentration from $10 \%$ to $50 \%$ changes the cracking mode of Types 304 and $304 \mathrm{~L}$ at $600^{\circ} \mathrm{F}$ from an intergranular to a transgranular mode as shown in Figure 4.4-3. The same authors also show that if the temperature of the $50 \%$ solution is reduced from $600^{\circ} \mathrm{F}$ to $300^{\circ} \mathrm{F}$ the cracking is still transgranular but the failure time is much longer. For Type 316 and $316 \mathrm{~L}$ stainless steels, transgranular crack was observed in $50 \% \mathrm{NaOH}$ at 149,316 , and $371^{\circ} \mathrm{C}$, and heat treatment had no effect on the time to failure.

Pement ${ }^{(71)}$ found that increasing the temperature or the concentration of $\mathrm{LiOH}$ solutions increased the probability of failure of cold worked Type 347 stainless steel. However Wilson et al ${ }^{(70)}$ reported that cold work did not affect the time or the mode of cracking of Types 304 and 316 stainless steels. The effects on crack morphology of conducting tests in superheated steam ${ }^{(61)}$ can be attributed to concentrating of the caustic in superheated regions. The fact that caustic solutions have low vapor pressures means that a liquid phase of concentrated caustic solutions can be present at very high temperatures and low pressures. As in the chloride environment, oxygen appears also to play an important role on the cracking of austenitic stainless steels in caustics. 
TABLE $4.4-3$

STRESS CORROSION CRACKING OF TYPE 347 STAINLESS

STEEL U-BENDS EXPOSED TO NaOH SOLUTIONS ${ }^{(69)}$

\begin{tabular}{cccc}
$\begin{array}{c}\text { Concentration } \\
\%\end{array}$ & $\begin{array}{c}\text { Temp } \\
{ }_{0}^{\circ} \mathrm{F}\end{array}$ & $\begin{array}{c}\text { Time } \\
\text { Days }\end{array}$ & Cracks \\
\hline 100 & 650 & 30 & No \\
& 750 & 30 & No \\
& 850 & 30 & Yes \\
80 & 650 & 1 & Yes \\
95 & 750 & 30 & No \\
96 & 850 & 30 & No \\
$.2 \mathrm{~mol} \mathrm{NaOH} / \mathrm{mol} \mathrm{Na}$ & 850 & 30 & Yes \\
$.5 \mathrm{~mol} \mathrm{NaOH} / \mathrm{mol} \mathrm{Na}$ & 850 & 30 & Yes \\
$1 \mathrm{~mol} \mathrm{NaOH} / \mathrm{mol} \mathrm{Na}$ & 850 & 30 & Yes
\end{tabular}

Copson ${ }^{(1)}$ reported that high overpressures of air induced cracking in Inconel $600 \mathrm{U}$-bends in $90 \% \mathrm{NaOH}$ at $300^{\circ} \mathrm{C}\left(572^{\circ} \mathrm{F}\right)$ as shown in Table 4.4-4. Type 304 stainless steel appears to be most susceptible at lower air overpressures. However, it was concluded ${ }^{(1)}$ that air is not necessary for the caustic cracking of austenitic steels as it is for chloride induced cracking.

It was reported $(72)$ that sodium hydroxide $(\mathrm{NaOH})$ in liquid sodium will cause cracking in Type 347 U-bends as shown in Table 4.4-3. However no cracking was observed in bent or welded and bent specimens of stabilized 2-1/4 $\mathrm{Cr}-1$ Mo and Type 316 stainless steel in liquid sodium contaminated with sodium hydroxide at 400,500 , and $600^{\circ} \mathrm{C} .(73)$ 


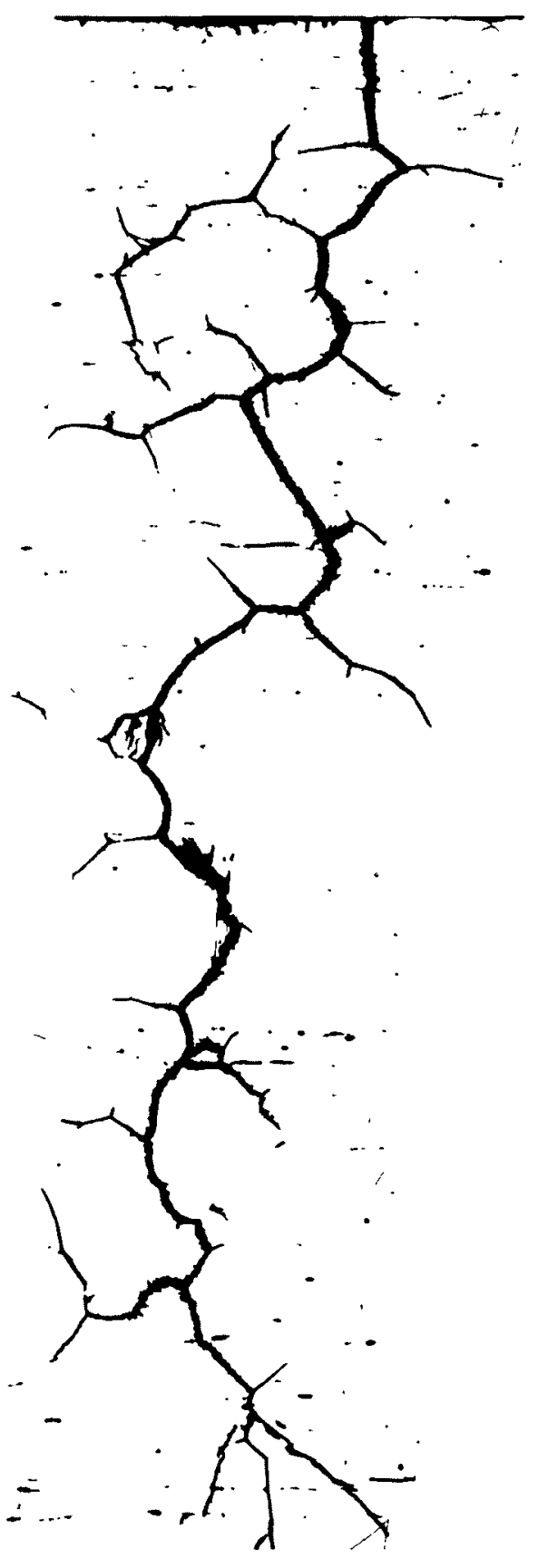

a)

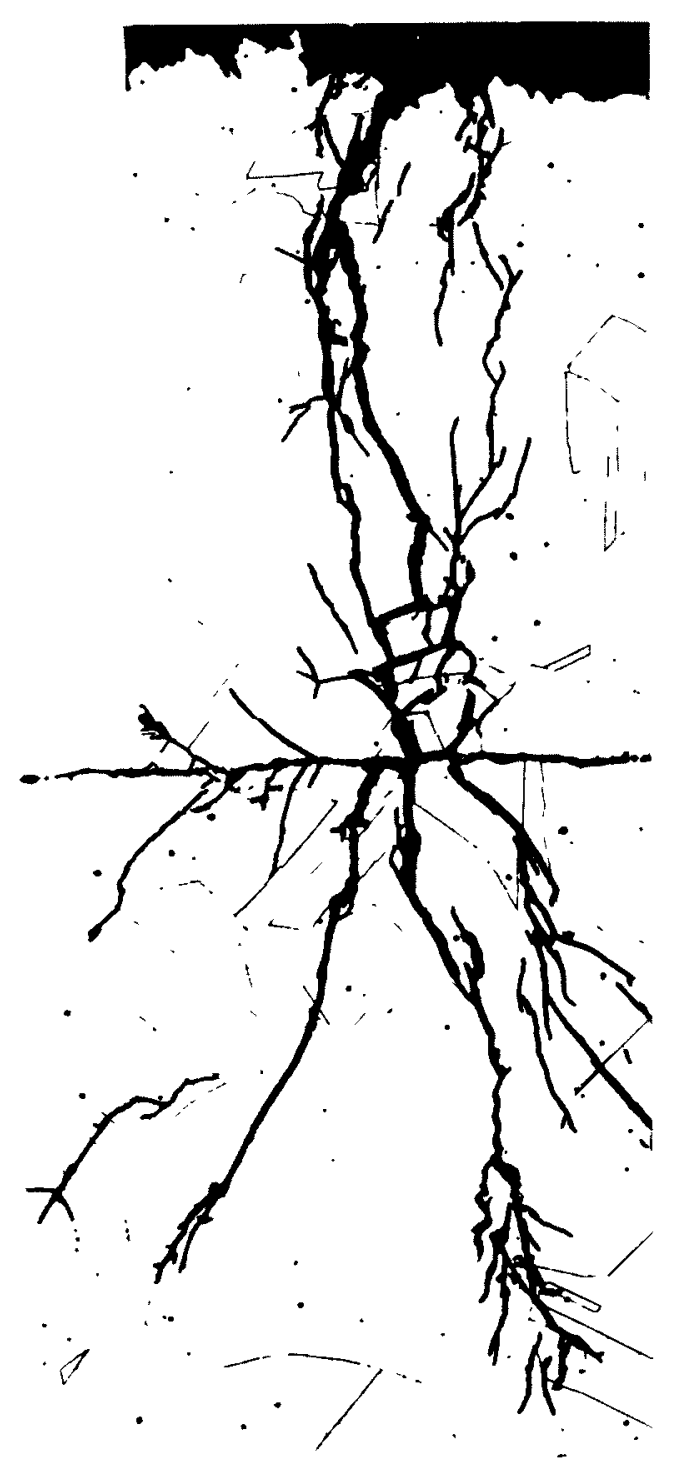

b)

Figure 4.4-3 Stress Corrosion Cracks in Type 304 Stainless Steel $U$-Bends After Exposure at $600^{\circ} \mathrm{F}$ Showing

(a) Intergranular Cracking in De-Aerated $10 \% \mathrm{NaOH}$

(b) Transgranular Cracking in De-Aerated $50 \% \mathrm{NaUH}$ Mag. 200x (Reference 70). 


\subsubsection{The Effect of Alloy Content}

The dependence of caustic stress-corrosion cracking on alloy content is not the same for austenitic stainless steels as it is in the chloride environment. This is illustrated by the work of Swandby $(74)$ and Berk and Waldeck ${ }^{(75)}$ who found a similar effect of caustic concentration and temperature on the cracking of mild steel and Types 304 and 316 stainless steels. Stabilized 2-1/4 $\mathrm{Cr}-1$ Mo steel has not been observed to crack in caustic contaminated environments $(73,76)$ but high corrosion rates are observed. However, welds in stressed, stabilized 2-1/4 Cr-1 Mo steel have been observed to crack after contamination with liquid sodium and exposure to a moist environment. (76)

The $12 \% \mathrm{cr}$ steels of the 410 type crack in caustic solutions. The temperature dependence of the cracking is probably similar to that shown for chloride cracking but without the immunity at low and high tempering temperatures. Using a $12 \% \mathrm{Cr}$ steel tempered at $482^{\circ} \mathrm{C}$, Durkin $(77)$ produced cracking in $10 \% \mathrm{NaOH}$ within comparatively short time, as shown in Figure 4.4-4. Cracks were also observed in materials used for turbine blades $\left(12 \% \mathrm{Cr}\right.$ martensitic steel temperated at approximately $\left.640^{\circ} \mathrm{C}\right)$ at a stress of $33 \mathrm{ksi}$ in $28 \% \mathrm{NaOH}$ at $66^{\circ} \mathrm{C} .{ }^{(78)}$ After testing a large range of alloys in caustic solutions, Snowdon ${ }^{(79)}$ concluded, see Table 4.4-5, that martensitic and ferritic stainless steels may not suffer rapid stress corrosion cracking in caustics but general attack can occur under severe conditions. In addition, he reported that dependence of cracking on alloy content is inconsistent in caustic solutions. However, higher nickel alloys can show some superiority and the presence of $\delta$ ferrite in a Ti stabilized 18-8 stainless steel may be beneficial. The beneficial effect of higher nickel content was also reported by many other investigators. ${ }^{74,30)}$ Coriou, et al ${ }^{(81)}$ found that for lower nickel alloys, the failure has been transgranular but for higher nickel alloys, the cracking has been predominantly intergranular. However, the difference in other alloying elements in the various Inconels shown in Table 4.4-6 may have also affected the failure mode. The results of Truman and 
TABLE $4.4-4$

THE EFFECT OF DEGREE OF AERATION ON THE CAUSTIC CRACKING OF INCONEL 600 AND TYPE 304 STAINLESS STEEL U-BENDS AT $300^{\circ} \mathrm{C}\left(572^{\circ} \mathrm{F}\right)$ IN $90 \% \mathrm{NaOH}(1)$

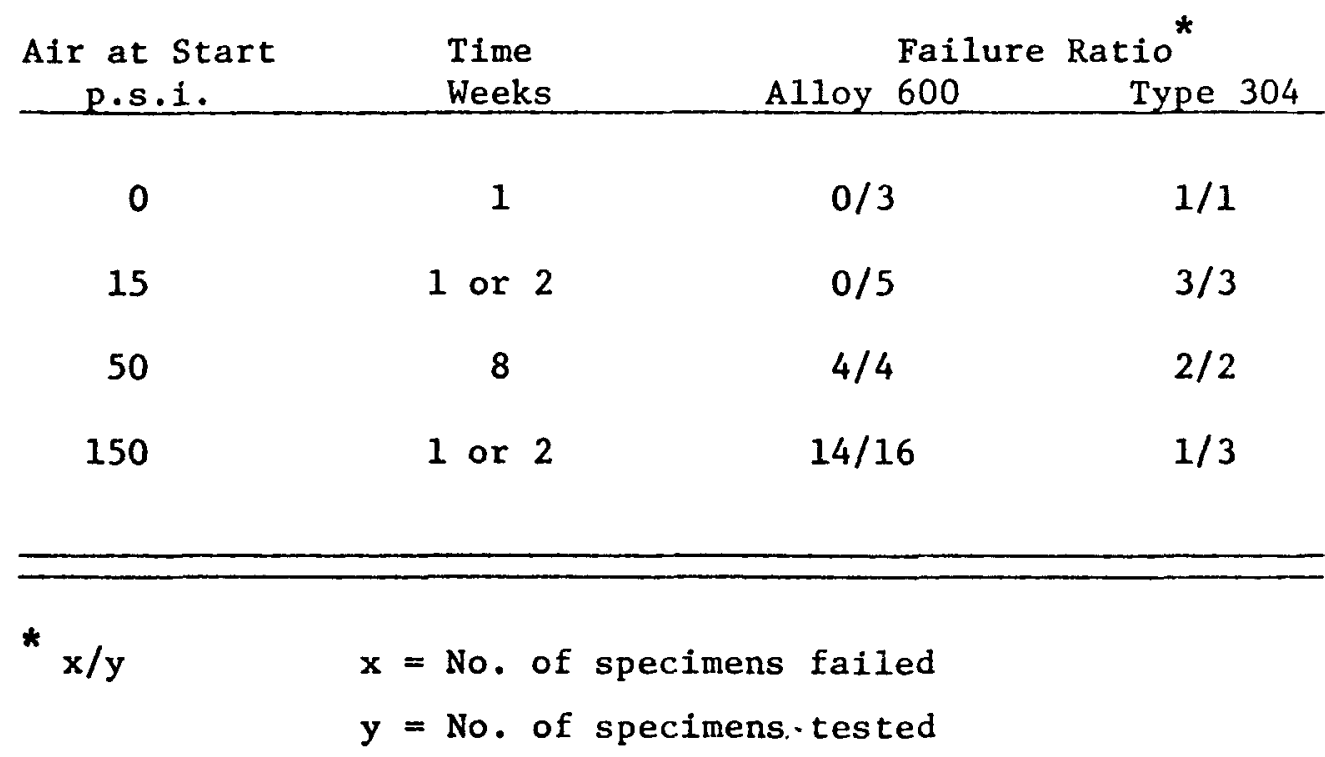

Perry $(53)$ also indicate that increasing nickel content is beneficial in $10 \%$ and $15 \% \mathrm{Cr}$ alloys but that increasing the nickel content is detrimental in $20 \%$ and $25 \% \mathrm{Cr}$ alloys as shown in Figure 4.4-5. High nickel in $15 \%$ $\mathrm{Cr}$ alloys, such as Inconel 600 , are not immune to caustic induced stress corrosion cracking as shown in Table 4.4-6. Furthermore, it was shown that the presence of oxygen appears to affect the alloy dependence of caustic induced stress corrosion cracking.

Carbon appears to have little or no effect on the caustic cracking of austenitic stainless steels. $(61,70,82)$ Snowdon $(61)$ has reported that stainless steels with $0.03 \% \mathrm{C}$ fail transgranularly and those with 0.07 to $0.11 \% \mathrm{C}$ fail intergranularly. However, these results were not corroborated by Wilson et al. (70) 
TABLE $4.4-5$

BEHAVIOR OF VARIOUS Fe-Cr-Ni ALLOYS IN CAUSTIC

ALKALI ENVIRONMENTS (53)

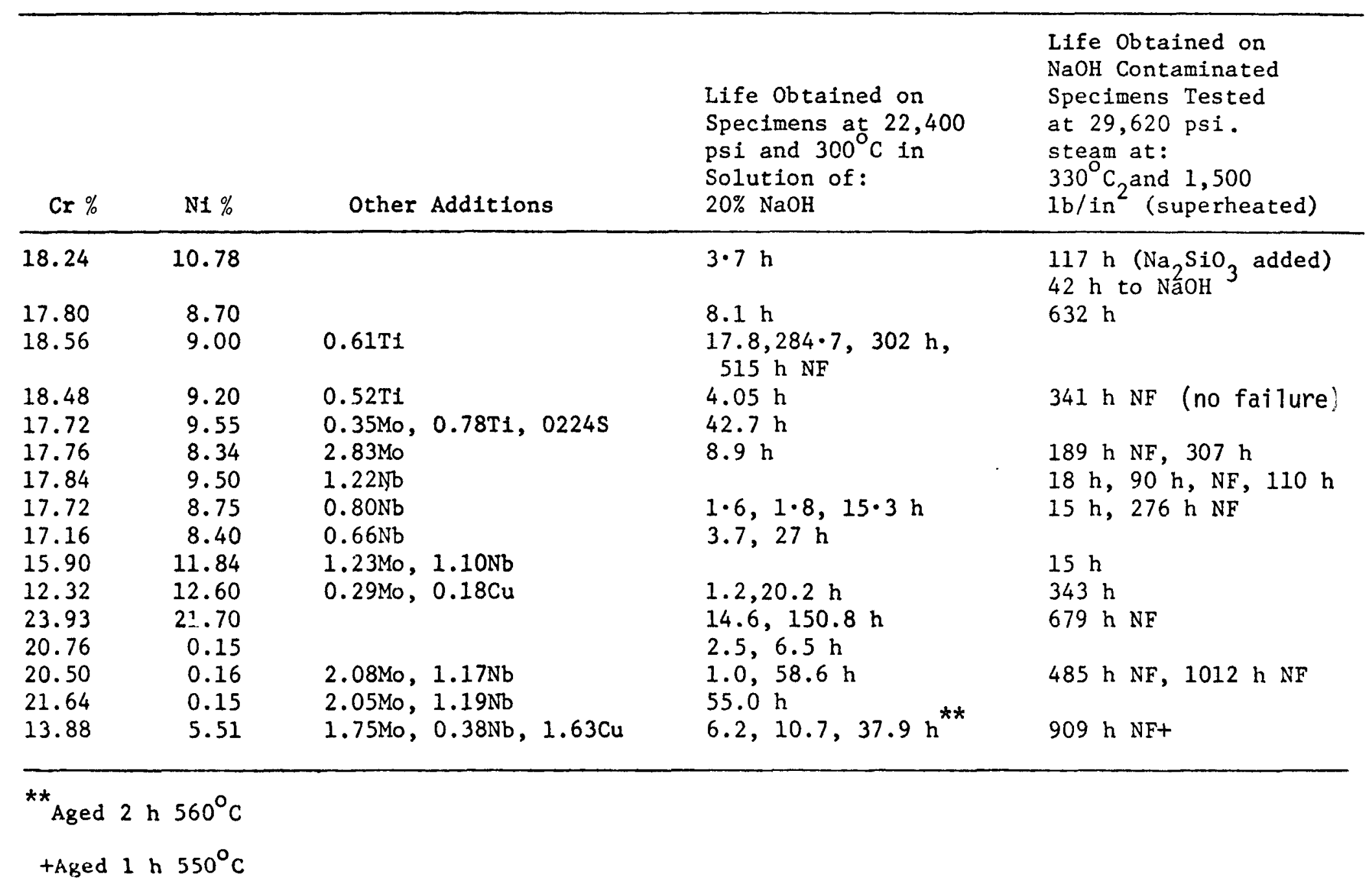




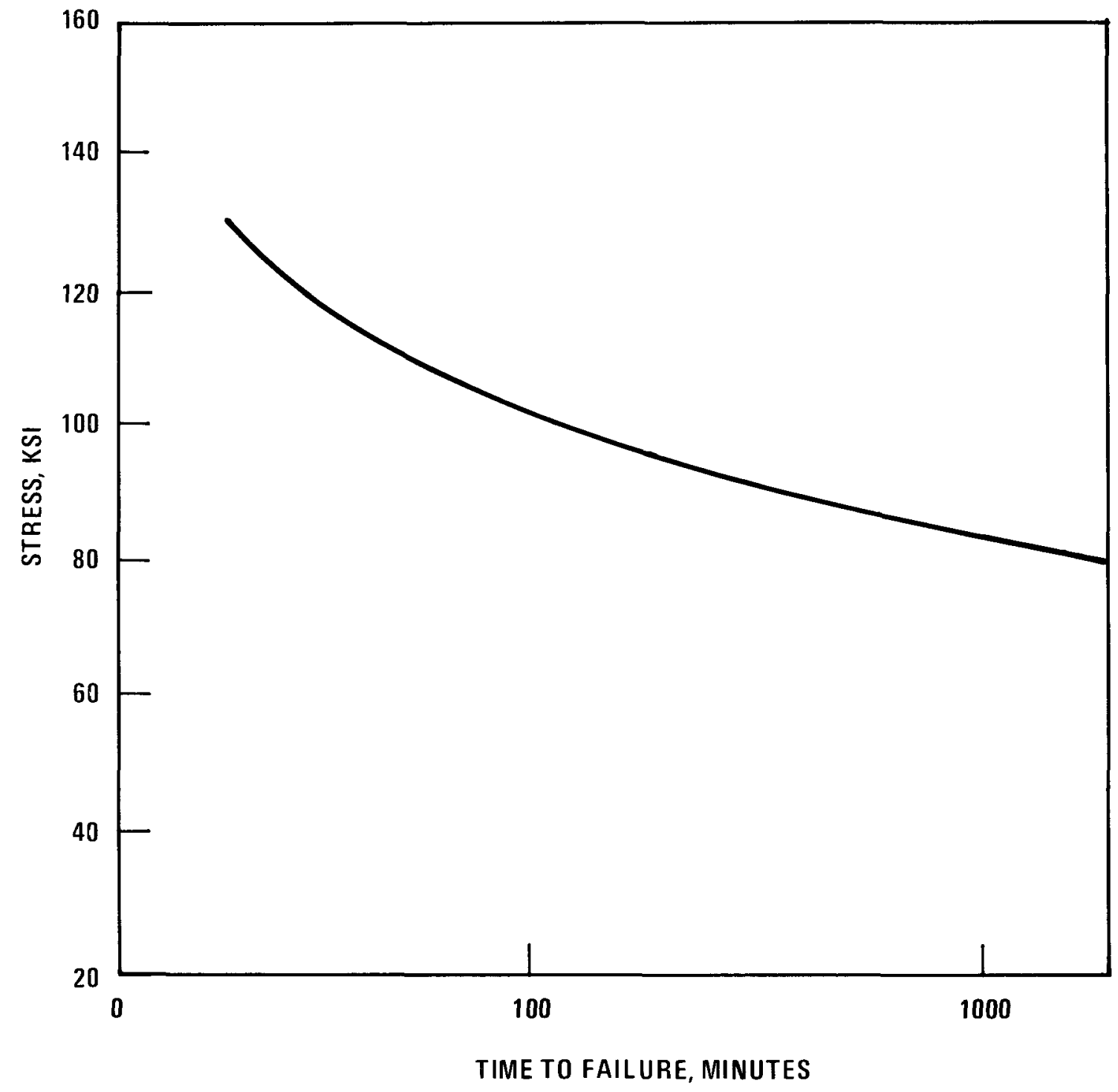

Figure 4.4-4 Time-to-Failure Versus Bending Stress tor a 12', Cr Steel in 10', NaOH Solution (Reference 77). 


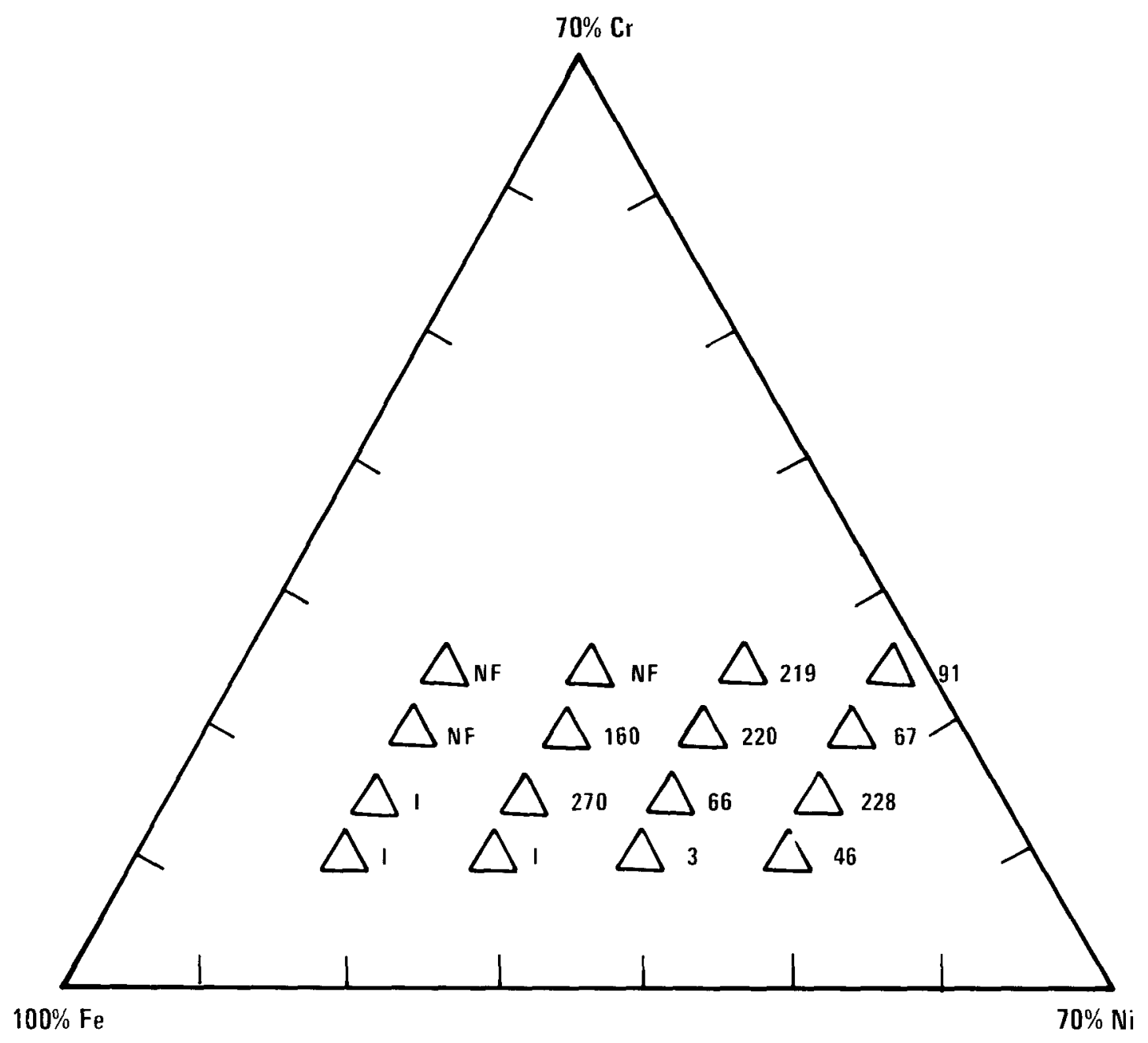

Figure 4.4-5. Time-to-Failure in Hour for Alloys as Shown Above in 50', $\mathrm{NaOH}$ at $300 \mathrm{C} 2000$ PSI $\mathrm{O}_{2}$ and Stressed to 22.400 PSI. NF $=$ Not Failed in $500 \mathrm{~h}$ (Reference 53 ). 
TABLE 4.4-6

STRESS CORROSION CRACKING TESTS ${ }^{\mathrm{a}}$ IN ALKALINE ENVIRONMENTS ${ }^{(53)}$

\begin{tabular}{|c|c|c|c|c|}
\hline \multirow[b]{2}{*}{ Material } & \multicolumn{2}{|c|}{$\begin{array}{l}\text { Solution Pressurized } \\
\text { with } 150 \text { psi Air }\end{array}$} & \multicolumn{2}{|c|}{$\begin{array}{l}\text { Solution Pressurized } \\
\text { with } 150 \text { psi Argon }\end{array}$} \\
\hline & $\begin{array}{l}\text { Path of } \\
\text { Cracking }\end{array}$ & $\begin{array}{l}\text { Depth of } \\
\text { Cracking }\end{array}$ & $\begin{array}{l}\text { Path of } \\
\text { Cracking }\end{array}$ & $\begin{array}{l}\text { Depth of } \\
\text { Cracking }\end{array}$ \\
\hline MONEL A1loy 400 & Intergranular & Deep & -- & -- \\
\hline INCONEL AIlOY 600 & Intergranular & Deep & None & $\mathrm{Nil}$ \\
\hline INCONEL A11oy 625 & Transgranular & Deep & None & Nil \\
\hline INCOLOY Alloy 800 & None & $\mathrm{Nil}$ & Transgranular & Shallow \\
\hline INCOLOY A11oy 825 & Mixed & Shallow & -- & -- \\
\hline Hastelloy Alloy C & Mixed & Deep & -- & - \\
\hline Type 304 Stainless & Transgranular & Shallow & Transgranular & Deep \\
\hline
\end{tabular}

The effect of molybdenum on the caustic cracking of austenitic steels has been contradictory. Snowdon ${ }^{(79)}$ has shown that an $18-8,2.8$ Mo steel has a slightly longer life than an 18-10 steel in various caustic solutions, and Staehle ${ }^{(82)}$ has reported a greater life for Type 316 than Type 304 in a boiling $50 \% \mathrm{NaOH}$ solution. However, the differences are marginal and in the latter case it may be due to general corrosion resistance and not the stress corrosion resistance. Coriou ${ }^{(81)}$ tested a range of alloys, shown in Table $4.4-7$, in $2.5 \mathrm{~N} \mathrm{NaOH}$ at $360^{\circ} \mathrm{C}$ and observed cracking in all after 1 month exposure. However, a higher percentage of cracked specimens was observed with the molybdenum containing alloys. In the same work, silicon content was found to have little effect on the susceptibility of these alloys to caustic cracking. Wilson et a ${ }^{(70)}$ found that Type 316 
U-bends will crack in boiling $50 \% \mathrm{NaOH}$ but did not observe cracking with Type $304 \mathrm{U}$-bends as shown in Table 4.4-8.

Titanium appears to be a better stabilizing addition than niobium for caustic cracking resistance. Kagan and Mikhailova ${ }^{(64)}$ and Snowdon (79) show that a $T i$ containing austenitic steel is less susceptible to cracking than Mo or Nb containing steels. As shown in Table 4.4-9, Staehle ${ }^{(82)}$ and Powers and Tymchyn ${ }^{(83)}$ have shown that Type 347 is more susceptible than Type 304 stainless steel to caustic cracking.

\subsubsection{The Effect of Alloy Structure}

Picket, et al ${ }^{(62)}$ reported that cold work had no effect on the intergranular cracking of Type 304 exposed to solution of 10 gram NaOH per liter at $324^{\circ} \mathrm{C}$ as shown in Table 4.4-2. Wilson, et al ${ }^{(70)}$ have found that some "sensitizing" treatments at $640^{\circ} \mathrm{C}$ for 10 hours prevented intergranular cracking of mill annealed Type 304, but had no effect on the larger grained solution annealed material as shown in Table 4.4-10.

TABLE $4.4-7$

CHEMICAL COMPOSITIONS OF VARIOUS STAINLESS

STEELS STUDIED BY CORIOU ${ }^{(81)}$

$\begin{array}{lccccccc}\text { Designation } & \underline{\mathrm{C}} & \underline{\mathrm{Cr}} & \underline{\mathrm{Ni}} \cdot \underline{\text { Mo }} & \underline{\text { Si }} & \underline{\text { Mn }} & \begin{array}{c}\text { Other } \\ \text { Elements }\end{array} \\ 17 / 13 \text { Mo Cu } & 0.018 & 17.6 & 13.0 & 2.5 & 0.4 & 0.8 & \text { Cu } 1.66 \\ 17 / 13 \mathrm{Mo} & 0.024 & 17.6 & 13.4 & 2.8 & 0.6 & 1.6 & \\ 18 / 14 \mathrm{Si} & 0.027 & 17.7 & 14.4 & 0.7 & 3.9 & 0.7 & \\ 17 / 10 & 0.017 & 17.5 & 10.5 & & 0.3 & 1.0 & \\ 17 / 15 & 0.025 & 17.2 & 14.9 & & 0.5 & 1.0 & \\ 17 / 25 & 0.016 & 17.1 & 24.5 & & 0.5 & 1.0 & \\ 17 / 35 & 0.025 & 17.3 & 34.7 & & 0.5 & 1.1 & \\ 17 / 45 & 0.014 & 17.3 & 44.3 & & 0.5 & 1.1 & \\ 17 / 65 & 0.008 & 17.5 & 64.5 & & 0.5 & 1.1 & \\ 17 / 77 & 0.026 & 17.8 & 77.5 & & 0.5 & 1.1 & \\ 15 / 78 & 0.040 & 14.0 & 78.4 & & 0.2 & 0.1 & \text { Ti } 0.2 \\ \text { (Incone1 600) } & & & & & & & \end{array}$


TABLE 4.4-8

CRACKING IN $50 \% \mathrm{NaOH} @ \approx 300^{\circ} \mathrm{F}$ AND STRAUSS TEST RESULTS $(70)$

\begin{tabular}{|c|c|c|c|c|}
\hline Material & Heat Treatment and Hardness & $\begin{array}{c}\text { Exposure Period } \\
\text { at Failure } \\
\end{array}$ & Cracking & Strauss Test \\
\hline 1. $304 \mathrm{SS}$ & As rec. & 2000 hrs N.F. & -- & Pass \\
\hline 2. $304 \mathrm{SS}$ & As rec. $+1200^{\circ} \mathrm{F} / 10 \mathrm{hrs}$ & 1090 hrs N.F. & -- & Fail \\
\hline 3. $304 \mathrm{SS}$ & $2300^{\circ} \mathrm{F} / 1 \mathrm{l} / 2 \mathrm{hrs} /$ fast cool & $1 / 4 *<750 \mathrm{hrs}$ & Trans. & Pass \\
\hline 4. $304 \mathrm{SS}$ & As $3+1200^{\circ} \mathrm{F} / 10 \mathrm{hrs}$ & 1000 hrs N.F. & -- & Fail \\
\hline 5. $304 \mathrm{~L}$ SS & As rec. & 2000 hrs N.F. & -- & Pass \\
\hline 6. $304 \mathrm{~L} \mathrm{SS}$ & As rec. $+1200^{\circ} \mathrm{F} / 10 \mathrm{hrs}$ & 1090 hrs N.F. & -- & Pass \\
\hline 7. $316 \mathrm{ss}$ & As rec. & $900 \rightarrow 1100 \mathrm{hrs}$ & Trans. & Pass \\
\hline 8. $316 \mathrm{~L} \mathrm{SS}$ & As rec. & $1 / 2^{\dagger} 700 \rightarrow 900 \mathrm{hrs}$ & Trans. & Pass \\
\hline
\end{tabular}

* 1 of 4 failed others showed many small penetrations.

+1 of 2 failed 
TABLE 4.4-9

CAUSTIC CRACKING OF WELDED INCONEL AND STAINLESS STEEL CAPSULE SPECIMENS EXPOSED AT $636^{\circ} \mathrm{F}(64,79)$

\begin{tabular}{llcc} 
Environment & Alloy & $\begin{array}{c}\text { Number } \\
\text { of Specimens }\end{array}$ & $\begin{array}{c}\text { Individual Specimen } \\
\text { Cracking Times } \\
\text { (Days) }\end{array}$ \\
\hline \multirow{3}{*}{$1 \mathrm{M} \mathrm{NaOH}$} & Inconel $^{\mathrm{a}}$ & 6 & $45^{*}, 70,80,145,165,>165$ \\
& 304 Stainless & 6 & $<1,2,3,3,3,5$ \\
& 347 Stainless & 6 & $<1,<1,<1,<1,3,5$
\end{tabular}

(a) Welded with INCO 62 wire.

(b) All specimens except (*) failed in the weld metal or weld heataffected zone.

A simulated stress relief anneal of $899^{\circ} \mathrm{C}\left(1650^{\circ} \mathrm{F}\right)$ for 2 hours followed by a furnace cool was given, before stressing, to Type 304 with two different grain sizes and to $20 \%$ cold rolled material. This treatment sensitized all of the materials but prevented intergranular failure in $10 \% \mathrm{NaOH}$ at $316^{\circ} \mathrm{C}\left(600^{\circ} \mathrm{F}\right)$. However, the same approach did not prevent failure of Types $304 \mathrm{~L}, 316$, and $316 \mathrm{~L}$ stainless steels.

\subsubsection{Caustic Stress Corrosion Cracking Associated with Sodium}

Since sodium is used as the coolant in the LMFBRs, maintenance and examination of the LMFBR steam generators require removal of sodium from components of the system. One process for removal involves reacting sodium with water vapor and subsequent rinsing with water to remove residual $\mathrm{NaOH}$ on the components. This process exposes components such as pumps, valves, heat exchangers, and fuel handling machines to contact 
STRESS CORROSION CRACKING IN $10 \% \mathrm{NaOH}$ AT $600^{\circ} \mathrm{F}$, AND STRAUSS TEST RESULTS $(70)$

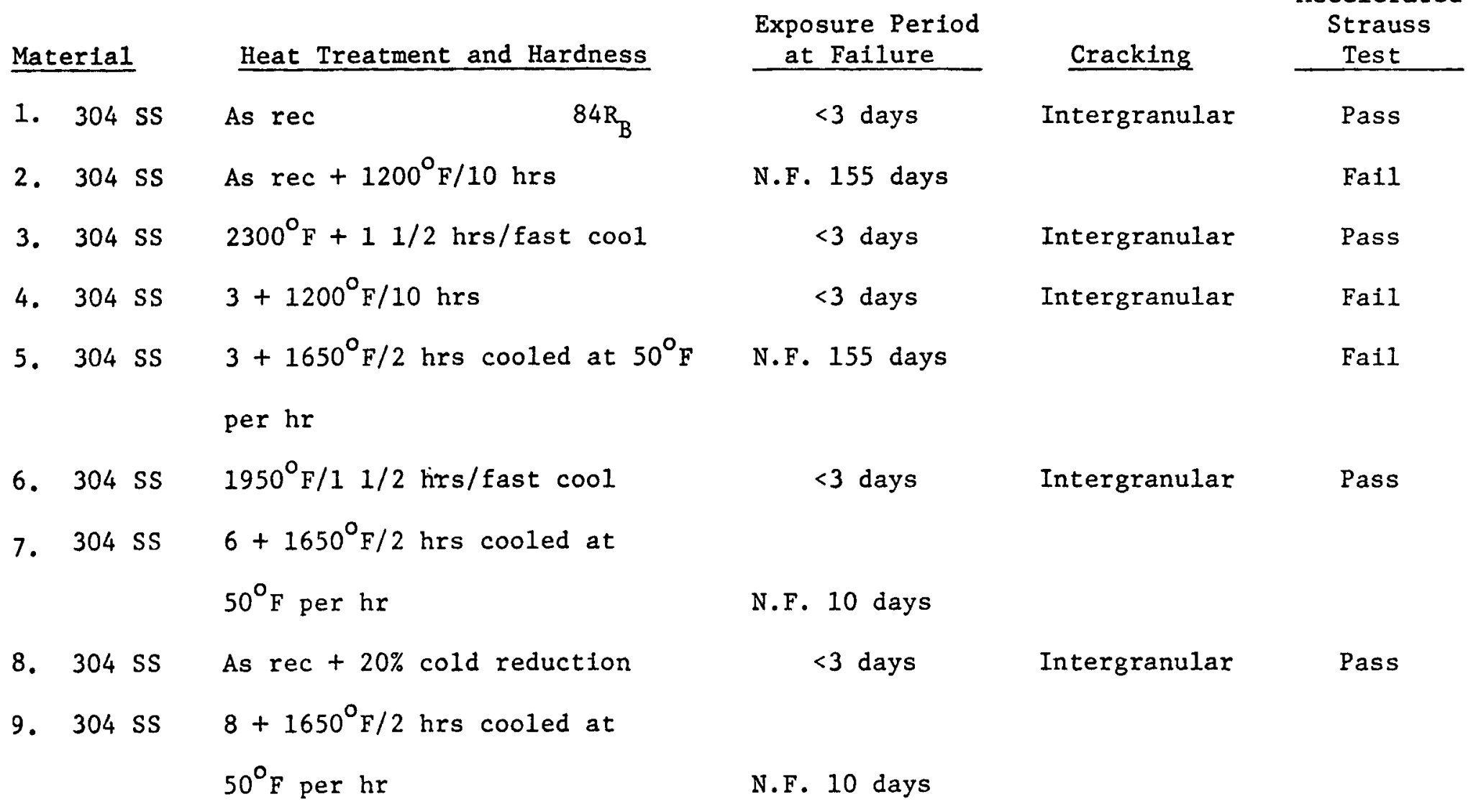


with aqueous $\mathrm{NaOH}$ solutions in various concentrations over a range of temperatures and times. Since stress may be present in these components, as generated during fabrication, structural loads, heat treating, welding, deformation in service, and possible wedging action by corrosion products, conditions are potentially available for caustic stress corrosion cracking. The main structural alloys for LMFBR components are Types 304 and 316 stainless steels which are susceptible to CSCC. Therefore, investigations are being conducted at HEDL ${ }^{(63)}$ to establish the threshold stress of CSCC so that the components can be processed under conditions avoiding CSCC. Early case histories of CSCC related to the removal of sodium from nuclear components are summarized by Funk and Barton (63) as shown in Table 4.4-11, along with the conditions of the exposure as reported in the literature. (90) In each case, either the temperature, time, or stress level was reported to be high; that is, beyond what is considered good practice to avoid CSCC.

\subsubsection{Conclusion}

Caustic induced stress corrosion cracking of the 300 series stainless steels occurs in general in $\sim 35$ to $65 \% \mathrm{NaOH}$ solutions. However, the higher concentrations may still cause cracking, particularly if air and/or moisture is present. At high temperatures, excessive caustic corrosion may also be significant. In an oxygen free system and in $\mathrm{NaOH} / \mathrm{Na}$ mixtures it appears that the higher nickel commercial alloys are better, especially if the chromium content is in the region of $15 \%$. The nickel free ferritic and martensitic alloys will crack in caustics and also corrode rapidly. Although molybdenum containing alloys may have a better corrosion resistance in caustic solutions, their stress corrosion resistance appears to be worse. In addition, the stabilized grade Types 321 and 347 stainless steels with $\mathrm{Ti}$ and/or Nb additions are also susceptible to caustic stress corrosion cracking (CSCC). 
TABLE $4.4-11$

CASE HISTORIES OF CAUSTIC STRESS CORROSION CRACKING ASSOCIATED WITH SODIUM

EXAMPLE

SEAWOLF

Superheater

(GE)

PHENIX reactor charging machine bolts (French)

Reactor pump bolts (French)

Piping of pump bearing test facility (Liquid Metal Engineering

Center)

Bolts equivalent to FFTF In-Vessel Handling Machine (Atomics Internationa? and Hanford Engineering Development Laboratory)
EXPOSURE CONDITIONS

OBSERVATIONS

REFERENCES

High-temperature, superheated steam

Severe cracking

Steam cleaned 4 times, not

disassembled, exposed 2

months in water, overstressed

in last sodium exposure

Steam cleaned, not disassembled

200 to $700^{\circ} \mathrm{F}, 2$ to 10 days, Type 304SS, $2 \times 6 \times 0.28$-inch pipe, unrelieved welds

325 to $400^{\circ} \mathrm{F}$ in $50 \mathrm{w} / 0 \mathrm{NaOH}$, 304 Type SS, 0.5-inch dia bolts
3 bolts ruptured, 20 bolts cracked under head or in first thread
Transgranular cracking with branching in weld head-affected zone

Gross cracking $50 \%$ of HEDL diameter 
Carbon has not been shown to have a significant effect on CSCC. Likewise, cold work does not appear to be deleterious but if the residual stresses are tensile they may be sufficient to produce cracking. The level of stress at which caustic cracking can occur appears to be sufficiently low to make the achievement of such a level impractical from the engineering standpoint.

\subsection{Overall Conclusion}

The problem of stress corrosion cracking is one of the most serious problems in development of reliable equipment in power and chemical industries. However, due to economic and mechanical integrity considerations there is very little room in compositional modification to improve or prevent stress corrosion cracking. In general, the higher nickel containing alloys are more resistant to cracking in chloride and hydroxide environment. Molybdenum appears to be deleterious to cracking resistance in chlorides and caustics. In commercial steels the increased nickel content of Type 316 over Type 304 appears to compensate for the bad effect of molybdenum on chloride cracking but not on caustic cracking.

Among the stabilized stainless steels, niobium stabilized Type 347 stainless steel appears to be more resistant to SCC than the titanium stabilized Type 321 stainless steel in a chloride environment. However, for caustic cracking the trend is reversed in that the titanium becomes a less deleterious addition than niobium. Based on the information available to date, almost all commercial alloys are susceptible to stress corrosion cracking and the most likely contaminants are chlorides or hydroxides. Consequently, the choice of a material in terms of stress corrosion cracking will not be of an immune alloy over a susceptible one, but of an alloy which shows a considerably longer incubation period before initiation of stress corrosion cracking.

The recognition of the potential for stress corrosion cracking has necessitated that in the nuclear industry extreme precautions are necessary to minimize the likelihood of occurrence of such failures. 


\subsection{EFFECT OF RADIATION ON THE CORROSION OF STAINLESS STEEL IN}

AQUEOUS SOLUTION

Radiation from isotopic sources is an important power factor, and it should be taken into account in all nuclear design applications. The radiation changes the properties of all substances, especially the cladding material of the nuclear fuel elements. Because the interaction of radiation with the metals and corrosive media changes the potentials of the metals or alloys, therefore, corrosion processes are always affected by radiation. However, the quantitative effects of radiation on corrosion phenomena have not been adequately addressed.

In the early investigations, the effect of radiation was grossly overestimated, and it was expected to have a significant influence. It was found later that in a number of cases radiation had a negligible effect on corrosion phenomena, and it was then assumed that the radiation effects are so small that they may be neglected. However, due to the development of modern nuclear technology, more extensive investigations have been conducted and the results show that there are cases in which the radiation causes a marked increase in the corrosion rate of metals and alloys.

Corrosion problems are of much greater importance in nuclear technology than in other branches of industry. The development of a new generation and sophisticated nuclear reactors imposes severe demands on materials of construction. Such is the case with the advent of the Liquid Metal Fast Breeder Reactor (LMFBR) where high operating temperatures and high neutron fluxes can cause rapid degradation of materials properties such as ductility.

Despite their relatively large thermal-neutron captüre cross sections, austenitic stainless steels of the $18 \% \mathrm{Cr}-8 \% \mathrm{Ni}$ type are widely used in the manufacture of various reactor components, and even as fuel-element cladding for the sodium-cooled fast breeder reactors. The main advantage of the austenitic stainless steels is their high corrosion resistance in the high neutron fluxes and the high temperature sodium environment encountered in I.MFBRs. However, in order to assure capability of completing the fuel cycle in a 
sodium cooled fast breeder reactor economy, the new problems introduced by LMFBR fuels must be addressed. One of the major efforts involves limiting the fuel storage requirements of early commercial breeders by providing the industry with a sound and economic fuel reprocessing capability.

One immediate concern of the overal1 LMFBR fuel reprocessing technology is the problem of selecting a safe and efficient method to remove the sodium from the fuel assemblies as well as choosing a proper way of storage before the fuels are recycled. Although a sodium pool would be desirable for storing the LMFBR spent fuels, economic considerations and the fact that the present concept of LMFBR fuel reprocessing is by the aqueous Purex process so that sodium must be removed, dictate the need of evaluating the feasibility of water pit storage for the LMFBR spent fuels. As a part of the overa11 ORNL Fuel Reprocessing Program, experiments are being conducted at WARD to determine the corrosion behavior of sodium-exposed stainless steels under various water pit storage conditions. The purpose of the present review is to assess the information currently available in the area of radiation effect on the corrosion of stainless steels in aqueous solutions, and to define additional experimental work required in providing the information pertinent to the Advanced Fuel Reprocessing Program.

\subsection{Radiation Effects and Their Influence on Corrosion}

In almost every case the overall effect of radiation on metaliic corrosion can be explained in terms of the action of the radiation on: (1) the metal itself, (2) the protective layer, or (3) the corrodant. Therefore, it is logical to discuss the subject of radiation effects on corrosion in these three areas. In practice, however, combinations of the various effects are possible.

\subsubsection{In the Metal}

The effect of nuclear radiation on materials has been extensively studied, and the results were compared and assessed in many reviews. (91-93) In the case of metals and alloys, radiation produces one or more of the following kinds of lattice disturbance: 
(1) Vacancies and interstitials.

(2) Atoms of one kind replaced by another owing to "replacement collisions".

(3) Thermal and displacement spikes.

(4) Inpurity atoms produced by transmutation or fission.

Temperature of irradiation is very important, because the disturbances can often be altered in nature or annealed out at higher temperatures.

\subsubsection{Activity Changes}

The disturbances resulting from irradiation may change the rate at which the metal reacts chemically. The changes in catalytic behavior due to irradiation have been reported. ${ }^{(94)}$ It was reported that reactor irradiation markedly increased the oxidation rate of copper until the thickness of the oxide film became greater than a few hundred Angstroms, at which stage the ionic transport controls the reaction rate and radiation had no further influence. (95)

Increased activity was also thought to be the reason for the enhanced attack suffered by stainless steels and noble metals in contact with fissioning uranyl sulphate solutions, altheligh it is possible that the weight changes observed are due to sputtering. For stainless steel, the acceleration of corrosion is found to increase with increased power density and the flow rate of solution, and appears to be greater at 250 than at $280^{\circ} \mathrm{C}$. Corrosion rates vary between 0.1 and $180 \mathrm{mils}$ per year for power densities up to $5 \mathrm{~W} / \mathrm{c} . \mathrm{c}$., velocities up to $45 \mathrm{f} / \mathrm{sec}$, and temperature of 250 or $280^{\circ} \mathrm{C} .(96,97)$ Stainless steel that is in contact with the irradiated solution but outside the radiation field does not suffer enhanced attack, implying that permanent radiation-induced chemical changes in the solution are not responsible for the effect. The alloy suffers very intense damage under fission fragment bombardment, so that increased activity of the metal seems most likely to be responsible for the increased corrosion.

\subsubsection{Dimensional Changes}

Radiation does not normally influence the bulk shape of metals, al though there are circumstances where this can occur. Volume changes can 
take place in some metals as a result of the pressure arising from the internal production of a gas where the temperature is sufficiently high to permit plastic deformation. Important examples of this are the production of gases in fissioning uranium, and the production of helium in materials such as boron and beryllium. These dimensional changes could affect corrosion rates. The surface oxide layer might crack, so allowing the corrodant to penetrate to the metal surface and increase the reaction rate. However, for stainless steels this will not be so important when the dimensional changes consists of a swelling because the change occurs very slowly and at high temperatures where corrosion rates are relatively rapid, so that there is a strong likelihood that any cracks will be rapidly filled in by more oxide. The surface film will thus be able to heal itself continually.

\subsubsection{Embrittlement}

Most metals suffer a loss in ductility due to defects and new atoms (e.g. helium) produced in the metal lattice resulting from reactor radiation. Also, in an-isotropic materials (such as a-uranium) under irradiation with fission fragments, a considerable amount of incernal stress is generated at grain boundaries due to an-isotropic growth rate. This effect was observed in reactor control-rod alloys (containing up to $2 \%$ boron in steel, titanium, or zirconium), which have been found to show enhanced attack in water at about $300^{\circ} \mathrm{C}$ after irradiation. (98) This is a form of stress-corrosion and is due to internal stress in the lattice caused by helium from the $(n, \alpha)$ reaction. For austenitic stainless steels, the ductility is one of the most sensitive to neutron-induced degradation. A fluence of about $1 \times 10^{23} \mathrm{n} / \mathrm{cm}^{2}$ (total) will reduce the total elongation such that the residual elongation is quite low, on the order of $1 \%$ (97)

\subsubsection{Phase Changes}

Phase transformations in metals resulting from radiation has been well documented. Thermodynamically stable ${ }^{(100)}$ as we1l as unstable phases (10 were reported. Different phases of the same metal or alloy have different potentials, therefore, they possess different corrosion characteristics. One example of such a change in corrosion-resistance occurs in the 
irradiation of the metastable fine-grained, single $\alpha$-phase uranium alloys (usually containing $<7 \%$ of alloying element). During irradiation, this phase transforms to a duplex structure, a change which is considered to contribute along with the embrittlement effect mentioned before to the decreased corrosion-resistance of the alloys to water at $2300^{\circ} \mathrm{C} .{ }^{(102)}$

In the case of austenitic stee 15 , neutron irradiation produces small amounts of the ferrite phase which has a lower corrosionresistance than the original austenite. However, at practical neutron dose levels (thermal-neutron flux levels are usually $10^{12}-10^{14} \mathrm{nv}$, total thermal neutron doses are usual1y no more than $10^{20}-10^{21}$ nvt) the amount of ferrite phase generated was too small to be significant, and the stainless steels have provided useful service in both pressurized and boiling-water reactors. Onty in the homogeneous aqueous reactor does stainless steel suffer enhanced attack, and this is probably due to an increase in chemical activity rather than to a phase change. However, in the LMFBRs, the total neutron doses are expected to reach about $10^{23} \mathrm{nvt}$, therefore, the effect of ferrite formation in the stainless steel cladding may be significant.

\subsubsection{In the Protective Layer}

The rate of metallic corrosion or oxidation is very often controlled by the rate of transport of ions or electrons across a protective oxide layer, which behaves like an ionic or semiconducting solid. Radiation produces the same kinds of disturbance in such solid as it produces in metals. Excitation and ionization, which are without effect in metals, are also capable of producing effects in ionic or semiconducting solids. The effect of radiation on these materials has been thoroughly reviewed.

\subsubsection{Effects on the Electric Field}

In the initial stages of corrosion or oxidation, the rate of reaction is often not controlled by simple diffusion, but the rate of transport of ions or electrons across an electric field set up in the oxide layer. A diffusion-controlled process may take over later. Irradiation may interfere with the initial stages of the reaction by increasing the electronic conductivity of the oxide layer. 


\subsubsection{Effects on Diffusion}

Since irradiation produces lattice defects such as vacancies and interstitials, it would be expected that radiation has significant effect on the protective oxide layer because the growth of oxide films is controlled almost exclusively by anionic and/or cationic diffusion. Since diffusion is a thermally activated process, temperature is a most important variable here. At low temperatures, where vacancies are not thermally mobile, the production of extra vacancies by radiation will have no effect. On the other hand, at elevated temperatures the rates of thermal production and diffusion of vacancies are sufficientiy great for diffusion to be unaffected by radiation-produced vacancies. In the intermediate temperature range, vacancies are mobile and enhancement in diffusion characteristics by radiation can be expected. A similar general observation is that those metals which have a high thermal oxidation rate will be much less prone to radiation effects than metals with a low oxidation rate.

\subsubsection{Activity Changes}

In many cases the chemical activity of the surface of metal oxides (and other semiconductor-type materials.) has been found to be markedly influenced by radiation. Changes in catalytic and absorption behavior provide the best examples of this effect. (104) An increase in chemical reactivity has been demonstrated by the enhancement of the dissolution rate of iron oxide $\left(\mathrm{Fe}_{2} \mathrm{O}_{3}\right)$ in $1 \mathrm{~N} \mathrm{HCl}$ solution after a proton dose of $10^{16}$ protons $/ \mathrm{cm}^{2}$ (particle energy $260 \mathrm{MeV}$ ). (105) Also the rate of reduction of nickel oxide (NiO) in hydrogen was enhanced by proton irradiation. (106)

\subsubsection{Phase Changes}

It has been shown that irradiation of impure anisotropic material can cause an almost complete phase transformation. The impurities provide nuclei for the new phase and without their stabilizing influence the transformation would not occur. Consequently, phase transformation in anisotropic oxide layers could affect corrosion by reducing the protectiveness of the oxide, however, experimental results show that this is not an important mechanism. 


\subsubsection{In the Corrodant}

Liquids and gases do not have a rigid structure, and the motion of component particles (molecules, ions) is rather free, so that elastic collisions of irradiating particles with the constituent particles of corrosion media have little effect on the corrosion processes. However, radiation produces changes in chemical systems through excitation and ionization. The ions, atoms, and/or [free] radicals resulting from the radiation are very active and readily react with the particles composing the medium, leading to various chemical reactions. Excitation of a molecule facilitates the occurrence of various chemical reactions by reducing the corresponding potential barriers.

Although the irradiation induced changes occurred in both gaseous and aqueous systems, the current interest is on the latter case, therefore, only the aqueous system is reviewed. The following features of the radiolysis effect on water are discussed:

(1) Irradiation of water leads to the formation of a wide variety of species such as charged molecules $\left(\mathrm{H}_{2} \mathrm{O}^{+}\right)$, excited molecules $\left(\mathrm{H}_{2} \mathrm{O}^{*}\right)$, various radicals $\left(\mathrm{OH}, \mathrm{H}, \mathrm{H}_{2} \mathrm{O}\right)$, hydrated electrons, etc. As a result a wide variety of reactions may occur in the water and it is difficult to present a complete and accurate picture of the occurring processes.

(2) The radiolysis products may be divided into two groups: a) shortlived (i.e., with a lifetime of the order of a fraction of one second) such as $\mathrm{H}, \mathrm{OH}$, and $\mathrm{HO}_{2}$ radicals in water; b) long-lived (i.e., that continue to exist for a long time after irradiation has ended) such as hydrogen peroxide in irradiated water.

(3) The radiolysis is very rapid in cases in which part of the radiolysis products are removed from the irradiated volume.

(4) Radiolysis products are formed at any point in the irradiated volume at which radiation has been absorbed.

(5) Radiolys is processes are accompanied by simultaneous recombination processes, i.e., by the formation of molecules (ions) that have been decomposed by the radiation, e.g.: 


$$
\mathrm{H}_{2} \mathrm{O} \underset{\text { recombination }}{\stackrel{\text { radiolysis }}{\rightleftarrows}} \mathrm{H}^{+}+\mathrm{OH}^{-}
$$

The formation of ammonia by irradiation of nitrogen/hydrogen mixtures may be relevant in aqueous corrosion. The $\mathrm{pH}$ will be increased (unless nitric acid formation predominates) and in systems containing steels this may have a beneficial effect. Ammonia can also be formed during the irradiation of pure nitrogen in contact with water, the mechanism being that radiolysis of the water gives hydrogen which escapes into the gas phase and then on further irradiation gives ammonia. However, ammonia in aqueous solution is oxidized by radiation, first to nitrite and then to nitrate, and also the gas-phase fixation of nitrogen to give oxides of nitrogen usually predominates over ammonia fixation, so that the formation of nitric acid is usually more important than the formation of ammonia.

\subsection{Effect of Radiation on the Corrosion of Stainless Steel in Aqueous Solution}

The corrosion resistance of stainless steel is attributed to anodic passivation, as a result of the formation of an extremely thin oxide film on the alloy surface. The high chromium content spinel double oxide formed on stainless steels is a complex nondefect oxide. Therefore, ionic transport of oxygen through this oxide film is 1 imited. The combination of a thin, elastic arid stable oxide film with absorbed oxygen or other oxidizing agents suppresses the anodic process to such an extent that the alloy becomes corrosion resistant in oxidizing media. (107)

\subsubsection{Effect of $\gamma$-Radiation}

There are two factors predominant in the case of stainless steel: the passivating effect of radiolysis products, and the changes in the absorption layer. The first factor improves the corrosion of $18 \% \mathrm{Cr}$ $8 \% \mathrm{Ni}$ steel in $1.0 \mathrm{~N} \mathrm{H}_{2} \mathrm{SO}_{4}$ at room temperature by two orders of magnitude as a result of irradiation with $\gamma$-rays from a $\mathrm{Co}^{60}$ source at a dose rate of $1.5 \times 10^{15} \mathrm{eV} / \mathrm{cm}^{3}$. $\mathrm{sec} .^{(108)}$ The data of Cartledge ${ }^{(109)}$ and Clart 1110 ; also showed that $\gamma$-radiation has a passivating effect on stainless stee 1 
in $0.1 \mathrm{~N} \mathrm{H}_{2} \mathrm{SO}_{4}$ at $85^{\circ} \mathrm{C}$. In addition, Gerasimoc and Aleksandrora investigated the electrochemical behavior of $18 \% \mathrm{Cr}-9 \% \mathrm{Ni}$ stainless steel in a nuclear reactor (in a thermal neutron flux of $10^{12}$ neutrons $/ \mathrm{cm}^{2}$. sec.) and reported that in a $0.01 \mathrm{~N} \mathrm{Na}_{2} \mathrm{SO}_{4}$ solution has no effect on the kinetics of the anodic process while in a $0.01 \mathrm{~N} \mathrm{NaCl}$ solution, radiation hinders the anodic process.

The long-term ( $1200 \mathrm{hr}$ ) experimental study of the effect of $\gamma$-radiation on the corrosion of stainless stee 1 in $3 \% \mathrm{NaCl}$ solutions conducted by Byalobzheskij ${ }^{(12)}$ provided definite evidence for the passivating effect of radiation.

\subsubsection{Crevice Corrosion}

The mechanism of crevice corrosion of stainless steel in neutral chloride solution was decribed by Byalobzheskii. (112) Briefly, the nonuniform aeration of the solution in the bulk and in the crevice produces an active/passive cell in which the surface of the metal in contact with the bulk of the electrolyte acts as a cathode while the metal in contact with the crevice (whose surface is activated because of a deficiency of oxygen) serves as an anode.

Although the rate of crevice corrosion is determined, ultimately, by the action of a concentration cell, the corrosion is generated by nonuniform aeration, i.e., by a deficiency of oxygen in the crevice and a consequent damage to the passive state of the stee1. Thus, it would be logical to reach the conclusion that radiation (which favors passivation as a result of the production of more effective oxidants in the solution) should inhibit crevice corrosion.

\subsubsection{Phase Changes}

Although irradiation produces smal1 amounts of the ferrite phase which has a lower corrosion-resistance than the original austenite in austenitic stainless steels, at practical neutron dose levels in thermal reactors the extent of the change is too small to be significant. In addition, the isotropic protective oxide film formed on the surface of stainless steels does not suffer from the radiation induced phase transformation. Consequently, stainless steels have provided useful and long-term service in both pressurized and boiling-water reactors. 


\subsubsection{Nitrogen Fixation}

There are several instances where nitrogen fixation has led to marked corrosion in practice. Nitric acid formation once caused a catastrophic failure in a high-pressure loop in the materials-testing reactor of the U.S. Atomic Energy Commission. (113) The stainless steel loop was surrounded by an air annulus into which leaked water containing copper ions. Nitrogen fixation resulted in the formation of acid which became concentrated to the fuming state by boiling. The solution dissolved away a considerable portion of the loop, and finally caused failure. Nitric acid formation may also contribute, together with ozone production, to the severe "rusting" of mild steel in the neighborhood of certain high-output electrical sources of radiation, such as some Van de Graaff generators, resonant transformers, and dynamitrons.

\subsubsection{Decomposition of Carbon Dioxide}

The formation of oxygen from carbon dioxide (114) under irradiation can lead to enhanced corrosion in high-temperature irradiations. In the case of Incone 1 and Type 446 and Type 310 stainless steel, exposure at $8 \times 10^{7} \mathrm{rads} / \mathrm{h}$ increased the rate of weight gain of the samples at $700-800^{\circ} \mathrm{C}$ and $1000 \mathrm{psi}$, probably due to the oxygen formation. A complex faliure has been recorded in which oxygen formation from carbon dioxide played a part: ${ }^{(115)}$ in these experiments, $U_{2}$ pellets clad in type 316 stainless steel ( 10 mils thick) were irradiated at $980^{\circ} \mathrm{C}$ in a flux of $1 \times 10^{13} \mathrm{nv}$ (thermal) to a burn-up corresponding to $110 \mathrm{MWd} / \mathrm{T}$. The fuel element failed, probably because the steel reacted with the oxygen available from carbon dioxide decomposition, and the cladding thus weakened gave way to the excess pressure produced by the fission-product gases. However, at lower temperatures, decomposition of carbon dioxide under irradiation does not give rise to any serious difficulties in practice.

\subsubsection{Radiolysis Products}

The radiolysis products in water resulting from radiation have little effect on stainless steels because of its fully protective adherent surface oxide films. It has been reported that stainless steels in high-purity 
aqueous systems at temperatures up to $300^{\circ} \mathrm{C}$ and at $\mathrm{pH}$ values around 10 are little affected by neutron fluxes in the region of $10^{13}-10^{14} \mathrm{nv}$ thermal. (114-117) Neither are stainless steels affected in uranyl sulphate solutions under neutron irradiation (with uranium depleted in $U^{235}$ so as to have conditions where no fission occurs) (120) Also, stainless steel is suitable as a container material for the storage of waste fission products. (121)

\subsubsection{The Integrity of the EBR-I I Fuel Pin Cladding in Water}

Prior to processing EBR-II fuel at the Idaho Chemical Processing Plant (ICPP), each fuel assembly is stored under water in a large concrete basin in the Fuel Receiving Facility (FRF). The uranium fuel pellets are sodium-bonded to 9-mil thick, Type 304L stainless steel cladding that becomes sensitized during its residence at about $500^{\circ} \mathrm{C}$ in the sodium cooled reactor. Stainless steel in the sensitized condition is known to suffer intergranular corrosion when exposed to mildly corrosive media, therefore, moderately long-term tests (122) were made at ICPP to determine if the water in the FRF is sufficiently corrosive to penetrate the Type $304 \mathrm{~L}$ stainless steel cladding on irradiated EBR-II pins during extended storage.

Five irradiated EBR-II fuel pins were placed in storage at the bottom of one of the storage basins in the FRF. These fuel pins were leak-tested periodically after placing them in a Fuel Element Leak Tester (FELT), which consisted of a stainless steel vessel with a removable lid. The vessel was connected to air and water sources by Tygon tubing running from the vessel to the surface. Prior to starting the actual test, the FELT unit containing the fuel to be tested was closed, and the vessel was purged with clean water for 24 hours to replace the contaminated water originally present. After the purge, a sample of water was obtained representing conditions at the start of the test. After seven days, the water in FELT was air sparged, then sampled. Comparison of the gamma ray spectra of these two samples for a significant increase in the concentration of radioactive nuclides indicates whether or not penetration of the cladding had occurred. 
The results of FELT tests indicate that no penetration of the fuel cladding occurred. Visual examination of the pins in the basin water indicated that no change had occurred in the external appearance of the pins. Based on the amount of $\mathrm{Cs}_{\mathrm{s}}-137$ in the water containing the clad pins, it is concluded that no significant penetration of the stainless steel cladding had occurred during two years storage in the fuel basin water at the ICPP. However, due to the fact that the fuel pins investigated have relatively low burn ups $(0.45-0.98 \%)$ and also relatively low neutron fluences ( $210^{22}$ $n v t)$, therefore, additional testing of these fuel pins is required to substantiate the preliminary results.

\subsection{Conclusion}

Mechanisms involved in the radiation enhanced metallic corrosion are reviewed with emphasis on the radiation effect on the corrosion of stainless steels in aqueous solution. Information available to date indicates that at low temperatures, radiation has little or no effect on the corrosion behavior of stainless steels. However, this conclusion does not apply directly to the reference cladding material, 20\% cold-worked Type 316 stainless steel, for the LMFBRs. Due to the corrosive sodium environment and high operating temperature of the LMFBRs, profound metallurgical and structural changes occur particularly on the surface of the cladding alloy. Due to the presence of a ferrite layer at the cladding surface resulting from sodium corrosion, the LMFBR spent fuels no longer have the corrosion-resistant stainless steel cladding. Although the preliminary results obtained on EBR-II fuel pins show that the irradiated fuel cladding did not show significant degradation during a two year storage in a water basin, these fuel pins had experienced a relatively low burn up (0.5-0.98\%) and a smal1 neutron fluence ( $210^{22}$ nvt). Consequently, additional tests are necessary to characterize the sodium-exposed and irradiated fuel cladding of the FFTF and CRBR which will have a higher burn up of about $10 \%$ and a neutron fluence of more than $10^{23}$ nvt. A similar conclusion was reached by English ${ }^{(123)}$ based on his assessinent of using water coolant for decay storage of LMFBR spent fuel elements. 


\subsection{REFERENCES}

1. P. Soo, Structural Materials for LMFBR Coolant-Boundary Components, WARD-3045T3-5, November 1972.

2. M. H. Brown, Behavior of Austenitic Stainless Steels in Evaluation Tests for Detection of Susceptibility to Intergranular Corrosion. Corrosion, Vo1. 30, No. 1, p. 1, January 1974.

3. R. Stickler and A. Vinckier, Morphology of Grain-Boundary Carbides and Its Influence on Intergranular Corrosion of 304 SS. Trans. ASM Vo1. 54, p. 362, 1961 .

4. Recommended Practice for Conducting Acidified Copper Sulfate Test for Intergranular Attack in Austenitic Stainless Steel, ASTM Designation: A 393-63, ASTM, Philadelphia, Pa.

5. L. R. Scharfstein and C. M. Eisenbrown, An Evaluation of Accelerated Strauss Testing, ASTM STP No. 369, pp. 235-239, 1963.

6. W. R. Huey, "Corrosion Test for Research and Inspection of Alloys, Trans. Am. Soc. Steel Treating, 18, p. 1126, 1930.

7. W. B. Delong, Testing Multiple Specimens of Stainless Steels in a Modified Boiling Nitric Test Apparatus, ASTM STP No. 93, p. 211-214, 1949 .

8. M. A. Streicher, Intergranular Corrosion Resistance of Austenitic Stainless Steels: A Ferric Sulfate-Sulfuric Acid Test, ASTM Bulletin No. 229, p. 77-86, 1958.

9. D. Warren, Nitric-Hydrofluoric Evaluation Test for Type 316L Stainless Steel, ASTM Bulletin No. 230, p. 45, 1958. 
10. M. A. Streicher, Screening Stainless Steels from the 240-Hour Nitric Acid Test by Electrolytic Etching in Oxalic Acid, ASTM Bulletin No. 188, p. $35(1953)$.

11. Results of Cooperative Testing Program for Evaluation of the 0xalic Acid Etch Test, ASTM Bulletin No. 195, p. 63 (1954).

12. NSMH Vol. 3, to be issued.

13. B. Weiss and R. Stickler, Phase Instabilities During High Temperature Exposure of 316 Austenitic Stainless Stee1, Met. Trans., Vo1. 3, Apri1, 1972 , p. 851 .

14. P. C. S. Wu, Corrosion Behavior of Sodium-Exposed Stainless Steels in Chioride Containing Aqueous Solutions, Topical Report, WARD-356, Westinghouse Advanced Reactors Division, Madison, Pa.

15. C. F. Cheng, Intergranular Corrosion Cracking of Type 304 Stainless Steel in Water-Cooled Reactors, Reactor Technology, 13, 310, 1970.

16. J. C. Cwynar, L. L. France, W. E. Ray, Resolution of Surface Defect Problem in Sensitized Type 304 Stainless Steel Pump Parts for FFTF, WARD 2171-55, February 1976.

17. J. C. Hodge and J. L. Miller, Stress Corrosion Cracking of Austenitic Chromium-Nickel Steels and Its Industrial Limitations, Trans. ASM, $28,25,1940$.

18. R. W. Staehle, Comments on the History, Engineering and Science of Stress Corrosion Cracking, Proceedings of Conference on Fundamental Aspects of Stress Corrosion Cracking, September 11-15, 1967, The Ohio State University, Department of Met. Engr.

19. W. E. Berry, E. L. White, and W. K. Boyd, Stress Corrosion Cracking of Sensitized Stainless Steel in 0xygenated High Temperature Water, Corrosion, Vo1. 29, No. 12, p. 451, 1973. 
20. H. L. Logan, The Stress Corrosion of Metals, page 100, John Wiley and Sons, Inc., New York (1966).

21. G. J. Bignold, Electrochemical Aspects of Stress Corrosion of Steels in Alkaline Solutions, Corrosion, Vol. 28, No. 8, p. 307, 1972.

22. R. M. Latanison and R. W. Staehle, Proceedings of Conference on Fundamental Aspects of Stress Corrosion Cracking, page 214, NACE, Houston, Texas (1969).

23. D. Warren, Chloride-Bearing Cooling Water and the Stress Corrosion Cracking of Austenitic Stainless Steel, Proceedings of the 15th Industrial Waste Conference, p. 420, 1960.

24. R. W. Staeh7e, A. Study of the Mechanism of Stress Corrosion Cracking in the Iron-Nickel-Chromium Alloy System, Final Report RF Project 1673, Contract \# AT (11-1)-1319, Rep. \#C00-1319-82, 1970.

25. T. Suzuki, M. Yamabe, and Y. Kitamura, Composition of Anolyte Within Pit Anode of Austenitic Stainless Steels in Chloride Solution, Corrosion Vol. 29, No. 1, p. 18, 1973.

26. A. A. Seys, M. J. Brabers, and A. A. Van Haute, Analysis of the Influence of Hydrogen on Pitting Corrosion and Stress Corrosion of Austenitic Stainless Steel in Chloride Environment, Corrosion Vol. 30, No. 2, p. 47, 1974 .

27. H. H. Uhlig et al., "An Evaluation of Stress Corrosion Cracking Mechanisms," Proceedings of Conference on Fundamental Aspects of Stress Corrosion Cracking, p. 86, NACE, Houston, 1969.

28. E. Dix, Jr., Trans. Am. Inst. Min. Met. Engrs., Vo1. 137, p. 11, 1940.

29. U. R. Evans, The Corrosion and Oxidation of Metals, p. 665-693, Ed. Arnold, London, 1960.

30. R. N. Parkins, J. Iron and Steel Inst., Vol. 173, p. 140, 1953. 
31. N. Petch and P. Stables, Nature, 169, p. 842, 1952.

32. H. Uhlig, Physical Metallurgy of Stress Corrosion Fracture, T. Rhodin, Editor, p. 1-16, Interscience, N.Y. (1959).

33. E. E. Denhard, "Effect of Composition and Heat Treatment on the Stress Corrosion Cracking of Austenitic Stainless Steels, "Corrosion 16, p. $359 t, 1960$.

34. T. P. Hoar and J. G. Hines, "Stress Corrosion Cracking of Austenitic Stainless Steels in Aqueous Chloride Solutions," Stress Corrosion Cracking and Embrittlement, ed. D. W. Robertson, J. W. Wiley \& Sons, p. 32, 1956.

35. "Stress-Corrosion Cracking of Austenitic Chromium-Nickel Stainless Steels," ASTi: STP 264, 1960.

36. R. W. Staehle, "A Study of the Mechanism of Stress Corrosion Cracking in the Iron-Nicke1-Chromium Alloy System, "Final Report RF Project 1673, Contract \# AT (11-1)-1319, Rep. \#C00-1319-82, February 1970.

37. D. Birchon and G. C. Boothe, "Stress Corrosion Cracking of Some Austenitic Steels as Affected by Surface Treatment and Water Composition," Proc. 2nd Inter. Congr. on Metallic Corrosion, New York, 1963, p. 33, pub. NACE, 1964.

38. D. Warren, "Chloride-Bearing Cooling Water and the Stress Corrosion Cracking of Austenitic Stainless Steel," Proceedings of the 15th Incustrial Waste Conf., p. 420, 1960. 
39. T. Shimose et al, "Stress Corrosion Cracking of Austenitic Stainless Steels in Chloride Solutions, "Trans. of the Japan Inst. of Metals, Vol. 6, p. 83, 1965.

40. P. D. Neuman and J. C. Griess, "Stress Corrosion Cracking of Type 347 Stainless Steel and Other Alloys in High Temperature Water," Corrosion Vol. 19, p. 345t, 1963.

41. W. L. Williams, "Chloride and Caustic Stress Corrosion of Austenitic Stainless Steel in Hot Water and Steam," Corrosion, Vol. 13, p. 539t, 1957.

42. K. C. Thomas, et al, "Stress Corrosion of Type 304 Stainless Steel in Chloride Environments," Corrosion Vol. 20, p. 89t, 1964.

43. B. Anderson, "Study of Stainless Steel Stress-Corrosion Cracking by Potential Measurements," Corrosion 18, p. 425t, 1962.

44. H. Koh1, "A Contribution to the Examination of Stress-Corrosion Cracking of Austenitic Stainless Steels in Magnesium Chloride Solutions," Corrosion Vol. 23, \#2, p. 39, 1967.

45. A. S. Couper, "Testing Austenitic Stainless Steels for Modern Refinery Applications," Materials Protection 8, \#10, p. 17, 1969.

46. J. C. Hodge and J. L. Miller, "Stress Corrosion Cracking of the Austenitic Chromium-Nickel Steels and Its Industrial Implications," Trans. ASM 28, p. 25, 1940.

47. R. L. Beauchamp, M. S. Thesis, Ohio State University, 1963, data listed in Reference 19. 
48. R. Franks, et a1, Symposium on Stress Corrosion of Metals, ASTM-AIME, p. 411,1944 .

49. C. Edeleanu, "Transgranular Stress Corrosion in Chromium-Nickel Stainless Steels," JISI 173, p. 140, 1953.

50. H. R. Copson, "Effect of Composition on Stress Corrosion Cracking of Some Alloys Containing Nickel," Physical Metallurgy of Stress Corrosion Fracture, ed. T.N. Rhodin, Interscience 1959, p. 247.

51. H. Suss, "Untempered Martensite Affects Stress-Corrosion of Type 410 Stainless," Metal Progress 82, p. 89, 1962.

52. D. Van Rooyen, "Review of the Stress Corrosion Cracking of Inconel 600," Corrosion, Vo1. 31, No. 9, September 1975.

53. J. E. Truman and R. Perry, "The Resistance to Stress Corrosion Cracking of Some $\mathrm{Cr}-\mathrm{Ni}-\mathrm{Fe}$ Austenitic Steels and Alloys," British Corrosion, J., Vol. 1, p. 60, 1966.

54. J. Bade and R. A. Dodd," Carbon and Nitrogen Effects in the Stress Corrosion Cracking of Austenitic Stainless Steels," the data listed in Reference 20.

55. D. Van Rooyen, "Some Aspects of Stress-Corrosion Cracking of Austenitic Stainless Steels," Proc. 1st International Congress on Metallic Corrosion, p. 309, Butterworths, 1961.

56. T. P. Hear and J. G. Hines, "The Stress-Corrosion Cracking of Austenitic Stainless Steels, Part I," JISI, 182, p. 124, 1956.

57. H. Coriou, et a1, "Sensitivity to Stress-Corrosion Cracking and Intergranular Attack of High-Nickel Austenitic Alloys," Corrosion, Vol. 22, p. $280,1966$. 
58. S. Barnartt, et al, "Stress Corrosion Cracking Mechanism in Purified 16\% Cr-20\% Ni Stainless Steels," Corrosion Science 3, p. 9, 1963.

59. H. H. Uhlig and R. A. White, "Some Effects of Alloy Composition on the Stress Corrosion Cracking of Austenitic Stainless Steels," TASM 52, p. 830, 1960.

60. H. L. Logan, The Stress Corrosion of Metals, Wiley, New York, 1966.

61. P. P. Snowdon, "Stress Corrosion of Austenitic Stainless Steels by High-Temperature Solutions and Contaminated Steam," JISI, 194, p. 181, 1960.

62. A. E. Pickett, et a1, "Development of Test to Simulate Intergranular Cracking of Non-sensitized Stainless Steel in Water Reactor Environments," Nucl. Appl. 1, p. 453, 1965.

63. C.W. Funk and G. B. Barton, "Caustic Stress Corrosion Cracking," NACE Paper SA-112-PF, October 1976.

64. D. Yakagan, J. M. Mikhailova, Intercrystalline Corrosion and Corrosion of Metals Under Stress, ed. A. J. Levin, pub. Consultants Bureau, New York, p. 179, 1962.

65. G. C. Wheeler, E. Howells, "A Look at Caustic Stress Corrosion," Design and Equipment Application Section, Power, September 1960.

66. R. K. Swandby, "Corrosion Charts: Guides to Materials Selections," Chem. Eng. 69, p. 186, 1962.

67. Preliminary Information from Research Foundation, Ohio State Univ. on USAEC Contract AT (11-1)-2018 reported in MCIC Review of Metals Technology, Corrosion and Compatibility, March 10, 1972. 
68. V.P. Sidorov, A. V. Ryabchenkov, "Corrosion Cracking of Austenitic Steels at Elevated Temperatures and Pressures," Chem. Abs. 53, pt 2 , $6029 \mathrm{~g}, 1959$.

69. E. G. Brush, "Behavior of Type 347 Stainless Steel in Sodium Hydroxide at Elevated Temperatures," KAPL-M-EGB-22, JuTy 12, 1956.

70. I. L. Wilson, et al, "The Effect of Alloy Structure, Hydroxide Conc. and Temp. on the Caustic Stress Corrosion Cracking of Austenitic Stainless Steels," Corrosion, Vol. 30, No. 4, p. 139, 1974.

71. F.W. Pement, "Caustic-Induced Stress Cracking of Stainless Stee1," USAEC Report WAPD-BT-16, December 1959.

72. E. G. Brush, "Behavior of Type 347 Stainless Steel in Sodium Hydroxide at Elevated Temperatures," KAPL-M-EGB-22, 1956.

73. B. Longson, "The Effect of Air Contaminated Sodium on Stress Specimens Made From PFR Steels and the Corrosion of These Materials and Incoloy 800 in Sodium-Sodium Hydroxide Mixtures," UKAEA TRG Memo-5668, 1971.

74. R. K. Swandby, "Corrosion Charts: Guide to Materials Selections," Chem. Eng. 69, p. 186, 1962.

75. A. A. Berk and N. F. Waldeck, "Caustic Danger Zone," Chem. Eng., p. 235, 1950 .

76. B. Longson, "Weld Embrittlement in Stabilized 2-1/4 Cr-1 Mo Steel Exposed to Sodium-Water Reaction Products at Room Temperature," UKAEA, Risley Engineering and Mater. Lab., TRG Memo 5687 (c), CFR/BM WP/P (71) 36,1971 . 
77. A. E. Durkin, "Corrosion Cracking of Martensitic Stainless Steel," Metal Progress 64, p. 73, 1953.

78. R. M. Curran et a1, "Stress Corrosion Cracking of Steam Turbine Materials," Paper presented at the Southeastern Electric Exchange, Clearwater, Florida, Apri1 21-22, 1969.

79. P. P. Snowdon, "Comparative Stress-Corrosion Behavior of Some High Alloy Stee1s," JISI 195, p. 136, 1961.

80. A. Stephenson; UKAEA report AERE-M/M-96, Harwe11, Berks (1955), "Failure of the Sodium/Steam Heat Exchanger in Liquid Metal Steam Plant Operated by Foster/Wheeler."

81. H. Coriou, et a1, "Study of $\mathrm{Cr}-\mathrm{Ni}-\mathrm{Fe}$ Austenitics for Their Corrosion Behavior from the Standpoint of Their Application in the Nuclear Field," USAEC Report, ORNL-L1-1628, 1967.

82. R. W. Staehle, "Stress-Corrosion Cracking of Fe-Cr-Ni Alloys in Caustic Environments," USAEC Report \#CO0-2018-8 (2-3).

83. M. A. Powers and H. L. Tymchyn, USAEC Report KAPL-2000-11, 1960.

84. C. T. Ward, et a1, "Intergranular Attack of Sensitized Austenitic Stainless Steel by Water Containing Fluoride Ions," Corrosion, Vol. 25, No. 9, p. 394, 1969.

85. A. S. Couper, "Minimizing Stress Corrosion Cracking of Austenitic Stainless Steel," Paper No. 47, presented at 1969 Conference, Cleveland, Ohio, NACE, March 1968.

86. ASTM-STP 264, Stress Corrosion Cracking of Austenitic Cr-Ni-Stainless Steels, 1960. 
87. A. E. Pickett, W. L. Walker, "Corrosive Effects of Coated Welding Electrode Flux and Fumes on Type 304 Stainless Steel," presented at NACE Western Regional Conference, Los Angeles, 6-8 October 1970.

88. W. E. Clark and R. E. BT anco, "Dissolution of LMFBR Fuels: Survey of the Corrosion of Selected Alloys in $\mathrm{HNO}_{3}-\mathrm{HF}$ Solutions, "USAEC Publ., ORNL-4745, 1971 .

89. A. E. Hutton, "Dissolution of HTGR Fuel" U. S. ERDA Publ., GA-A13278 (UC-77), 1975.

90. Decontamination of Plant Components for Sodium and Radioactivity: Summary Report, Specialist Meeting, Dounreay Experimental Reactor Establishment, Caithness, Scotland, Apri1 2-12, 1973.

91. G. J. Dienes and G. H. Vineyard, "Radiation Effects in Solids", 1957: New York and London (Interscience Publishers).

92. D. S. Billington and J. H. Crawford, "Radiation Damage in Solids", 1961: Princeton, N. J. (University Press).

93. A. H. Cottrell, "Effects of Neutron Irradiation on Metals and Alloys", Met. Rev. Vol. 1, Part 4, 1956.

94. H. E. Farnsworth and R. F. Woodcock, "Advances in Catalysis", Vol. 9, p. 123, 1957.

95. F. D. Varpenter and J. L. White, Proceedings of the US/UK Meeting on the Compatibility Problems of Gas-Cooled Reactors Held at Oak Ridge National Lab.s Feb. 1960, 24-26, TID-7597, 1960, Vol. 2, page 633.

96. H. F. MCDuffie, USAEC Pub1., (F-56-11-72). 
97. G. H. Jenks, HRP Civilian Power Reactor Conference Held at ORNL, May 1-2, 1957, USAEC Publ., TID-7540, 1957.

93. Survey of the Physics, Metallurgy, and Engineering Aspects of Reactor Control Materia1s, USAEC Publ., (GEAP-3183), 1959 VI-1.

99. Analysis of Structural Materials for LMFBR Coolant-Boundary Components, Compiled by P. Soo, WARD-3045 T3-5.

100. J. Fleeman and G. J. Dienes, J. App1. Physics, 1955, Vo1. 26, p. 652.

101. J. H. Kittel and S. H. Paine, Effects of Irradiation on Powder Compacts of Uranium and Some Uranium-Base A1loys, USAEC Publ., ANL-5664, 1957.

102. J. H. Kittel and K. F. Smith, Effect of Irradiation on Some Corrosion Resistant Fuel Alloys, USAEC Publ., ANL-5640, 1960.

103. PWR Program Technical Progress Report for Period August 26 to October 7, 1954, USAEC Pub1., TID-10027, 1957, p. 52.

104. H. A. Saller, Nucleonics, Vol. 14, (9), p. 86, 1956.

105. M. T. Simnad and R. Smoluchowski, J. Chem. Physics, Vol. 23, p. 1961, 1955.

106. H. T. Simnad, "The Effects of Radiation on Materials" (edited by J. J. Harwood et al.), p. 126, 1958 (Reinhold Publishing Corp.) New York.

107. R. Smoluchowski, "The Effects of Radiation on Materials" edited by J. J. Harwood et a1., p. 144, 1958: Hew York.

108. A. Aladjem, Radiation Corrosion, USAEC Publ., AEC-tr-7096, 1970. 
109. G. H. Cartledge, J. Electrochem. Soc., Vol. 104, p. 420, 1957.

110. E. S. Barnes, Geneva Conference, Vo1. 5, p. 481, 1958.

111. V. V. Gerasimov, Atomnaya Energiya, Vo1. 10, p. 164, 1961.

112. A. V. Byalobzheskii, "Radiation Corrosion" translated by A. Aladjen, AEC-tr-7096, 1970.

113. M. S. Robinson, Failure of WAPD-30 High Pressure Loop, USAEC Pub1. ID0-16338, 1957.

114. P. Harteck and S. Dondes, Geneva Conference (1958), Vol. 29, p. 415.

115. G. E. Lamale, J. E. Gates, and R. F. Dickerson, Effects of Radiation on Stainless Steel Clad $\mathrm{UO}_{2}$ Pellets in Helium or Carbon Dioxide, USAEC Publ., BMI-1335, 1959.

116. B. C. Allen et al, The Effect of Nuclear Radiation on Structural Meta1s, USAEC Pub1., REIC-5, 1958, p. 17.

117. C. R. Sutton and D. 0. Leeser, Nucleonics, 1954m 12. (9), p. 8.

118. L. Schieb, USAEC Pub1., ORNL-1915, 1954, p. 48.

119. A. P. Larrick, Comparison of the Corrosion of Carbon Steel, Stainless Steel, Inconel X, Monel, and Stellite in the KER Mock-up Tubes with Out of Reactor Loops, USAEC Pub1., HW-63872, 1960.

120. J. J. Stabbs and A. J. Swallow, Met. Rev. 1962, Vol. 7, No. 25, p. 95.

121. F. Hittman and A. 0. KuhT, Initial Study on the Effect of High Level Gamma Radiation on Corrosion of Metals, USAEC Pub7., BNL-2257, 1956.

122. C. A. Zimmerman and D. W. Rhodes, IN-1331, 1969.

123. J. L. English, Considerations for Use of Water-Coolant for the Decay Storage of Liquid Metal Fast Breeder Reactor Spent Fuel Elements A Literature Survey, ORNL/TM-5762, Apri1 1977. 


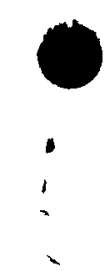

1

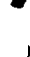

.'

,

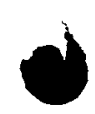


ORNL/TM-631 1

Dist. Category UC-79c

INTERNAL DISTRIBUTION

1. J. T. Bell

2. M. Bender

3. M. R. Bennett

4. E. D. Blakeman

5. R. E. Blanco

6. J. 0. Blomeke

7. R. Bl umberg

8. W. D. Bond

9. B. F. Bottenfield

10. E. C. Bradley

11. N. C. Bradley

12. R. E. Brooksbank

13. K. B. Brown

14-18. W. D. Burch

19. D. D. Cannon

20. J. M. Chandler

21. W. E. Clark

22. L. T. Corbin

23. D. A. Costanzo

24. R. M. Counce

25. D. J. Crouse

26. B. F. Crump

27. J. P. Drago

28. B. C. Duggins

29. D. E. Dunning

30. J. H. Evans

31. M. J. Feldman

32. D. E. Ferguson

33. L. M. Ferris

34. S. D. Lloyd

35. J. Garin

36. J. H. Goode

37. N. R. Grant

38. W. S. Groenier

39. W. R. Hamel

40. D. C. Hampson

41. B. A. Hannaford

42. W. 0. Harms

43. J. N. Herndon

44. R. M. Hill

45. W. D. Holl and
46. D. E. Horner

47. A. R. Irvine

48. J. D. Jenkins

49. R. T. Jubin

50. P. R. Kasten

51. A. D. Kelmers

52. L. J. King

53. J. Q. Kirkman

54. J. A. Klein

55. C. E. Lamb

56. B. E. Lewis

57. M. H. Lloyd

58. D. K. Lorenzo

59. A. L. Lotts

60. J. C. Mailen

61. A. P. Mal inauskas

62. D. L. Manning

63. L. Maya

64. J. D. McGaugh

65. L. E. McNeese

66. R. P. Milford

67. A. D. Mitchell

68. J. G. Morgan

69. J. M. Morrison

70. E. L. Nicholson

71. E. D. North

72. J. H. Pashley

73. F. L. Peishel

74. H. Postma

75. R. H. Powell

76. R. H. Rainey

77. G.W. Renfro

78. J. E. Rushton

79. W. F. Schaffer, Jr.

80. C. D. Scott

81. T. Shapiro

82. B. B. Spencer

83. R. G. Stacy

84. M. J. Stephenson

85. J. G. Stradley

86. D. W. Swindle 
87. 0. K. Tallent

88. D. B. Trauger

89. W. E. Unger

90. V. C. A. Vaughen

91. B. L. Vondra

92. B. S. Weil

93. T. D. Welch

94. M. E. Whatley

95. J. R. White

96. R. G. Wymer

97. 0. 0. Yarbro

98. S. Beard (consultant)

99. Manson Benedict (consultant)

100. L. Burris, Jr. (consultant)

101. A. B. Carson (consultant)

102. G. R. Choppin (consultant)
103. E. L. Gaden, Jr. (consultant)

104. C. H. Ice (consul tant)

105. W. H. Lewis (consultant)

106. A. Schneider (consultant)

107. L. E. Swabb, Jr. (consul tant)

108. M. J. Szul inski (consul tant)

109. J. S. Theilacker (consul tant)

110. K. D. Timmerhaus (consulant)

111. A. K. Williams (consul tant)

112-113. Central Researh Library

114. ORNL - Y-12 Technical Library

Document Reference Section

115-115. Laboratory Records

117. Laboratory Records, ORNL RC

118. ORNL Patent Office

119. Nuclear Safety Information Center

\section{EXTERNAL DISTRIBUTION}

120. Director, Reactor Division, DOE-ORO

121-122. Director, Division of Nuclear Fuel Cycle and Production, DOE, Washington, D. C. 20545

123-124. Director, Division of Reactor Research and Development, DOE, Washington, D. C. 20545

125. M. L. Bleiberg, Westinghouse Electric Corporation, Advanced Reactors Division, Waltz Mill Site, P. 0. Box 158, Madison PA 15663

126. Duane E. Clayton, Battelle Pacific Northwest Laboratory, P. 0. Box 999, Richland, WA 99352

127. Martin Friedland, Gulf + Western Advanced Development and Engineering Center, 101 Chester Road, Swarthmore, PA 19081

128. Jerry M. Friedman, Sandia Laboratories, P. 0. Box 5800, Albuquerque, NM 87115

129. Frank J. Jones, Bechtel Corporation, P. 0. Box 3965, San Francisco, CA 94119

130. B. F. Judson, Vice President and Manager, GEUMCO-Engineering, 175 Curtner Avenue, Mail Code 858, San Jose, CA 95125

131. R. S. Karinen, Programmed and Remote Systems Corporation, 3460 Lexington Avenue, St. PauT, MN 55112

132. Robert H. Karlsson, Rockwell International, Atomics International Division, Rocky Flats Plant, P. 0. Box 464, Golden, C0 80401

133. R. E. Mullen, Aerojet Manufacturing Company, 601 Placentia Avenue, P. 0. Box 4210, Fullerton, CA 92634

134. D. E. Wood, Kaman Sciences Corporation, 1500 Garden of the Gods Road, P. 0. Box 7463, Colorado Springs, C0 80933

135. Research and Technical Support Division, DOE-ORO

136-344. Given distribution as shown in TID-4500 under UC-79c, Fuel Recycle Category (Applied) 